\title{
German Verse from the 12th to the 20th Century in English Translation
}


German Verse from the 12th to the 2oth Century in English Translation 


\section{IIIIUNC}

From 1949 to 2004, UNC Press and the UNC Department of Germanic \& Slavic Languages and Literatures published the UNC Studies in the Germanic Languages and Literatures series. Monographs, anthologies, and critical editions in the series covered an array of topics including medieval and modern literature, theater, linguistics, philology, onomastics, and the history of ideas. Through the generous support of the National Endowment for the Humanities and the Andrew W. Mellon Foundation, books in the series have been reissued in new paperback and open access digital editions. For a complete list of books visit www.uncpress.org. 


\section{German Verse from the 12th to the 2oth Century in English Translation}

J.W. THOMAS

UNC Studies in the Germanic Languages and Literatures

Number 44 
Copyright (C) 1963

This work is licensed under a Creative Commons CC BY-NC-ND license. To view a copy of the license, visit http://creativecommons. org/licenses.

Suggested citation: Thomas, J. W. German Verse from the 12th to the 2oth Century in English Translation. Chapel Hill: University of North Carolina Press, 1963. DOI: https://doi.org/10.5149/9781469658469_ Thomas

Library of Congress Cataloging-in-Publication Data

Names: Thomas, John Wesley.

Title: German verse from the 12th to the 2oth century in English translation / by John Wesley Thomas.

Other titles: University of North Carolina Studies in the Germanic Languages and Literatures ; no. 44.

Description: Chapel Hill : University of North Carolina Press, [1963] Series: University of North Carolina Studies in the Germanic Languages and Literatures.

Identifiers: LCCN 64063239 | ISBN 978-0-8078-8044-9 (pbk: alk. paper) | ISBN 978-1-4696-5846-9 (ebook)

Subjects: German poetry - Translations into English.

Classification: LCC PD25 .N6 NO. 44 
To

\section{PHILIP ALLISON SHELLEY}

whose seminar on the German Lyric twenty-five years ago provided the initial stimulus for this work. 



\section{PREFACE}

The purpose of this anthology is to make available to the reader who knows no German a representative selection from eight centuries of German poetry, together with such explanatory comment as may add to his comprehension and enjoyment of it. The reader will, of course, realize that verse-translation - the attempt to reproduce in a different language the content, mood, style, and structure of a poem - can be successful only to a limited degree. However, should he lend a sympathetic and creative imagination to his reading of these translations, he may, nevertheless, feel some of the beauty of the originals.

In preparing this work I have become indebted to several of my friends and colleagues and would like to express here my appreciation to Professors Faulkner, Guinn, Rouse, Rudolph and Van Scyoc, of the University of Arkansas, for valuable suggestions as to the improvement of individual translations. I am particularly grateful to Professor B. Q. Morgan, of Stanford University, and to Professor and Mrs. Hans-Joachim Lang, of Tübingen University, for having advised me on almost the entire manuscript. I can only regret that my limitations as a poet frequently made it impossible for me to benefit fully from their critical discernment.

There is, of course, another group of scholars to whom I am indebted, those from whose writings I have drawn for many of the explanatory remarks which accompany the translations. However, since a list of their names and works would make this preface unduly long, I trust I may be permitted to confine myself to a general expression of thanks for the use of their ideas.

Four of the translations which appear in the anthology were done by colleagues and former colleagues: Prof. Faulkner (Schiller's "Lament"), Prof. Van Scyoc (Günther's "Farewell Aria"), Dr. Iggers (Brentano's "Your Song"), and Dr. Allen (George's "Path Of God To Us Is Opened"). The rest were done by myself. 



\section{CONTENTS}

I. THE MINNESINGERS .................. 1

DIETMAR VON AIST . . . . . . . 3

Farewell Summer's Bliss. . . . . 3

A Lady Stood Alone . . . . . . . 4

Still Sleeping, Handsome Knight . . 4

Yonder On The Linden Tree . . . 5

HEINRICH VON MORUNGEN . . . 5

Daybreak . . . . . . . . 6

The Haughty Lady . . . . . . . . 7

Love After Death . . . . . . . . 8

Love's Joy. . . . . . . . . . . . 8

WOLFRAM VON ESCHENBACH . . 9
Dawn Song . . . . . . . . . 10

WALTHER VON DER VOGELWEIDE 11

Welcome And With All Good Cheer 12

When From The Grass The Meadow

Flowers Spring . . . . . . 13

Under The Linden . . . . . . . . 14

I Saw The World . . . . . . . . 15

Power Of Love. . . . . . . . . . 16

NEIDHART VON REUENTHAL • . 16

Spring Song . . . . . . . . 17

May Song . . . . . . . . 18

Dance In A Village Tavern . . . 18

II. THE BAROQUE POETS . . . . . . . . . . . . . . . . . . . 21

PAUL GERHARDT . . . . . . . 22

Now Sleep Beneath Night's Shadow 23

Go Forth, My Soul . . . . . . . 24

Oh Sacred Head . . . . . . . . 25

PAUL FLEMING . . . . . . . . 25

Ode To Myself . . . . . . . 26

It Is In Vain The Sorrow . . . . . 26

Love's Fire . . . . . . . . . . . 28

On The Death Of A Child . . . . 28

ANDREAS GRYPHIUS . . . . . 29

Vanitas Mundi . . . . . . . . 29
Evening . . . . . . . . 30

To Eugenie . . . . . . . . . . 31

JOHANNES SCHEFFLER. . . . . . 31

Jesus, God Of Love . . . . . . . 32

Selections from The Cherubic Wanderer . . . . . . . . 33

CHRISTIAN HOFMANN VON HOFMANNSWALDAU . . . . . . 33

Seiisual Joy . . . . . . . . . 34

The Imperishable . . . . . . . 35

Where Are The Hours . . . . . 36

The World . . . . . . . 37 
CHRISTIAN GÜNTHER . . . . . . 39

A Madrigal To His Magdalis . . . 40

Farewell Aria . . . . . . . . 40

A Student Song . . . . . . . 41

To Leonore . . . . . . . . . . 43

FRIEDRICH KLOPSTOCK . . . . . 44

The Rose Wreaths . . . . . . . . 45

The Youth . . . . . . . 45

The Early Graves . . . . . . . . 46

Summer Night . . . . . . . . . 47

My Grove . . . . . . . . 47

MatThias ClaUdius . . . . . 48

IV. GOETHE

The Song of Mohammed . . . . . 58

Prometheus . . . . . . . 60

The Son Of The Muses . . . . . 62

Vacillation ........ 63

Love . . . . . . . . . . . 63

Wanderer's Night Song I . . . . . 64

Wanderer's Night Song II . . . . . 64

To The Moon . . . . . . . . . 65

Human Limitations . . . . . . 66

V. SCHILLER AND HÖLDERLIN

FRIEDRICH SCHILLER . . . . 73

Poesie . . . . . . . . 73

The Strange Maiden . . . . . . 74

The Maiden's Lament. . . . . . . 75

Lament . . . . . . . . . 75

Evening . . . . . . 76

Mountain Song . . . . . . 77

Three Songs from William Tell $\quad$. 78
May Song . . . . . . . . . . 49

The Mother By The Cradle . . . . 50

Death And The Girl . . . . . . . 51

A Song To Be Sung Behind The Stove 51

Christiane . . . . . . 52

Death. . . . . . . . 53

LUDWIG HÖLTY. . . . . . 53

May Song . . . . . . 53

To The Evening Star . . . . . . . 54

To A Violet . . . . . . . . . . 55

Harvest Song . . . . . . 55

The Cup Of Forgetfulness . . . . . 56

The Harper's Song . . . . . . . . 67

Song Of Mignon I . . . . . . . 68

Song Of Mignon II $\ldots \ldots \ldots$

Admonition . . . . . . . . . 69

The Presence Of The Loved-One . . 69

The Quiet Of The Sea. . . . . . . 70

A Happy Crossing . . . . . . . . 70

Blissful Longing . . . . . . . 71

Permanence In Change . . . . . 71

VI. THE ROMANTIC POETS . . . . . . . . . . . . . 85

NovALIS ........ 86

Must Morning Ever Return . . . . 88

I Shall Pass Over 87

Death. . . . . . . . . 89 
Maria. . . . . . . . . . . 89

The Hermit's Song . . . . . . . . 89

CLEMENS BRENTANO . . . . . . 90

Evening Serenade . . . . . . 91

Lullaby . . . . . . . . . . . . . 91

Your Song . . . . . . . . . . . 92

The Forest . . . . . . . . . . . 92

Evening Song . . . . . . . 93

LUDWIG UHLAND . . . . . . . . 94

The Chapel . . . . . . . . . . . 94

Spring Faith . . . . . . . . 95
The Innkeeper's Daughter . . . . 95

The Smith . . . . . . . . . . . 96

The Walk To The Sweetheart . . 97

The Castle By The Sea . . . . . . 97

JOSEPH VON EICHENDORFF . . . 98

Longing . . . . . . . . . . . 99

The Broken Ring . . . . . . . 100

A Moonlit Night . . . . . . . 100

The Evening . . . . . . . . 101

A Conversation In The Forest . . . 101

The Hermit . . . . . . . . . . 102

VII. THE POST-ROMANTIC GENERATION . . . . . . . . . . 104

FRIEDRICH RÜCKERT . . . . 105

Barbarossa . . . . . . . . 106

O Stop With Me . . . . . . . 107

My Soul, My Heart . . . . . . 108

Ghasel ......... 108

AUgust von Platen. . . . . 109

The Pilgrim Before St. Just . . . . 109

The Grave In The Busento . . . . 110

Remorse . . . . . . . . . 111

Tristan . . . . . . . . . . 112

HEINRICH HEINE . . . . . . . 112

Belshazzar . . . . . . . . . 113

Poems From Lyrical Intermezzo . . 114

In That Exquisite Month Of May . 114

From Out My Tears Of Sorrow . . 115
O When I Look Into Your Eyes . . 115

The Lotus Flower Is Troubled . . 115

A Lonely Pine Is Standing . . . 116

I Sat By The Paling Seashore . . . 116

Nikolaus lenaU. . . . . . . 117

Prayer . . . . . . . . . . 118

Sedge Songs . . . . . . . . . 118

The Three . . . . . . . . . 120

EDUARD MÖRIKE . . . . . . 121

Weyla's Song . . . . . . . . 121

Seclusion . . . . . . . . . 122

Soul, Think Of This . . . . . 122

September Morning . . . . . 123

Midnight . . . . . . . . 123

To An Aeolean Harp . . . . . 124

VIII. POETS OF REALISM . . . . . . . . . . . . . . . . . 125

FRIEDRICH HEBBEL . . . . . 126

Revelation. . . . . . . . 127

Requiem ......... . 127

A Picture Of Summer . . . . 128

A Picture Of Fall. . . . . . . 129

The Individual And The Universal . 129
THEODOR STORM . . . . . . 129

The Heath. . . . . . . . . . 130

Song Of The Gypsy Girl . . . . 131

The City . . . . . . . . . 131

May ........... . 132

July . . . . . . . . . 132 
The Seashore . . . . . . . . 132

GOTTFRIED KELLER . . . . . 133

Summer Night . . . . . . . . . 134

Winter Night . . . . . . . 135

Illusion And Truth . . . . . . . 135

Time Does Not Pass . . . . . . 136
CONRAD FERDINAND MEYER . . 137

Schiller's Burial . . . . . . 138

The Roman Fountain . . . . . 138

The Sower's Song . . . . . . . 138

At Heaven's Gate . . . . . . . 139

Sundays . . . . . . . . . 139

IX. THE MODERN POETS . . . . . . . . . . . . . . . . . 141

FRIEDRICH NIETZSCHE .. . . 142

Ecce Homo . . . . . . . . . 143

Venice . . . . . . . 143

The Drunken Song . . . . . . . 144

The Sun Sinks . . . . . . . . . 144

The Wanderer And His Shadow. . 146

STEFAN GEORGE . . . . . . . 146

Come To The Park . . . . . . . 147

The Hillside Where We Wander Lies

In Shadows . . . . . . . . . 147

Path Of God To Us Is Opened . 148

My Child Came Home . . . . . . 148

Windows Where I Once With You . 149

HUGO VON HOFMANNSTHAL . 150

Early Spring . . . . . . . 150

Ballad of The Outward Life . . . . 151
Poem In Terza Rima . . . . . . 152

Some Indeed Below The Deck Must Perish. . . . . . . . . 153

RAINER MARIA RILKE . . . . . 153

Solitude. . . . . . . . . . 154

The Knight . . . . . . . . . . 155

Autumn Day . . . . . . . . 155

Autumn . . . . . . . . 156

On The Brink Of Night . . . . . 156

Song Of The Sea . . . . . . . . 157

Selections From Sonnets To Orpheus 157

Sonnet I . . . . . . . . . . . . 158

Sonnet II . . . . . . . . . . . . . 158

Sonnet V . . . . . . . . . . . 158

Sonnet XIV . . . . . . . . . . 159

Sonnet XIX . . . . . . . . . . 159 


\section{THE MINNESINGERS}

The search for the origins of the German literary tradition leads back as far as the massive migrations of the German tribes which took place from the third to the sixth century A.D. While there is abundant evidence that this, the heroic period of German literature, produced a great wealth of epic and lyric verse, none of it has been preserved. The earliest manuscript extant, that of the epic poem, "The Song of Hildebrand," dates back no further than the second decade of the ninth century, although the poem itself is much older. "The Song of Hildebrand" was followed by translations from Greek and Latin, Christian didactic verse and prose, and finally by other epic poems, but it was not until the time of the minnesingers, beginning about 1170 , that lyric poetry was first recorded and preserved.

The minnesongs, or love songs, although coming at the beginning of the recorded history of German lyric poetry, represent by no means the beginning, but rather the apex of a literary development. They were highly sophisticated poems, set in an intricate and polished form, and composed for a sophisticated society. The public to which the minnesongs were sung consisted of the higher strata of feudal society, a leisure class which felt economically, politically, and religiously secure. The agrarian economy of feudalism had reached its point of greatest perfection; the Holy Roman Empire was, as a political system, in its golden age; and the dualism of flesh versus spirit, which had entered German life with Christianity, had been at least temporarily reconciled. The wellordered society of knights, ladies, and nobles that rode the crest of this cultural renascence insisted above all on moderation and good manners, by which was meant the meticulous observance of social forms. And moderation and manners became criteria which determined both content and structure of the minnesong.

The German culture of the twelfth century had been greatly enriched and broadened by the Crusades. Contact with the older civilizations of the Near East and with France and Italy brought an increased refinement and stirred the imaginations of singers and listeners. The wars for the Holy Land also showed how the pagan virtues of bravery and loyalty could be used in the cause of Christianity. The result was the evolvement of the code known as chivalry, a code of conduct which combined the enjoyment of earthly pleasures with the service of God, which united pagan and Christian ideals. One aspect of chivalry, however, the idealization of woman and of love, had its origins, not in 
the Crusades, but in the worship of the Virgin Mary. The adoration of Mary had long been a source of lyrical inspiration, and under the code of chivalry this adoration was often secularized to have as its object the high-born, married lady, who, like the Virgin, must be worshipped from afar. It should not be assumed, however, that all, or even most, of the minnesongs were Platonic in nature. Many of the best sing of the joys and fears of requited and often illicit love. The position of woman is not degraded in these songs and love itself is still idealized, for the songs were for the entertainment of a cultured society which could enjoy flirtatious and even risqué themes but would not tolerate what was openly obscene.

The immediate antecedents of the minnesong were the folksongs, particularly of Austria, and the lays of the Provençal troubadors. The former were probably quite simple in structure, while the latter were rather complicated. Both accentuated form, for it was a culture of formalized conceptions whose highest achievement was the building of Gothic cathedrals. The minnesong developed many strophic forms, for each poet took pride in the number and originality of the "tones" that he had invented. Most "tones" of the earlier period follow a single basic pattern. The unit is a stanza which is divided into two parts: the "rising song" and the "falling song." The former is in turn made up of two equal and parallel parts, called Stollen, making the stanza tripartite. The "falling song" is usually shorter than the "rising song," but longer than the individual Stollen.

The composers of the minnesongs, the minnesingers, were the aristocratic successors of the warrior-bards of the migrations and the Vaganten, the wandering professional minstrels, who followed them. The minnesingers were often members of the lesser nobility and men of considerable education, a part, therefore, of that genteel and symmetrical culture which their songs reflected.

The classical period of the minnesong extended approximately from 1170 to 1220 , but the minnesong remained the dominant lyrical form until the fifteenth century. 
Dietmar von Aist, an Austrian knight, was one of the earliest of the minnesingers and is one of the most interesting to study because of the definite development which his verse reveals. The early poems with their parallel, often impure rhymes closely resemble the folksongs; the later ones have pure rhyme and a more intricate rhyme pattern. The love he sings of is naïve rather than sophisticated, and his women are not the distant, unresponsive, and unattainable ladyloves of many of the later minnesongs. They are passionate and yearning creatures who often appear as the narrators of Dietmar's songs. Such poems, in which a woman expresses her sentiments in a monologue, an admonition to a lover, or a message to her knight, became very popular among the minnesingers and were known as Frauenstrophen, lady's verses. Another popular type of minnesong which first appeared in German in the verse of Dietmar was the Wechsel or alternating song, in which a stanza is sung by the lady and a response is sung by the knight. Often the two are represented as not being in each other's presence at all, but separated by great distances. A third type of minnesong which Dietmar composed is the Tagelied, or dawn song, which describes the awakening and parting of two lovers at break of day. Dietmar awakens them gently by the singing of birds and the sounds of nature but his successors have them more rudely awakened by the watchman on his morning rounds.

\section{FAREWELL SUMMER'S BLISS}

(So wol dir, sumerwunne)

The lady says farewell to summer and to her husband who is departing on a long journey. The alliteration in this poem reveals its close connection to the old Germanic epic. The rhymes are pure as far as vowels are concerned, but the consonant rhyme is still imperfect.

Gay summer's bliss, goodbye!

The birds' sweet song has died, the linden's leaves are gone, the fading year beyond will make these fair eyes weary. My love, hear this entreaty: all other charms avoid, and other arms. The moment that you met me your manly form impressed me, I thought you wondrous fair so, husband, dear, beware! 


\title{
A LADY STOOD ALONE
}

(Es stuont ein frouwe alleine)

The objects of nature, especially birds and flowers, appear frequently in Dietmar's verse, often with symbolic significance. The impure rhyme identifies the poem as another of his early productions.

\author{
A lady stood alone \\ and looked out on the plain \\ and waited for her love; \\ she saw a falcon high above. \\ "Lucky falcon there on high! \\ Whither you wish you fly; \\ you choose from the forest trees \\ whichever one you please. \\ So I too have done: \\ I chose myself a man, \\ my two eyes did agree. \\ But charming women envy me. \\ Oh, why do they set their snares? \\ I never wanted a lover of theirs."
}

\section{STILL SLEEPING, HANDSOME KNIGHT}

(Slâfest du, friedel ziere)

This dawn song well illustrates the painstaking symmetry which the minnesingers gave their verses. The first eight lines make up the rising song with its two Stollen of equal length; the last four lines form the falling song. In the first Stollen, in which a lady speaks, the word "sleeping" in the first line parallels "Awake! Awake!" in the second line, while objects of nature, the birds and the linden tree, appear in parallel in the third and fourth lines. These two symbols of happiness contrast with the sorrow which is implied in the first half of the Stollen.

In the second Stollen (lines five to eight), in which a knight is speaking, it will be noted that the first two lines parallel the first two lines of the first Stollen. "I slept gently" answers "Still sleeping?" and "you give the alarm" corresponds to "Take flight!" The first two lines of the second Stollen (lines five and six) contrast with each other as "love" contrasts with "sorrow" in the following line. Both emotions are resolved in the concept of service which is presented in the last line of the second Stollen (line eight).

The concluding four lines, the falling song, present the real theme of the poem, which is the lament of the lady at the departure of her lover. The rising song merely sets the scene for this outpouring of sorrow. Similar symmetrical patterns will be observed in other minnesongs. 
"Still sleeping, handsome knight?

Awake! Awake! Take flight!

A bird in all its finery warns us from the linden tree."

"I slept gently on your arm, and now, sweetheart, you give the alarm; but love must have its sorrow too, what you command I'll quickly do." The lady then began to moan, "You ride and leave me all alone. When will you ever return to me? With you my joys and pleasures flee."

YONDER ON THE LINDEN TREE

(Uf der linden obene)

This alternating song, which voices first the thoughts of the knight and then those of his far-away sweetheart, belongs to Dietmar's later poems. The roses are used as symbols of love.

"Yonder on the linden tree there sang a merry, little bird. It's voice rang out at the forest's edge and then my heart, by memory stirred,

returned to a place that it once knew. I saw the roses gently blow; they bring a host of thoughts about a certain lady that I know." "It seems at least a thousand years since in my lover's arms I lay;

and I am not to blame that he has left me now for many a day. Since then I've seen no flowers bloom and heard no bird's enchanting song, since then my joy has been short-lived, my pain and sorrow all too long."

The Thuringian Heinrich von Morungen was a poet of great originality and imagination. Unlike Dietmar, he was more strongly influenced by the songs of Provence than by folksongs. This influence is seen partly in his preference for dactyls and partly in the sophistication and ingenuity of his verse. He sings of courtly love, and his dominant theme, the lament of the knight over the heartlessness of the lady, became one of the chief subjects of the later minnesingers. Heinrich often borrows imagery from nature and reflects its ever- 
changing moods in verse which can change quickly from darkness to joy, from passion to torment.

It is probable that Heinrich made a journey to the Holy Land at about the turn of the century.

\section{DAYBREAK}

(Owê, sol aber mir iemer mê)

In this dawn song and alternating song the knight and lady are far apart and are recalling in alternating monologues the ecstasy and sorrow of their parting. The original is one of the most beautiful love lyrics of European literature. It will be noticed that the closely-knit form of the early minnesong is changing to a stanzaic structure.

\section{“Oh! Oh!}

Will nevermore the glow of that fair form as white as newly fallen snow come to me through the night? The sight deceived my eyes, I thought I saw arise the bright moon in the skies. Then came the dawn!"

"Oh! Oh!

And will he never know the daybreak here again, nor watch the darkness go, nor share my sorrow when I cry: 'Alas, ' $t$ is day!'? That he, too, used to say when he beside me lay. Then came the dawn!"

\section{"Oh! Oh!}

A thousand times, it seems, she kissed me as I slept, and, till I left my dreams, how bitterly she wept. But then I knew how best to put her tears to rest; she drew me to her breast. Then came the dawn!" 


\section{"Oh! Oh!}

So many times has he seen more than was his due and quite uncovered me; he wanted just to view this form all bare and bright. I wondered that my knight so much enjoyed the sight. Then came the dawn!"

\section{THE HAUGHTY LADY}

\section{(Sach ieman die frouwin)}

In most of the great number of lover's laments which the minnesingers produced, a clever playing with sentiment is apparent. In those of Heinrich, however, the emotion is stronger and more genuine, often violent. The primitive Germanic lust for revenge shows through the courtly façade in the last lines of this poem. The stanzas are not directly continuous in time, but represent separate stages of an unhappy love affair.

What lady is she whom one may see in the window there? Her beautiful face and airy grace can free me from care, for she glows with the warmth of the rising sun in the morning's early light.

Long was she hidden from sight and dark was the night, but now the world is all fair.

If someone is here whose reason is clear in this hour of gloom, seek her who bereft me of beauty and left me to sorrow and doom, and entreat her to hasten and soothe my grief while life and breath remain.

For torments of passion and pain

I cannot restrain are driving me to the tomb. 
Then clearly make known

my fate on the stone

that covers my grave.

Tell of beauty adored

and a lover ignored,

that the knight or the knave

as he passes may learn from my woeful tale

of love that burns and rends.

There he may read how she sends

cold death to her friends,

so cruelly does she behave.

\section{LOVE AFTER DEATH}

\section{(Vil sûze senfte tôterinne)}

This is one of the earliest German poems to employ pentameter. The pentameter line which appears in the alternate verses is the result of Heinrich's adaptation of the Provençal ten-syllable line.

Oh sweetest, tenderest assassin, why slay your love and me and cast aside the hopes and gentle ties that fasten our hearts, and just to please your woman's pride? Oh can you dream that, having killed me, you then will wander free of my design? No! No, so full your love has filled me that evermore your soul is wed to mine. Though here my heart may suffer sorrow from one who lies so near it, I tell you, soon, perhaps tomorrow, my soul will love and serve you there, a light and laughing spirit.

\section{LOVE'S JOY}

(In sô hôhir swebinder wunne)

Early Germanic poetry had no rhyme and depended for its lyrical quality on two devices: regular rhythm and regular alliteration. With the coming of rhyme alliteration became less important, but it did not disappear. Heinrich's irregular, but very effective use of alliteration is the source of much of the lyrical quality of such poems as this. 
On such a cloud of joy as this

my soul has never sailed so high before.

I hover as on wings of bliss

with thoughts of only her whom I adore, because her love unlocked the door which leads into my inmost heart and entered there for evermore.

All other raptures that remain with this great happiness cannot compare. Let earth and sky and wood and plain with me a time of soaring gladness share. For, filled with hope and freed from care, and thrilled by dreams of ecstasy, my joy is more than I can bear.

What all entrancing words were those which sounded, oh so sweetly, in my ear! And what a gentle pain arose to sink with joy into my bosom here, where such delights did then appear, such loving overcame me so, that from my eye there fell a tear.

How happy was that sweet event! How blissful was that hour, the fading night, when lovely lips gave their consent and spoke the word which made my heart so light that I must tremble as in fright.

And even now love's power is so, I know not how to praise her right.

WOLFRAM VON ESCHENBACH (c. 1170 - c. 1220)

Wolfram von Eschenbach was a Bavarian squire who spent most of his adult life at the court of Hermann of Thuringia. Today he is known primarily for his epic poetry: Titurel, Willehalm, and particularly the great masterpiece of the German Middle Ages, Parzival. In the thirteenth century, however, Wolfram's fame rested chiefly on his minnesongs, of which, unfortunately, only eight have survived. He was perhaps the most profound and versatile poet of his time, but his peculiar, acrid humor, his play with strange pictures and symbols, and his abruptness of expression made for a difficult style, to which his contemporaries sometimes objected. Even his lyric poetry occasionally has a darkness and obscurity, which, however, is often animated by a spirited sensuousness. 
Perhaps because he came from the lowest stratum of nobility, Wolfram reflects in his verse more earthy vigor and less conventional manners than most of the minnesingers.

\section{DAWN SONG}

(Sîne klâwen durh die wolken sint geslagen)

The person of the watchman in German literature was first introduced into the dawn song in this poem, which consists of a dialogue between the watchman and a lady. Wolfram's tendency toward vulgarity is seen, not in the favors which his lady tenders her lover, but in the intimation that the watchman may have fared equally well.

"Dawn strikes its claws through massive clouds and mounts in flight.

It rises with relentless power

and with it draws

the graying shadows of the night.

I see the day, which at this hour

will steal the pleasure of the man

whom I admitted fearfully.

I'll get him out now, if I can:

his stately bearing must have blinded me."

"The song you sing,

oh watchman, takes my joy away

and makes more grievous my lament.

The news you bring

each morning at the break of day gives only sorrow and discontent.

Such words I do not care to hear, so hold your tongue and let us be, and I'll reward you, never fear, if my dear love remains awhile with me."

"He still must go, sweet lady, say goodbye, that he may leave as promptly as he came, and later show his love for you more stealthily, preserve his life and his good name. He trusted in my faithfulness to get him safely forth from here; the night has passed when your caress and kisses bought my aid to bring him near." 
"Sing what you will,

oh watchman, sing, but let him stay,

who brought his love and here found mine.

Your rough words fill

us always with a sad dismay.

Before the morning star can shine

upon this knight who visits me,

while still no rays of sunlight part

the night, you make him rise and flee

from my bare arms, but never from my heart."

But still the clear,

bright rays the sun cast overhead

and the warning watchman's rude request

caused her to fear

for the gallant knight who shared her bed:

she pressed him closely to her breast.

And yet the knight was strong and brave,

despite the watchman's song above;

their warm and tender parting gave

them kisses (and much more) as spoils of love.

WALTHER VON DER VOGELWEIDE (c. 1170 - c. 1230)

In the verse of Walther von der Vogelweide the minnesong reached the height of its glory. In it all the various tendencies of the genre were brought together by a singer who combined acuteness of perception, an almost complete mastery of the spoken word, and a sensitive spirit which could express an endless scale of human emotions. Little is known of the poet's life. He was an Austrian knight who wandered from court to court, earning his livelihood with songs, until in 1220 the Hohenstaufen emperor, Frederick II, granted him a small feudal estate. Walther may have taken part in the crusade of 1227.

Walther's chief contribution to the lyric poetry of his day was the raising of didactic and political songs to the level of literature. Through such verses he became the social critic of his time and an influential propagandist for a strong empire. Because of his attacks on the papacy, he has been called a forerunner of Martin Luther, a designation which fits only in part, for Walther's opposition to the papacy was based only on political grounds.

In Walther's love songs and nature songs the natural freshness and naïveté of the Austrian folksongs appear in metrical forms which reveal all of the ingenuity of the Provençal troubadors. Here his wayward mood vacillates between halfconcealed merriment and mild melancholy. The prevailing temper of the social and political songs is one of dark brooding which often breaks forth in violence and venom. 


\section{(Ihr sult sprechen: 'willekomen')}

In this first patriotic song of German literature Walther sings of the superior grace and excellence of German society. The line "eastward here as far as Hungary" indicates that the verses were composed on the occasion of Walther's return after a long absence to the Viennese court, the place where he had first learned the minnesinger's art.

Welcome and with all good cheer him who brings you stories; I am he.

All the other tales told here were an empty wind. Now come hear me.

First give me my reward, if it satisfies, things I'll tell, perhaps, to open wide your eyes.

See what gifts you can afford!

German ladies shall embrace news of such a nature that they may better charm us with their grace.

That I'll do for no excessive pay. What shall be the fee? I can't reach so high; I'll be modest if the ladies be not shy, and will greet me tenderly.

I have travelled far and wide, have traversed the best of lands indeed; may misfortune be my guide, should I make my erring heart concede that it was impressed by their foreign ways. Well, what would I gain by false and empty praise? German manners are the best!

From the Elbe to the Rhine, eastward here as far as Hungary, there the fairest beauties shine that this wanderer ever hopes to see. He who understands lovely forms as well as I, would swear, by God, our peasant girls excel fine ladies in all other lands. 
German men are all refined, angels can't surpass the women here; who thinks otherwise is blind, so, at least to me, it would appear.

He who seeks in vain culture, love, and light, should come into a land where all of these unite. May I evermore remain!

\title{
WHEN FROM THE GRASS THE MEADOW FLOWERS SPRING
}

(Sô die bluomen ûz dem grase dringent)

\begin{abstract}
Walther probably first sang this song at the elaborate spring festival which the medieval Germans had inherited from their pagan ancestors. The personification of May springs from the traditional rites of May-day and was quite natural for a poet whose forefathers had worshipped the various phenomena of nature.
\end{abstract}

When from the grass the meadow flowers spring and turn their laughing faces toward the sun upon a May-day in the morning dew, and all the birds of field and forest sing their sweetest songs - for who would be outdone, what shall I then compare such rapture to? To half the joys of Paradise.

And yet, if you should ask what can entice me more than this, I should avow what pleased my sight most in the past, and still would, if I saw it now.

For when a lovely and a noble lady, attired in finest clothes and with her hair done up in stately manner, walks with friends of courtly bearing in a garden shady, and looks about at times with such an air as might become the sun as it ascends among the stars, then May can bring us all its wealth and beauty, yet what thing shall with this lovely form compare? We leave May's flowers where they stand and gaze upon the lady fair.

If you would know the truth, then take my arm and let us join the festival of May that now is here with all its joyful treasure. 
Look well! Then look upon the ladies' charm

and tell me who will bear the prize away,

and say which wonder gives you greater pleasure.

I know, if I were forced to choose

the one to keep, the other one to lose,

I'd make my choice with no ado.

Sir May, you would be March before

I'd sacrifice my love for you.

\section{UNDER THE LINDEN}

\section{(Under der linden)}

Medieval German society was very class-conscious and the minnesingers in their love songs made a definite distinction between the courtly love of knights and ladies, with all its traditional etiquette, and the simple, natural love of man and woman. Although Walther usually sang of courtly love, he once declared that "woman" was a more complimentary term than "lady," that femininity was preferable to lofty pride. The naively charming peasant girl who here described a meeting with her lover well supports his claim.

Under the linden

on the meadow

were bedded a lover and his lass;

there you may find

in the shadow

broken flowers and fragrant grass.

By the forest in the dale

tandaradei!

Sweetly sang the nightingale.

I came to the river

and did not tarry:

my lover, you see, had gone before.

There he met me,

Holy Mary,

I'll be blessed for evermore.

A thousand times he kissed me there!

Tandaradei!

See my lips, how red they are.

My lover had laid

with care meanwhile

a lovely bed of flowers for me.

The village maid

will slyly smile, 
who walks there past the linden tree, and sees the spot where on that day, tandaradei!

my head among the roses lay.

Were it known that we

had lain together

(may God forbid), I'd surely die.

May no one ever,

ever know; just he and I

and the little bird that sang this lay:

tandaradei!

It will not give us away.

\section{SAW THE WORLD}

(Ich hôrte ein wazzer diezen)

When the German Emperor Henry VI died in 1197, the political situation in the empire became critical. Henry's son, Frederick II, was elected emperor, but Pope Innocent III refused to recognize him, and other candidates for the throne appeared. Walther supported Philip of Swabia, who was crowned in 1198. The "wretched kings" mentioned at the end of the poem were the kings of England, France, and Denmark, whom Walther accuses of attempting to gain control of the empire.

I heard a river flow, saw bright fish come and go.

I saw the world: all things concealed in reed and grass, in wood and field that creep or walk or fly between the earth and sky. I saw all this and can relate that all things live in fearful hate, that beast and reptile corps wage unrelenting wars, and birds with their own kind unite to carry on a ceaseless fight.

But this I also saw the beasts have still their law. They have their kings and rights and choose their lords and knights. But oh you German lands where no one voice commands, how can the flies their monarch know 
and German honor fall so low!

Unite as oft of old!

The foreign crowns grow bold, and wretched kings reveal their greed.

Lord Philip, wear the diadem

and bid us follow where you lead!

POWER OF LOVE

(Wer gab dir, minne, den gewalt)

Chivalric verse presents love, not merely as a highly idealized emotion, but also as a powerful, capricious, often destructive force, against which the individual struggles in vain. The classic example of such a presentation is found in Gottfried von Strassburg's Tristan and Isolde. Walther's knight is happy that love's chains bind him to one who meets with his complete approval.

Who made you, love, so fierce and bold; who gave you power so immense that you should conquer young and old, and wisdom offers no defense? Well, I'll thank God because, at last, your chains (which I have known so well) now bind me fast to one whom I adore and praise.

I'll never more be free, so grant me, queen, this favor, that I may serve you all my days.

The robust realism of the songs of the Bavarian knight, Neidhart von Reuenthal, present a sharp contrast to the dreamy romanticism of the poetry of his predecessors. Neidhart was the creator of the courtly village song, a type of verse which employed the sophisticated and aristocratic form of the minnesong to treat peasant life and scenes. There is no chivalry here and no attempt to idealize. In lilting dance melodies Neidhart sings of rustic people and events with the superior, often mocking tones of the nobleman and spices his colorful reality with burlesque humor. The songs of Neidhart and his many imitators were well received in court society. This popularity, however, clearly revealed the deterioration of chivalric ideals and hastened the decline of the classical minnesong. Neidhart's verse offers little variety of content. He wrote summer songs and winter songs, the former usually gay, the latter often sombre and even bitter. Many of his melodies have been preserved.

Neidhart spent much of his life at the court of Vienna and took part in a crusade, probably that of 1217-1219, which was led by Leopold VII, of Austria. 
(Heid anger walt in fröuden stât)

Many of the minnesongs were composed to serve as accompaniment to group dancing. This song, with its regular, but varied rhythm, is particularly well adapted to such a purpose. The "vale of tears" referred to in the last stanza is a play upon the name Reuenthal (valley of sorrow).

Field, meadow, forest, as you see, have festively adorned themselves in all the finery that May has placed at their command.

Let us sing, glad with spring:

summer has come into the land.

Come out of your rooms, you pretty maids, and onto the streets; no bitter wind will chill your promenades, and ice and snow have gone away.

Come together

to the heather;

birds are singing, once more gay.

They all are now repaid for pain.

But heed what I have said and come and look upon the plain; and see how summertime can bless, as a friend, it will send every tree a leafy dress.

But those of you who can aspire to something better, now put on your holiday attire and show us what your silver buys. We shall see, gay and free, many flowers before our eyes.

Though I possess a vale of tears, this lovely summer sets me free from all my pain and fears. And now that winter's rage is spent, I shall teach youth to reach for joy, such is my firm intent. 


\section{(Der walt stuont aller grîse)}

Judging from the content of many of his songs, it is assumed that Neidhart was for some time in love with the daughter of a well-to-do peasant. She apparently did not return his affection. It is perhaps she of whom he sings in the last stanza.

The woods were bare and gray,

in ice and snow they lay, but warmer skies have clothed each bough.

See them now, maidens fair, and dance among the flowers there.

From many tiny throats

I heard the silver notes

of little birds in sweetest song.

Flowers throng

in grass and briar, the meadow dons her spring attire.

I love the charms of May;

I saw my darling play

and dance beneath the linden's crown.

Its leaves bent down,

every one,

to shade her from the radiant sun.

\section{DANCE IN A VILLAGE TAVERN}

(Sinc an, guldin huon! ich gibe dir weize)

Neidhart begins this song not with his usual salute to the season but with the plaint which in other winter songs appears at the end. It is, of course, possible that this arrangement may have originated with the medieval collectors of his verse. The references to dances in the poem are interesting. The ridewanze was apparently danced in groups of three, each composed perhaps of a man and two women or a woman and two men. It was a lively dance as compared to the more stately "courtly dance" which the villagers also performed.

"Sing, my golden cock, I'll give thee grain!"

(at her voice

I rejoice)

spoke the pretty maid for whom I sigh.

Thus a dunce's hopes are raised in vain 
seasons through.

Were it true,

no one's spirit then would be as high,

no one else's heart would beat so light.

Will her careless gaiety

ever free

me from all the sorrows of my plight?

Listen! Hear the dancing at the inn!

Every man

go who can,

there the women wait, a merry throng.

Soon we'll see the ridewanz begin.

Tarradiddle

goes the fiddle,

lusty peasant youths break forth in song.

Each in turn sings out his verse with pride,

shakes the room with lungs of brass.

Noblegrass

dances with a maid on either side.

Move out all the chairs and clear the floor;

take the tables

to the stables

and we'll dance till feet and ankles hurt.

Open up the windows and the door;

let the breeze

cool their knees,

blowing through each village wench's skirt.

When the leaders stop to rest a little,

then we'll all, great and small,

short and tall,

step a courtly dance once to the fiddle.

Gozbreht, Willebolt, Gumpreht and Eppe,

Willebrand

(hired hand),

Werenbolt, and also youngster Tutze,

Megenbolt (the farmer's son), and Reppe,

Irenwart,

Sigehart,

Giselher and Frideger and Utze -

he's the stupid oaf from Holingare.

He goes courting every day,

so they say,

but the girls don't like him anywhere. 
Never has a bumpkin looked so grand, nor so flighty;

God Almighty,

how he struts in line before the rest!

More than two hands wide the leather band of his sword,

like a lord

in his new and gaily colored vest,

scraps of every shape and hue are there, fancy shirt, embroidered pants,

see him prance

in a garb no other fool would wear.

His attire is rustic as can be,

it's absurd.

So I've heard,

he's been wooing Engel's daughter, Pearl.

All such hopes are futile, I foresee.

She's a prize

of shape and size

to win the admiration of an earl.

Good advice I'll give him: let him try

someone else; for all his pain

what he'll gain

he can take to Mayence in his eye.

Though his clothes are colorful and gay

and he's dressed

in his best,

he should know, she simply can't abide him.

He has hung around her every day;

I became

red with shame

when I saw her sitting down beside him.

If I win this maid who looks so pretty,

I shall give to her my all,

Reuenthal,

for her own: this is my fabled city. 


\section{THE BAROQUE POETS}

The history of the decline of the minnesong from the matchless verse of Walther von der Vogelweide to the superficial and often meaningless metrical exercises of those simple artisans of the sixteenth century, the mastersingers, is the story of the futile attempt to maintain a specific content and form when the culture which had produced them had vanished. The intervening centuries saw the political power of the nobles being challenged by that of the growing free cities, agrarian feudalism being threatened by the development of a rival, mercantile economy, and the harmonious union of religious and secular life destroyed. Whereas the culture which had produced the minnesong was based on harmony, moderation, and unity, the culture at the beginning of the seventeenth century was one distinguished by dissonance, extravagant ornamentation, and polarity characteristics which earned for it the name Baroque.

The religious-secular polarity of the seventeenth century exerted a strong influence on literature. It is seen particularly in the inimical extremes of mysticism and Renaissance. The mysticism which affected the Baroque poets had its beginning in the thirteenth century, received a great impetus in the following century from the writings of Eckhart, Tauler, and Seuse, and became widespread in the seventeenth century through the works of Jakob Böhme. Mysticism despaired of reconciling spiritual and worldly goals and, consequently, renounced the latter. Temporal existence was no more than a preparation for eternity, and the physical desires and worldly ambitions which retarded this preparation had to be cast off. Even the individual personality was something which through its mere existence opposed spiritual perfection and was, therefore, to be given up through union with the divine personality, a union productive of perfect bliss. The three steps toward true happiness, then, were purification from the world, illumination (an ecstatic insight into the mystery of God), and union with God. Such a union, though begun on earth, could become complete only in death, and for this the true mystic yearned.

The increasing preoccupation with the affairs of this world, the counterdevelopment to mysticism, can be traced from the establishment of the first German university in the fourteenth century, through sixteenth-century humanism, to the seventeenth-century Renaissance. Humanism with its emphasis on classic Greek and Roman culture had demonstrated that man could apparently get along very well without the Christian God; and the Italian Renaissance, which belatedly made its way into Germany, stressed 
secular culture and human potentialities. Mysticism and the Renaissance were warring forces between which the Baroque poet was torn.

Baroque culture was formed, at least in part, by the schismatic effect of the Reformation, an upheaval which divided Protestant and Catholic, north and south, and created further religious, philosophical, and political polarities. The most immediate effect of the Reformation on poetry is seen in the emergence of a new genre, the congregational hymn. With regard to structure, the hymn is based primarily on the folksong, which in the preceding century had reached the height of its development. The typical folksong had a simple melody and simple metrical construction. It was generally iambic with a short line and employed rhymes which were seldom pure. The structure was very loose and allowed great freedom in syntax and verbal arrangement. The emphasis was on subject matter rather than on aesthetic value. These characteristics appear in the congregational hymns, which often were mere reworkings of popular dancing songs, love songs, and even drinking songs.

The more formal and pretentious verse of the seventeenth century, like that of the twelfth century, was strongly influenced by the poets of France. The French influence on German Baroque was largely unfavorable, since it brought into vogue a verse form, the hexameter line, which is generally unsuited to Germanic languages. The favorite genre for formal verse was the Italian sonnet, which for the first time began to be widely employed by German poets and served as a medium for both secular and religious expression.

Paul Gerhardt was a Lutheran pastor who was born in the state of Saxony, but spent much of his adult life in Berlin. He was the greatest of the host of hymn writers whom the Reformation and the Counter Reformation produced, and many of his songs are as popular today as they were three hundred years ago. Gerhardt belonged to the second generation of Protestant hymn writers, a generation which had lost something of the objective, congregational approach to religion and much of the militant vigor which Luther displayed in such a hymn as "A Mighty Fortress Is Our God." Although not completely subjective, Gerhardt's songs deal with a personalized, individual relationship to God, a relationship, however, in which man does not renounce his identity. His attitude toward the world around him is moderately Baroque. Although he regarded it as transitory and significant only in its relationship to eternity, still a love for nature and beauty as things meaningful in themselves permeates much of his verse. Certainly the world about him was more than a "vale of tears."

Gerhardt possessed a firm conviction of the objective truth of the Lutheran doctrine of salvation and an appreciation of human values and achievements. Influenced by both mysticism and the Renaissance, he kept to the middle road 
between them and was dominated by neither. The inspiration for his hymns was drawn from many sources, especially from folksongs, Latin hymns, and the Psalms.

\section{NOW SLEEP BENEATH NIGHT'S SHADOWS}

\section{(Nun ruhen alle Wälder)}

Gerhardt's strong, sincere faith, which is the source of his optimism and his protection against Baroque duality, is clearly seen in this evening song. It was inspired by lines 522-528, Book IV, of Vergil's Aeneid, but, in its antiphonal form, is also strongly reminiscent of the Psalms. The first three lines in each stanza describe the approach of night, while the second three lines constitute a religious commentary or response. Several stanzas of this hymn and the subsequent hymns have been omitted.

Now sleep beneath night's shadows

men, cattle, woods, and meadows;

the wide world is at rest.

But wake, my heart, renewing

your strength, be up and doing

what pleases your Creator best.

The glowing sun has vanished;

its rays the night has banished

and forced it to depart.

But still another splendor, my Jesus, mild and tender, shines ever brighter in my heart.

The weary day is over and golden stars now cover the blue of heaven's hall. So shall I gleam tomorrow, when from this vale of sorrow I go at my dear Father's call.

Tired feet and hands returning to rest and home with yearning, rejoice that toil is past.

My spirit, be contented, though now by sin tormented, you'll lay its burden down at last. 
(Geh aus, mein Herz, und suche Freud)

Written in the manner and with the spirit of the traditional May song, the delightful affirmation of life in this hymn contrasts strongly with the asceticism and abnegation prevalent in Catholic and to a lesser extent also in Protestant religious songs of the period.

Go forth, my soul, and seek delight where all of summer's joys unite in God's abundance daily. And see how fair the garden's are, behold how nature, near and far, adorns itself so gaily.

Each tree displays a leafy crown, the earth has decked its dusty brown with velvet, green and tender. The lily with its silver bells is dressed in raiment that excels a king in regal splendor.

The meadow lark soars high above, and from its crevice flies the dove, into the forest winging.

And from her branch the nightingale fills wood and pasture, hill and dale with echoes of her singing.

The river wanders through the sand, and there the sun with trembling hand paints reeds and willows swaying. Beside the bank the meadow lies and rings with merriment and cries of sheep and shepherds playing.

And I, shall I alone be still? My Father's deeds and wondrous will stir every deep emotion. I'll sing when all creation sings, and all the joy that nature brings pour forth in true devotion. 


\section{(O Haupt voll Blut und Wunden)}

This well-known hymn is a free translation from the "Salve Caput Cruentatum" (1153), ascribed to St. Bernard of Clairvaux. The melody to which the hymn is sung was borrowed from an early seventeenth-century love song.

Oh sacred head now bearing a weight of pain and scorn, oh wounded head now wearing a heavy crown of thorn, oh head which once in splendor reigned over land and sea, and now has no defender, with awe I honor thee!

The torment and oppression, the crushing load of care, are fruits of my transgression, a burden I should bear. I stand here, poor and lowly, ashamed before thy face; oh grant me, Lord, most holy, the wonder of thy grace.

And when death comes to take me, be thou a friend and guide, who never will forsake me, but wander at my side.

When heart and soul shall languish and fear rise as a flood, then save from bitter anguish through thy atoning blood.

\section{PAUL FLEMING (1609-1640)}

Paul Fleming was born in a small town in Saxony, the son of a Lutheran pastor. He studied literature and medicine at the University of Leipzig and graduated as both a Doctor of Philosophy and a Doctor of Medicine. After concluding his studies he became a member of a government mission to Russia and then to Persia and did not return home until shortly before his death.

With such a background of education and travel, it is not surprising that Fleming's verse should be much more sophisticated than that of Gerhardt. 
Where the latter's verse derives largely from native sources, that of the former developed primarily from Latin and French poetry. Fleming was a master of poetic form and experimented with a great number of different metrical and stanzaic patterns. Yet for all their complexity, his poems seem natural and unforced. Their customary mood is one of light-hearted sincerity, with neither the gloomy passion nor the superficial frivolity which characterized much of the verse of the period. His love-poetry, though not free from Baroque exaggeration and hollow rhetoric, is the most lyrical of the seventeenth century.

ODE TO MYSELF

\section{(Lass dich nur nichts nicht tauren)}

The charm of many of Fleming's poems lies in the expression of simple, direct sentiments in a complicated stanzaic structure, as in this poem. His use of monometer for emphasis is quite effective here.

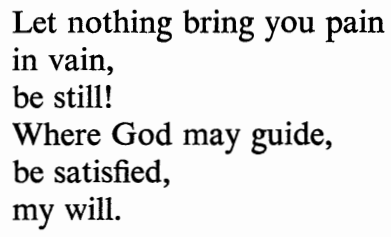

Why seek tomorrow's pay today?

He who

his love has shown will give your own to you.

Be firm in each affair and bear each test. What God ordains for you remains the best.

(Es ist umsonst, das Klagen)

Fleming spent nearly a year in Esthonia and there fell in love with the daughter of a German merchant. The poem may be one of the many which he later sent to her from Persia. 
It is in vain, the sorrow, that you with tears and I with fears for one another borrow; and idle is the bitter pain with which we now our love profane.

Care not though fate assail us. What makes you dear and leads me here will surely never fail us. And this, which now is sore distress, is still our source of happiness.

Be mine, and faithless never; more mine than $\mathrm{I}$, so you may tie me to your heart forever. A love as ours is firm and fast and keeps its promise to the last.

I swear by all I treasure that this is true: it's you, it's you who gives me peace and pleasure. My heart, today a heavy stone, has chosen you, and you alone.

Be as you were hereafter, that we may reap though now you weep rewards of love and laughter; that for this passing time of pain eternal joy shall be our gain.

Depart, you dreary hours! Depart from me and set him free whom yearning grief devours. But oh, make haste, you sunny days when beauty fills my heart with praise. 
(Ich feure gantz und brenne liechter Loh)

This sonnet, which was also sent to his sweetheart in Esthonia, is almost unique for the period in that it is written in pentameters instead of the usual hexameters.

I'm all ablaze and burn with violent glow. These tears are but the guardians of the flame and do not let this constant suffering maim; I know full well that which can heal my woe, that $\mathrm{I}$ in torment need not sorrow so.

But where is she, my one desire and aim? The fires of hell their victim still shall claim; my shield is gone, for aid where shall I go? Is nothing left with which to cool my brow in such a fever as consumes me now? Love's parching thirst burns soul and body up. This water cools the flames that agonize, this balm that rushes forth from both my eyes. I tap the stream and Cupid fills the cup.

\section{ON THE DEATH OF A CHILD}

\section{(Auf den Tod eines Kindes)}

Perhaps no phrase reveals the polarity of the German Baroque better than its favorite expression, "vanitas vanitatum." Some poets uttered the words in the religious fervor of other-worldliness, for others it was a cry of despair, and some spoke them with a sort of sophisticated pride. Although Fleming reflects the mood or moods of "vanitas vanitatum" less frequently and less intensely than many of his contemporaries, it nevertheless colors much of his verse.

Pleasant dreams, my little friend.

Hosts of gallant heroes perish, peoples, times, and all we cherish drive as dust before the wind. How may mortals persevere when the ages disappear?

Pleasant dreams, in sorrow we, to our well-worn paths returning, old in years and young in learning, tend our folly faithfully. Blind of eye and deaf of ear, we remain as children here. 
The poems of Andreas Gryphius are the revenge which a strong and bitter man took on a world which constantly hounded him with great personal sorrows, with the loss of father, mother, sister, brother, children, property, and home, in an unceasing and unrelenting series of misfortunes. His dark melancholy describes the sufferings and conflicts of humanity which struggles between heaven and hell, sin and salvation in an existence which finds meaning only in its conclusion. Gryphius does not, however, find or seek refuge in mysticism, but asserts himself as an individual in this unequal strife. His works are deeply religious, even though his religion offers him not joy, as with Paul Gerhardt, but only salvation.

In spite of early poverty, Gryphius managed to obtain an excellent education, and he read widely in the thirteen languages which he knew, particularly in Latin and Greek. His verse employs an animated and dramatic vocabulary and a complex structure, usually that of the Petrarchian sonnet or the Pindaric ode. Although the poems of Gryphius have not been forgotten by succeeding generations, his fame rests primarily on his dramatic productions.

\section{VANITAS MUNDI}

(Was ist die Welt)

The theme of vanitas mundi dominates the verse of Gryphius and the theme is usually developed as it is here. A series of examples illustrating the emptiness of temporal existence is followed by an expression of confidence in eventual salvation.

What is the world whose splendor long my eager steps directed?

How soon is hurled

from its high place what young and old respected! And what is all that here may charm and please?

A vagrant breeze.

What blooms today, today may fade and cease to give us pleasure.

Who lays away great wealth, departs and leaves behind his treasure. He gathers that which he can never own and dies alone.

The tiny worm becomes ensnared by silk of its own weaving, so we confirm 
our death through all our striving and achieving. For all the knowledge which we seek and save leads to the grave.

The tulips, when they blossom, soon are plucked by careless lasses. And see how men must suffer scorn for beauty which surpasses, and (should kind death not quickly intercede) distress and need.

And as the ship with stormy, restless seas has ever striven, so sorrows whip these troubled waters: soon our lives are driven and tossed about from wave to jagged reef in fruitless grief.

How happy he who sails unharmed into the port appointed, and who can see the one true course of all the Lord's annointed. For he, though waves as mountains surge around, will not go down.

\section{EVENING}

(Der schnelle Tag ist hin; die Nacht schwingt ihre Fahn)

The sonnets of Gryphius excel more in their forcefulness than in their smoothness and unity. It is characteristic of Baroque extravagance that he should use several conflicting metaphors in the short length of a sonnet without developing any of them. In lines 1 and 2 he pictures a general taking charge of a camp, line 5 uses the metaphor of a ship, lines 7 and 8 describe life as a racetrack.

The hurried day is gone; its banner swings the night and posts a starry watch. Tired men, a silent herd, forsake their fields and shops; where once was beast and bird grey solitude now mourns. All time is waste and blight! For ships of aching limbs the port comes into sight. And as this day now fades, an idle, empty word, shall you and I and what one has and sees, unheard, pass on along this racetrack in our hurried flight. Oh highest God! May I not falter in this race! 
Let neither pain nor pride, nor lust nor fear abase! Surround me with thy glory! Aid and comfort me! And when this body slumbers, let my soul awake, and when the evening falls on that last day, oh take me from this wretched world of darkness home to thee!

\section{TO EUGENIE}

(Ich lebe, wo man den mit Recht kann lebend nennen)

Gryphius fell in love with Eugenie while he was a student at Leyden and continued to write sonnets to her for many years after his departure. Such conceits as "eyes... in royal splendor burn" and "spirit which... no thunderbolt can shake" are ilustrative of Baroque bombast. The "roses" are perhaps memories of Eugenie.

I live as one may live who only lives to yearn, whose lonely heart dissolves in sweet and bitter pain, my soul has taken wing and seeks the far domain where those fair eyes I love in royal splendor burn. In blackest night who can his guiding star discern? But see! Her radiant face can gloomy shadows chain and light this spirit which - though worlds may split in twain no thunderbolt can shake nor from its purpose turn. Rage, wind and weather! Since these roses bloom for me, I'll fear no winter's wrath. Let summer's warm sun flee! The evening air is sweeter than the heat of day. Although the tongue is still which could delight me so, and though the pallid cheeks have lost their sunset glow, she speaks in clearest tones who now is far away.

\section{JOHANNES SCHEFFLER (1624-1677)}

Johannes Scheffler was born in Silesia, the homeland of many religious and philosophic poets. He came from a Lutheran family, but at the age of twentynine he joined the Catholic Church and took the name Angelus Silesius. His conversion was due in part to a reaction against the strict, cold orthodoxy of the Lutherans, with its just but distant God, and in part to his study of the works of Jakob Böhme and the fourteenth-century mystics. All of Scheffler's verse is religious in nature. It describes in erotic, sensuously ecstatic language the coalescence of the individual with God. Baroque style appears to an exaggerated degree. Bold symbols and startling parodoxes are extravagantly employed in the effort to render the supersensual in tangible form and to dissolve the world of phenomena into the supernatural. His fervor knows no 
bounds as he pours forth a flow of rapturous tears, of trembling and stammering, of melting self-negation and erotic languishing. Yet for all his excesses, Scheffler's poems reveal a depth of feeling and passion unique in his century. That they struck a universal chord is indicated not only by their popularity in Scheffler's day, but also in the fact that they appear in contemporary hymnals.

\section{JESUS, GOD OF LOVE}

(Jesu, du mächtiger Liebesgott)

Unlike the hymns of Gerhardt, those of Scheffler show little relationship to the form of the folksong. For where the folksong usually has a consistent metrical beat, Scheffler preferred to vary his rhythm by using a variety of feet. It will be noted in this poem that, although the iambic foot predominates, lines one and three of each stanza are made up of dactyls and trochees.

Jesus, thou mightiest God of love, come now to me; let me not perish of grief and of desire for thee.

Oh seize thine arms and send thy dart that it may fly and pierce my heart; oh wound me now.

Come thou my sun, thou my inmost light, my domicile; come thou to warm me, the falling night is dark and chill. And kindle flames within my breast this frozen heart to melt and test with raging fire.

Sweetest of passions that fill the soul, glow through me now;

pour me anew from the casting bowl, great Founder, thou.

And stir the fire till the caldron gleams and my heart in molten, flowing streams unites with thee.

Then shall I tell how my soul was freed from death's domain, and that thou came as a friend in need to ease my pain.

I then shall praise thy love and grace, my bridegroom, who will kiss, embrace, and not forsake. 


\section{Selections From THE CHERUBIC WANDERER}

The Cherubic Wanderer is a collection of aphorisms in alexandrine couplets, the aim of which is to reveal the way to a complete, mystical union with God.

I am as great as God, he is as small as I, he cannot rise o'er me, nor I beneath him lie.

When I forsake all time, I am eternity, and close myself in God and draw him into me.

I am as rich as God, no speck of dust may be, which (man, believe me this) he does not share with me.

How blessed is the man who neither wants nor knows, for God (now hear me well) no praise, no prize bestows.

Hear wonders! Jesus is the lamb and shepherd too, when God within my soul as man is born anew.

The man whose sun doth shine ought not to look about and wonder if the moon and other stars are out.

Who nothing wants nor has, nor knows, nor loves, nor will, he has, he knows, desires, and loves exceeding still.

And what then may I be? I am the church, the pew, I am the priest of God and am the offering too.

Oh man, you will be changed to that for which you lust, to God, if you love God, to dust, if you love dust.

Christian Hofmannswaldau, like Gryphius, studied at the University of Leyden and travelled widely before he settled down as Imperial Councilor in his native city of Breslau. His official duties were largely nominal, and his life was one of wealth and leisure. As a nobleman, he represented a higher stratum of society than did the other Baroque poets included here and also represented a quite different attitude toward literature. For Hofmannswaldau and the group of writers to which he belonged, literature was neither a medium for teaching religious and moral truths, nor was it an instrument for the expression of pent-up emotions. It was nothing more than the pastime of educated and cultured gentlemen, the plaything of their wit and pleasantries. For them art had 
little to do with life, although they reflected more than they knew the complicated mores and the superficialities of their existence in their verse. This verse emphasized virtuosity of technique rather than content. Its goal was to preserve the purity of the language and the beauty of form.

Hofmannswaldau writes about all aspects of the society he knew, but through all of his poetry, whether festive, religious, or elegiac, runs a pronounced erotic vein. Not the passionate, mystic eroticism of Scheffler, but a sentimentalized and witty eroticism. His polished verses flow with Baroque sensuality, irony, and grace, and are not as bombastic as those of most of his contemporaries. Frivolity characterizes all of Hofmannswaldau's work, and this frivolity is as characteristic of the complex Baroque culture as the religiosity of Gerhardt, the despair of Gryphius, or the mystic ecstasy of Scheffler.

SENSUAL JOY

(Die Wollust bleibet doch der Zucker dieser Zeit)

Such imagery as the rose baring her beauty, jasmine bidding us admire, and the man stroking the swan's white breast illustrate the erotic nature of Hofmannswaldau's verse. However, even in this song to sensual gratification, Hofmannswaldau is not to be taken too seriously, since his own personal life appears to have been conducted quite properly.

The joy of sense is still the sugar of this time; what sweetens more than that this life through which we pass? It causes liquid gold to flow from every glass, and opens up a wealth of happiness sublime; it turns both snow and ice into exotic flowers, and keeps the whole year long the spring's enchanting hours.

For nature looks at us as simple children all, and gives us bounteously the riches of her breast. She leads us into halls where sugared spices rest, where every wish is stilled and all delights enthrall; she pours out sensual joy the baby's heart to charm, and love and wine to keep the older spirit warm.

But law will always play the tyrant, hard and cold. It shows to every age a hostile, sour face, and every human joy and freedom will erase, gives vinegar for wine and sombre lead for gold; it dares to bind our eyes from pleasures all around, and boldly takes from us the little joy we've found. 
The silken rose does not in vain her beauty bare, and not for naught does jasmin bid us all admire; they only wish to serve, and favor our desire. He is his own worst foe who loads himself with care; who'd rather grasp at thorns than stroke a swan's white breast is clearly short on wit, of sense quite dispossessed.

What good is youth and strength and figure prepossessing, if one does not enjoy earth's fruits till he is sated and lets his sugar stream rush by unnavigated? For earthly pleasure still is mankind's greatest blessing; who here sets sail will live as fortune's favored son, she'll shower him with love until his journey's done.

Who Epicurus scorns and turns his back on mirth has little of good taste and less of common sense; he is not nature's child who offers such offense, a thankless brute is he, the horror of the earth. The folly of most teachers causes pain and smart; what Epicurus teaches, gratifies the heart.

\section{THE IMPERISHABLE}

(Es wird der bleiche Tod mit seiner kalten Hand)

This sonnet offers an excellent example of the luxuriance and sharp contrasts which make Baroque literature and art so interesting. In his dual picture of the lovely woman of today and the corpse of tomorrow Hofmannswaldau presents the polarities of life and death, beauty and ugliness, warmth and cold, hope and despair which played such an important role in the culture of his age.

Pallid death in time will pass his icy hand about your form and blight the fulness of your breasts; the crimson coral of your lips will fade, the crests and warm snow of your shoulders change to dry, cold sand. The lightning of your eyes, the strength of your small hand, which I hold fast in mine, they too will fail time's tests; each flowing hair that now the gleam of gold suggests, the days and years will fade and make a lifeless strand. Your dainty foot, your limbs, and all your lovely being will turn to dust and nothingness - unseen, unseeing; who then brings offerings to the altar of your charm? All this, and more than this, will sometime cease to be; your heart and it alone will last eternally, for nature made it from a diamond, clear and warm. 


\section{WHERE ARE THE HOURS}

\section{(Wo sind die Stunden)}

Hofmannswaldau's preoccupation with form produced a variety of metrical systems and stanzaic structures. The stanzas below consist of dimeter, trimeter, pentameter, and tetrameter lines in an arrangement which resembles some of the minnesongs.

Where are the hours

of that sweet time, when first I felt the powers

of your charm sublime

bind me with flowers?

They've passed away and I can only sigh that every happiness must die.

Jest is an art that pleases me, and deep within my heart its monument shall be, its pain and smart.

You let me know in language more than clear, your favor will not anchor here.

The memory of sweet delight with fear encircles me; damned food and appetite destroy us quite.

What has been tasted once and not again is savorless and full of pain.

Yesterday's kiss, ambrosian juice, is now no longer bliss and of no further use; the spring we miss which once could still our thirst. The heart is gay with pleasures only of today.

My spirit thrilled, her kind concern my every wish fulfilled, but now the pages turn and joy is stilled.

I weep today that love and sunny hours are never free from fears and showers. 
(Was ist die Welt, und ihr berümtes gläntzen)

The pentameter line and the unusual simplicity of structure contribute much toward making this one of Hofmannswaldau's best poems. Metaphors bordering on the repulsive, such as hospitals infested with disease and rotting tombs, frequently appear in his verse and are quite characteristic of the literature and painting of his day.

What is the world, its celebrated splendor?

What is the world, its glittering delight?

An empty show, an insolent pretender, a lightning flash in overclouded night.

A blooming field where prickly thistles wave, a spacious hospital where sickness hides, a house of bondage where each man's a slave, a rotting tomb with alabaster sides, that is the ground we mortals build upon, the idol which the human flesh holds dear. Come spirit, come and learn to look beyond the narrow confines of your dwelling here; strip off its gaudy luxury and cast away its barren joys, each single trace, and you will sail into the port at last where beauty and eternity embrace. 


\section{POETS OF THE ENLIGHTENMENT}

The Enlightenment was the German version of the Age of Reason which prevailed in Western Europe and the British Isles throughout most of the eighteenth century. In contrast to German Baroque, which had been distinguished by polarity and variety, the Enlightenment was characterized by a general harmony and uniformity in thought and culture. The Baroque man had sought truth and knowledge in the declarations of God as revealed in the Scriptures and as interpreted by the theologians. This authoritarian approach to knowledge had been discarded already in the seventeenth century by the French philosopher Descartes, who proclaimed that the thinking mind was the one certain fact of existence and, therefore, the only starting point in the search for truth. Soon afterwards revelation was further undermined by the Englishman, John Locke, who set the beginning of knowledge in the sensual perception of the natural world. Both philosophers announced the supremacy of human reason. After the middle of the seventeenth century, Cartesianism began to be taught at the German universities, and the student was urged to accept the autonomy of his own mind and to judge the world on the basis of his reason. The logical mind should decide between good and evil, right and wrong, fact and fiction.

Although the Enlightenment owed its beginning to foreign sources, its particular form was determined primarily by the German philosopher, Leibnitz. Leibnitz saw God as the embodiment of mathematical reason, a reason that penetrates and fills animate and inanimate nature and reigns as the preestablished harmony or order of the universe. This order is not a mystery, but satisfies the demands of human reason, in so far as the pertinent facts are known. The world about us, guided by infinite reason, is the best of all possible worlds, where even apparent evil is seen to be only a means toward eventual good. Where the Baroque man, loaded down with hereditary sin, had regarded existence as punishment and had looked forward to heaven as his hope for release from pain, the man of the Enlightenment saw the world about him as a source of enjoyment, where sensual desires were not per se to be suppressed, but only to be guided by reason. The old polarities were resolved in a logical system which made the well-being of man the goal of creation. The Enlightenment presented an optimistic Weltanschauung, an unlimited confidence in the power of human reason to solve all human problems.

It should not be assumed, however, that the literature of the eighteenth century was all optimism and rationalism. For out of the increased significance 
which the Enlightenment placed on individual man came also the increased significance which the individual placed on his own feelings and emotions, and we see in the literature of the time the pronounced subjectivity which has caused the eighteenth century to be designated not only the Age of Enlightenment, but also the Age of Sentiment.

The literature of the period has a natural tendency toward didacticism. For the new era had brought not only freedom from authoritarian revelation, but also an increased responsibility for the advancement of that which is useful and good. The expression of man's enjoyment of sensual pleasures is seen in the prevalence of anacreontic verse. The feeling of harmony between man and nature produced the great mass of pastoral poetry for which the eighteenth century is particularly known. The new subjectivity is apparent in the emphasis on sentimentality and emotionalism in literature.

Literary style varies from straightforward, almost realistic expression to a highly complex Rococo, with its playful merriment, pretentious delicacy, elegant gallantry, yielding tenderness, and refined and frivolous eroticism.

\section{CHRISTIAN GÜNTHER (1695-1723)}

Although the poetry of Christian Günther shows the influence of the Enlightenment, it remained essentially Baroque. It is characterized by tension and strongly contrasting moods. And where a more typical poet of the eighteenth century maintains, even in sorrow, a certain confidence in himself and in a benevolent universe, Günther often bewails his helplessness and rages at an inexorable fate with true Baroque abandon. This transition poet was born in Silesia into the family of a physician and natural scientist. The boy early displayed considerable poetic ability and determined to make a career of literature. He attended the universities of Leipzig and Breslau, but his student years were largely misspent in living riotously, accumulating debts, and indulging in a long series of more or less serious love affairs. Literature offered no means of support, and Günther reluctantly turned to the study of medicine. When he began his practice, however, he so neglected it that he was soon reduced to poverty. He died at the age of twenty-eight, broken in health and spirit by a life of care, privation, and dissipation.

Seldom has a poet so lived his verse and versified his life as did Günther, whose poems make up a tragedy in monologues. From the most tender love song to the stormiest, most despairing lament his verse bears the unmistakable mark of having been experienced. He is completely subjective and shows an almost naturalistic verity in the revelations of his inmost being. Günther is a true son of the Enlightenment in his desire for reality and vividness. This passion causes him to materialize all characteristics and occurrences, all virtues and vices. His talent draws the reader into his mood and even into the actions which he depicts. Günther composed religious verse, convivial verse, satires, and love songs. His verse and stanzaic structure shows ingenuity without 
seeming artificial. His language is distinguished by originality, but he often wrote hastily, and many of his most lyrical poems are marred by occasional inapt expressions.

\section{A MADRIGAL TO HIS MAgDalis}

(Mein Kind, ich bin der Huld nicht wert)

When he was nineteen Günther met and fell in love with Magdalena Eleonore Jachmann, a beautiful woman six years his senior, who became the inspiration for a large number of his poems. The madrigal verse form had come into Germany from Italy at the end of the sixteenth century.

My child, I am not worth the grace,

the honor, you bestow on me with each embrace;

so do not scold, but be -

if I am somewhat bold -

not scandalized and cold.

Know this with certainty:

if from out your favor's store

you should let my lips once more

kiss your pretty mouth and ear,

then indeed, I fear,

such sweet rapture I would feel,

such ecstasy would steal

all my desire for Paradise

and make me think these joys well worth the sacrifice.

FAREWELL ARIA

(Schweig du doch nur, du Hälfte meiner Brust)

There were many partings during the five-year engagement to Magdalena Eleonore, and the many farewell songs gave expression to both sorrow and foreboding. For Günther was a jealous lover, and the suspicion he voices here was real. Actually, however, Eleonore had much more cause to be jealous than he.

Be still, my love, no tears, you half my breast, for what you weep from out my heart is drawn. I reel, I tremble, all desires repressed except the faithful pain, caught from the dawn the cruel star that yet divides our lives and burns my eyes. 
Urged on by strokes of ceaseless fate and time your farewell kiss locks up my happiness.

As once the sunlight from your face would shine, so now the lightning marks my deep distress; and doubts awake, your faithfulness pursue: you are untrue.

Do pardon me for my suspicious mind; the fervent lover always dreads these fears, its many changes prove the heart unkind. Who knows when to my soul the news appears that she, who in my presence kisses me, forgets when free.

Just think how beautiful our lives once were, how our desires we secretly expressed; no jealous thoughts opposing the allure with which you clasped me to your neck and breast; no watchman nor his warnings to obey, as calm we lay.

Remember often all my tenderness, and add to it sweet memories of your own. You will grow sad, the farewell's sharp impress; with dawn, my one offense - you're left alone; when my first steps from here our lives untie, to you I die.

Enough! I must, the torturous bell declares. From out my mouth receive my aching heart and lift it up; the mellow fruit it bears are peace and comfort, evil hours depart. And when alone with grief and pain you dwell, read my farewell.

\section{A STUDENT SONG}

(Brüder! Lasst uns lustig seyn)

This drinking song was composed while the poet was a student at the University of Leipzig. It is still a favorite student song.

Brothers, let us all be gay while the spring is here and the sunshine of our May 
floods this bower with cheer.

For grave and casket will not wait;

who gathers roses all too late

will wear no garland here.

Steeds that bear our lives in flight

shake the road like thunder;

spurred by fortune's jealous might, they split each bar asunder.

Make every fleeting joy your own perhaps they're cutting on the stone that you will moulder under.

Where are they? Where can they be, who from us are parted, and but yesterday, as we, were young and happy-hearted? Their bodies lie beneath the sand, their souls into another land most hurriedly have darted.

You who seek your fathers' homes, search the cemetery; there perhaps some rotting bones may answer to your query. The hand of Providence may bring us, still before the church-bells ring, where we shall not be merry.

Meanwhile we must carry on here, with fate's permission "Drink until the beer is gone," was Father's admonition.

So I shall get a healthy glow, and all you others, be not slow to keep the old tradition.

This first glass I drink to all may your sweethearts love you, may posterity install marble statues of you.

So make your toasts! When all's been said, then raise your glasses overhead and pledge the wine above you. 
(Stürmt, reisst und rast, ihr Unglückswinde)

The despair which shows through the bold language of the poem came from Günther's realization that, after a four-year engagement, he was still financially unable to marry. And his protestations of loyalty resulted from the fear that Leonore might not wait much longer for him. The Titanism of mood and language is anticipatory of Storm and Stress.

Storm, rage, and howl, you winds of fate;

display the evil you can do!

Tear down the branches in your hate and break the tree of hope in two!

Though thunder crash and lightning slash, the roots remain.

When sleet and snow have ceased to blow, the leaves and branches will spring forth again.

A precious stone is not as hard, an oak is not as strong as I.

Though earth and heaven may be barred to me, I'll laugh against the sky.

Though foes assail and friendships pale, still I shall stand against the throng with courage strong, and see what wonders patience can command.

Love pours a wine and weaves a spell to steel my courage in the fight; she promises to pay me well and sends me forward as her knight.

Here shall I strike with sword and pike for victory. Upon my shield a bright green field, two golden anchors, and a palm shall be.

For I shall be a constant knight and always love you faithfully until the time the poets write 
that ours is immortality.

And faithfulness

will soothe distress

and every ill.

The fever's heat

will soon retreat,

if you but patiently subdue the chill.

But do not doubt my loyalty, that as a flaming torch I wave, which even when death comes to me, shall light the darkness of the grave.

No power of fate

can separate

me long from you.

I am your own

and yours alone,

so do not doubt, but know that I am true.

\section{FRIEDRICH KLOPSTOCK (1724-1803)}

The great literary Renaissance of the late eighteenth century and early nineteenth century, in which Goethe, Schiller, and the Romanticists took part, had its beginning in the powerful emotionalism of Friedrich Klopstock. Klopstock's life was singularly peaceful and uncomplicated, and had little direct effect upon his works. He was born in the Prussian town of Quedlinburg, studied theology at Jena and Leipzig, and spent his adult life in Copenhagen and Hamburg. With the appearance of the first three cantos of his monumental work on the passion of Christ, The Messiah, Klopstock's fame spread rapidly, and, while still in his twenties, he was universally acclaimed as the outstanding poet of Germany. In addition to this work, the poet composed numerous odes. These are enthusiastic outpourings of deep emotion which treat their themes in an exalted manner. In them the poet attempts to create a richer, more poetic language with coined words and expressions, and with a sentence structure which often differs widely from that of normal speech. A more fortunate innovation was the use of variable rhythms, which opened up new possibilities for poetic expression.

Klopstock is essentially a religious poet, and most of his themes have a religious significance. He writes often of nature, but it is not nature which he presents. It is rather the divine spirit which nature reflects. For the poet cannot remain long with concrete phenomena. In his hands phenomena soon evaporate into emotions and ideas.

Since Klopstock's metrical patterns are unusual and often not immediately apparent, they will be schematically indicated above some of the poems included. 
(Im Frühlingsschatten fand ich sie)

This is one of the odes to Meta Moller, whom Klopstock later married. Under the name Cidli she appears in many of his poems.

I found her in the shade of spring and bound her then with wreaths of roses; she felt it not and slumbered on.

I looked at her, and in this glance my life was joined to hers forever; I felt it, though I knew it not.

I stammered several broken words and made the leaves and petals rustle; then from her slumber she awoke.

She looked at me, and in this glance her life was joined to mine forever, and round us was Elysium.

\section{THE YOUTH}

(Schweigend sahe der Mai die bekränzte)

Klopstock here presents an allegory of careless, lighthearted youth, which is not aware of the trials and sorrows which confront it.

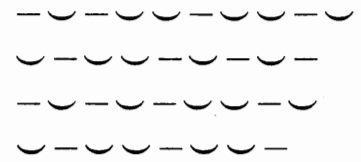

Silent May saw his myrtle-crowned ringlets reflected in quiet, silver brooks.

Bright his wreath and red as the sunrise, he watched it and placidly smiled.

Raging hurricanes pounded the mountains, the ashes and oaks and fir-trees broke; maples plunged with masses of boulders from quivering ridges and peaks. 
Mildly slumbered the May by the water, unmoved by the howling wind and storm; dozed and slept, caressed by the blossoms, and woke with the evening star.

Now you feel still no trace of misfortune and life, as the Graces, laughs at you. Up, and arm yourself with all wisdom, for, know youth, the flowers will fade.

THE EARLY GRAVES

\section{(Willkommen, O silberner Mond)}

Klopstock was only forty at the time the poem was composed, but already his wife and many of his friends had died. Theirs are the "early graves." The transition between the moon and the graves is provided by the second stanza, which describes the moon's rays mounting the hill till they illuminate the gravestones.

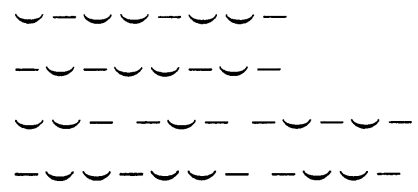

I welcome you, silvery moon, lovely, silent compeer of night.

Must you go? Hasten not, stay, $O$ friend of thought.

See, she remains, only clouds wandered their way.

The waking of May is alone

fairer still than the summer night, when the dew, bright as light, from her ringlets falls and, cheeks aglow, she ascends over the hill.

You noble ones, now the dark moss grows on stones which were carved for you. O how glad was I then, when I shared with you reddening gleams of the dawn, shimmering nights. 
(Wenn der Schimmer von dem Monde nun herab)

This poem and the preceding one are the only odes of Klopstock in which the aim of the poet is to present lyrical, impressionistic pictures, rather than ideas or strong emotions. Here the mood is muted, lingering in a twilight zone between joy and sadness.

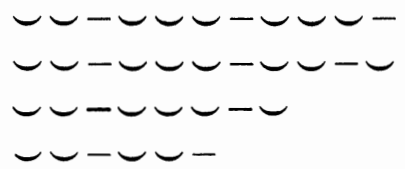

When the lustre of the moon now overflows into forests far below and aromas with the fragrance of the linden in the breeze float away,

recollections hover near me of the grave of my darling and I see in the forest only twilight, and the odor of the blossoms is gone.

I enjoyed it, dear departed, once with you.

How the fragrance and the breeze drifted past us, how the moon brought out your beauty, $\mathrm{O}$ most beautiful land!

\section{MY GROVE}

"My Grove" was written many years after the preceding poems, when Klopstock was approaching old age. It was composed for a friend who had entertained him for several days and describes a park on the friend's country estate.

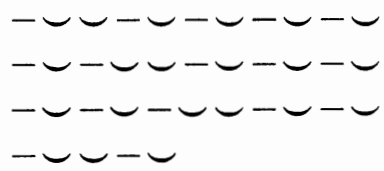

Oaks of my lovely grove, your cooling shadow long has given relief. I sank no roots for these exalted tree-tops, for you were growing sooner than I, but 
youths are you still, will stretch forth high and higher yet your heads and will throw, when day is waning, longer shade. Be green then when I am gone; I envy you not, oaks.

\begin{abstract}
And I shall plant beneath you noisy playmates, weeping willows, that sometime in your darkened forest depths, breathed through by the evening breeze, their foliage may softly

sound as it trembles and a winsome lover tell his maiden: it weeps not though it murmurs, babbling music, maybe an ancient fable told by our fathers.
\end{abstract}

When from the storm the oaks no longer thunder, when no whispers are heard from wind-blown willows, still will songs be, coming from deepest feeling, calling the spirit.

Matthias Claudius was born in the parsonage of the village of Reinfeld, in South Holstein. He received his early education from his father and later studied first theology, then law, at the University of Jena. Here he was repelled by the barren Rationalism into which the Enlightenment was beginning to deteriorate, and composed several poems ridiculing utilitarianism. After completing his studies, he became a journalist in the country town of Wandsbek. $\mathrm{He}$ was a pious man, but one who put more faith in moral actions than in theological creeds, and much of his journalistic writing was covertly didactic. He strongly attacked Voltaire and the frivolous spirit of the French, and praised such natural geniuses as Shakespeare, Ossian, and Homer. The early writings of Claudius are representative of the Enlightenment, but as he grew older, he became more conservative, and finally rejected reason as the central force of life and nature.

The songs of Claudius are full of humor and almost peasant simplicity. He lived close to nature, spent his life in a village, and disliked being in cities. $\mathrm{He}$ felt a close kinship with forests and gardens, fields and meadows, and his nature poetry is more realistic than that of any of his predecessors. His language and verse structure are simple and show a close affinity to those of the folksong. His prevailing mood is optimistic and confident. 
(O wie schön, wie schön ist der Mai)

This poem belongs to the early verse of Claudius, which was strongly influenced by Klopstock. It differs greatly in style from the simpler and more realistic verse of his mature years.

O how fair, how fair is the May!

Grass and flowers are growing,

forests spread their foliage,

gently blow the breezes, grazing bullocks wander, infant lambs are bleating.

$\mathrm{O}$ how fair, how fair is the May!

See this lovely meadow!

Leaves of grass in thousands!

From each blade are hanging

silver drops of dew.

How the cowslips cluster

closely here together!

How the green leaves rustle!

And on the distant hillside

sings the nightingale.

Round about is gladness;

gladness on the hillside,

in the valley gladness,

gladness in the thicket,

gladness on the tree-top;

all is life and feeling.

$O$ how fair, how fair is the May!

Were but Daphne with us!

Blow winds gentle breezes!

Flowers share your fragrance, and I now shall gather

carefully the fairest.

I'll not harm the flowers,

I'll not lose the dewdrop,

and with cheerful greeting

give the blooms I've gathered, stand beside her, watching, 
as she weaves the garlands, as she chooses from them that which is most fitting, winds it round her forehead, sends then friendly glances from the flower garland.

Were but Daphne with us! And from all the grasses dangle drops of dew, and the bullock grazes, and the flowers are blooming, and the leaflets rustle, and the lambs are bleating, and on the distant hillside sings the nightingale.

THE MOTHER BY THE CRADLE

(Schlaf, süsser Knabe, süss und mild)

The domestic theme of this poem, its sincere sentiment, mild humor, and simple form make it typical of most of Claudius' verse. His several lullabies are among his best known poems.

Sleep, darling boy, so sweet and mild, your father's joy, his own true child. You look like him, though he declares your nose is not the one he wears.

He just was here, and thoughtfully he murmured, "I suppose the chin and eyes he got from me, but that is not my nose."

I think so too, it's far too small, it almost is no nose at all, but, if the nose is counterfeit, just where could you have gotten it?

Sleep, child, what father says of you, he only speaks in jest.

Though you don't have his nose, it's true, his heart is in your breast. 


\section{DEATH AND THE GIRL}

(Vorüber! Ach, vorüber)

The almost unassailable optimism of Claudius is seen in this cheerful picture of death.

Girl. Pass by! O pass me by!

Away, wild mask of death!

I still am young! $O$ why

destroy me with your breath?

Death. Give me your hand, you lovely, tender child;

I am your friend and bring no harm.

Have courage. See, I am not wild;

now go to sleep upon my arm.

\section{A SONG TO BE SUNG BEHIND THE STOVE}

(Der Winter ist ein rechter Mann)

The realistic descriptions of farmers crowding around the stove and the sounds of the fox, of the frost, and of the ice cracking on the river mark the poet as a forerunner of the local color writers of the nineteenth century.

Old Winter's resolute and hale and tough as any leather; his flesh is like a coat of mail, he fears no wind nor weather.

No man is healthier than he; he never coughs nor sneezes, his stomach's sound as it can be although his bedroom freezes.

He dresses in the open air and never by the fire, but has no ailments anywhere despite his chill attire.

For flowers and the songs of birds he has no taste nor notion; he hates warm sights and hates warm words, warm sounds and warm emotion. 
When foxes bark and cease to rove, when snow-bent branches quiver, when farm-folk huddle round the stove and rub their hands and shiver,

and when the frost breaks stones and bones, the river cracks and crackles, he hears with glee the icy tones and cocks his ear and cackles.

In polar ice his castle lies, with frozen parks and fountains; a summer home he occupies in Switzerland's fair mountains.

And so he goes from land to land his profits to assemble, and when he passes through we stand and look at him and tremble.

\section{CHRISTIANE}

(Es stand ein Sternlein am Himmel)

This poem and the one which follows were written at the death of the poet's daughter, Christiane.

A star stood in the heavens, a little, charming light, that always shone so sweetly, so softly through the night.

I knew the stars around it and where its place should lie and sought until I found it in every evening sky.

I used to watch it yonder, so dainty and so far, and, filled with joy and wonder, I thanked God for the star.

The star has vanished, vainly I seek it from my door, but where I saw it plainly, I find it now no more. 
(Ach, es ist so dunkel in des Todes Kammer)

O, it is so dark in Death's cold room!

It rings so harshly, sadly, as with power his heavy hammer flashes in the gloom and strikes the hour.

\section{LUDWIG HÖLTY (1748-1776)}

Ludwig Hölty, like his friend Claudius, was primarily a poet of nature and rural life. He grew up in the village of Mariensee, near Hannover, and learned to know the farmers, their way of thinking, and their joys and sorrows. At the age of eight an attack of smallpox left Hölty disfigured and broken in health. Not being able to participate in the normal activities of a boy, he retreated to the books and study which remained his refuge throughout his short life. At the University of Göttingen he was such a diligent student that the mastered seven foreign languages and became well-informed in history, philosophy, and literature, while carrying on his major work in theology. Poor health made it impossible for Hölty to accept a pastorate, and after his student years he remained on in Göttingen, supporting himself by tutoring and translating. After several years of extreme poverty and over-exertion, he died of consumption at the age of twenty-nine.

For all his learning, Hölty's themes are limited, and his thought is not profound. But his poetry is distinguished by purity of form and freshness of expression. Although he often writes in an anacreontic vein, his prevailing tone is of mild melancholy. This mood, his enthusiasm for the Middle Ages, and his tendency toward dream pictures and phantasy, stamp him as a forerunner of the German Romantic movement.

\section{MAY SONG}

(Der Anger steht so grün, so grün)

The second stanza of this spring song well illustrates the doctrine of the Enlightenment, that all natural phenomena were created by a beneficent God solely for the use and pleasure of man.

The meadow lies so green, so green

the violets cast a purple sheen, the cowslips sparkle gaily.

The valley's face

in every place

is painted brighter daily. 
So come, all you who love the spring, enjoy what field and forest bring, the gifts his goodness showers, who graced with pride the countryside with grass and trees and flowers.

\section{TO THE EVENING STAR}

(Heil dir, Hesper! mit dem milden Antlitz! Blinkest)

Although Hölty lived close to nature, much of his nature poetry, including these verses, reflects his personal experience less than it does the vogue of somewhat artificial pastoral poetry which was so prominent in Western Europe and England during the eighteenth century.

Hail, Hesperus, whose gentle face is blinking in the painted evening heavens! Are you winking to the youth and maiden in the wood below, saying, "Kiss before you go."?

Kisses murmur through the graying dusk so sweetly that ecstatic forest goddesses discreetly listen as they eye the youth with shameless lust and the maiden with distrust.

So the lovers pass, embracing ever fonder, through the moonlit shadows silently they wander. With delight their breathing labors as with pain; rapture burns in every vein.

Springtime roses, spread the fragrance of your dresses, as the evening wind your youthful breasts caresses; whisper, brooks, through darkened glades and trees ever sweeter melodies.

Pour forth, nightingale, your fairest, brightest fancy, all your magic spells and secret necromancy; smile, O Hesperus, through vaults of leafy lace temptingly with each embrace. 
(Birg, O Veilchen, in deinem blauen Kelche)

Shortly before Hölty went to the University of Göttingen he fell in love with a beautiful girl, Anna Juliane Hagemann, who appears in his songs under the names of Daphne, Laura, and Juliane. Although he immortalized her in his verse, the poet could never bring himself to tell her of his love. She is the Rosaura (Rose-Laura) of this ode.

Hide, $\mathrm{O}$ violet, in your purple calyx, hide my tears of sorrow, till Rosaura finds this gleaming fountain. Should the maiden pluck you from the grass to deck her bosom, nestle to her breast, there lie and tell her how the drops you gathered in your petals issued from a loyal heart, from one who weeps his life and seeks for death with longing.

\section{HARVEST SONG}

(Sicheln schallen)

Few poets have caught the festive spirit of harvest time so completely as Hölty has in this song. The short line is particularly effective in dramatizing the quick, joyful activity.

Sickles calling, ears are falling to the sickle's sound. Every maiden's bonnet has a blossom on it, joy is all around.

Sickles swinging, girls are singing while the sickle croons till the moonlight shimmers, till the stubble glimmers happy harvest tunes.

All move lightly, lilting brightly, workers, strong and able. Man and master meet then, from one dish they eat then at the grassy table. 
True and fickle whet the sickle, whistle a refrain.

Now they mow, each binder ties and leaves behind her golden sheaves of grain.

Laughing faces, fond embraces, foaming mugs of beer.

Homeward now they wander to the village yonder singing loud and clear.

\section{THE CUP OF FORGETFULNESS}

(Eine Schale des Stroms, welcher Vergessenheit)

The exalted language and the variable rhythms of this ode reveal the influence of Klopstock. At the same time there is a strong general resemblance to the "Storm and Stress" verse which the young Goethe was writing at this time.

One cup from the stream, where flows oblivion through Elysium's blooming flowers, one cup from the stream, grant me, $O$ genius! There, where Sappho forgot her youth, there where Orpheus forgot his Euridice, there fill the golden urn.

Then your image shall sink, mistress imperious, in that shimmering well of sleep!

The all-conquering glance, thrilling each vibrant nerve, and the tremor of snowy breasts, and the beautiful music which flowed from your lips I shall plunge in the well of sleep. 


\section{GOETHE}

Johann Wolfgang von Goethe (1749-1832) is generally acclaimed not only as the outstanding German poet, but also as one of the greatest and most universal geniuses of all time. Though he ranks with the foremost of German writers in each of such diverse fields as the lyric, the ballad, the novel, the short story, drama, autobiography, and history, his literary activity represents only one aspect of his genius. For he also produced scientific works on botany, geology, physics, and physiology, and proved himself to be an able statesman and administrator of governmental affairs.

Goethe was born in the city of Frankfurt, studied at Leipzig and Strasbourg, then settled in Weimar, the capital of the little duchy of Saxe-Weimar. His long career as a poet spans the historical period from the Seven Years' War through the French Revolution, the Napoleonic Wars, and the democratic revolutions of 1830 . It embraces a literary period which extends from the middle of the Age of Reason to the end of Romanticism and the beginning of nineteenth-century Realism. Goethe's earliest verse is characterized by a playful rococo superficiality and reveals more ingenuity than depth of thought or feeling. His true poetic development began when he was a student at the University of Strasbourg. Here he was caught up in the violently rebellious literary movement known as Storm and Stress.

The Storm and Stress Movement was neither widespread nor of long duration, but for some poets it served to clear the air of the stale and uninspriring rationalism of the latter half of the eighteenth century. The well-ordered universe of the Enlightenment was renounced, along with its sometimes shallow optimism, its moderation, its emphasis on good taste, and its restrictions on literary expression. The Storm and Stress poets loudly proclaimed the supremacy of the unrestrained, individual genius and poured forth highly emotional works which flouted all accepted literary and social conventions. They praised nature, denounced culture, and idealized the folksong as the voice of natural man. But Storm and Stress was essentially a youthful phenomenon, and Goethe soon outgrew it. After his arrival in Weimar, in 1775, he became a minister in the government, and the pressure of practical, mundane activities showed him the necessity of coming to terms with the social order in which he lived. At the same time a long and hopeless love for a married lady of the court, Frau von Stein, taught him renunciation.

The most important influence upon the mature Goethe was exerted by 
Italy, where Goethe spent the years from 1786 to 1788 . These years mark the beginning of his classical period with its preoccupation with antique literature and art. Inspired by Greek culture he began to seek the unity of nature and existence and to look beyond the temporal and occasional to find eternal, representative truths. He wished his works to illustrate the antique ideal which has been phrased as "noble simplicity and quiet grandeur." Although Goethe never identified himself with the Romantic Movement, which began toward the end of the eighteenth century, he was to a certain extent influenced both by its literature and by its Weltanschaung. Much of the lyric poetry of his old age is essentially romantic in nature, as is particularly evident in the magnificent oriental verse of the West-East Divan.

Although Goethe's verse developed and changed during his sixty-odd years of serious literary activity, its most prized characteristics - simplicity, conciseness, and universality - were present from the beginning. His language is unique in its directness and naturalness, and his tone is so relaxed and conversational that the reader often loses the poem in the subject. The poem ceases to tell of an experience and becomes the experience. The simplicity of his language and style is matched by his subjects. His favorite themes are love, nature, and the elemental, universal problems of humanity. These themes are not treated abstractly, but rather as they appear in familiar and concrete phenomena. Goethe realizes that individual human experiences are uncomplicated, that complexity is not a characteristic of experience, but of the contemplation of experience. His verse is subjective, but the subjectivity is such that the reader can readily take the place of the author and claim for himself the experience described.

THE SONG OF MOHAMMED

(Seht den Felsenquell)

The poem was originally intended to be included in the unfinished drama, Mahomet, as an antiphonal song in praise of the prophet, sung by Ali, his follower, and Fatema, his daughter. It is symbolic of the growth and spread of a great idea - Islam. The Storm and Stress poets believed that if great verse were to be written in their generation, it would have to be composed in the dynamic, free rhythms of primitive poets.

See the mountain spring,

bright with joy,

like a starry light!

Over cloud-banks

kindly spirits

nursed the happy baby

in the rocks and bushes there. 
As a boy

from the clouds he dances

to the marble crag beneath them, then leaps upward

with rejoicing.

Through a lofty crevice

chases gaily-colored stones

and with youthful sovereignty

sweeps along his brother-streamlets

as he goes.

In the valley far below

flowers spring up from his footsteps

and the meadows

flourish with his breath.

But no shady glen beguiles, nor the blossoms

which may bend about his knee, look at him with loving glances, for his course is toward the plain, snake-like winding.

Other brooks now

nestle to him, and he enters

silver-sparkling in the lowland, and the lowland sparkles with him, and the rivers of the lowland and the brooks from off the mountain shout with joy and call: "My brother! Brother, take your brothers too with you to your ancient father, to the ever-lasting sea, who with arms outstretched in greeting now awaits us, arms which, $\mathrm{O}$, in vain are open to embrace his longing children: for the greedy sand devours us and the desert sun above us sucks our blood, and there a hillock hems us to a pool. $\mathrm{O}$ brother, take your brothers of the lowland, take your brothers of the mountain with you to your father's arms!" 


\begin{abstract}
"All shall join me."
And he rises

splendidly: a race of waters

bears its lordly prince on high.

And in triumph he advances

giving names to lands, and cities

come to being in his path.
\end{abstract}

Irresistibly he rushes,

leaves the flaming tops of towers, marble houses, a creation

of his fullness, all behind.

Cedar ships the Atlas carries on his giant shoulders; banners rustle in the breeze by thousands, far above his head they flutter, giving witness to his might.

So he bears his smaller brothers, bears his treasures and his children joyfully to the creator, to the waiting father's breast.

\title{
PROMETHEUS
}

(Bedecke deinen Himmel, Zeus)

Goethe's Storm and Stress Titanism reaches its peak in this poem. It was composed as an introduction to a drama, Prometheus, which he never completed.

Overcast your heavens, Zeus, with flimsy clouds and flex your muscles, like a boy beheading flowers, on oaks and mountain tops; this spot of earth you cannot rule, nor this small hut, which you did not erect, nor this my hearth whose glow and heat you envy me. 
I know nothing shabbier

under the stars than you, you gods,

who nourish wretchedly

with offerings

and breaths of prayer

your majesty,

who would starve, were not

children and beggars

hopeful fools.

When I was a child

and knew not where I should turn,

I lifted my erring eye

to the sun, as if up there

were an ear to hear my lament,

a heart like mine

to feel pity for the afflicted.

Who helped me

thwart the Titans' arrogance?

Who saved me from destruction then,

from slavery?

Did you not do it all yourself, my sacred, glowing heart?

And glowing, young and good, deceived, you thanked

the sleeping one up yonder.

I honor you? For what?

Have you relieved the pain

of the heavily burdened?

Have you appeased the tears

of the anxious and fearful?

And was I not formed to a man

by omnipotent time

and eternal fate,

your masters and mine?

Did you fancy perhaps

I would hate this life

and flee to the desert

because all my blossoming

dreams did not ripen? 
Here I sit, forming men

in my own image,

a race to be like me, to drink and rejoice, to suffer and cry, and pay you no heed, as do I.

THE SON OF THE MUSES

(Durch Feld und Wald zu schweifen)

The sensitivity, the mission, and the isolation of the poet are the themes of this poem. In the spirited musical setting of Schubert it is perhaps the most popular of all Wanderlieder.

Through field and wood to wander, my merry songs to squander, I pass from place to place.

And, pouring forth my treasure and moving with the measure, I dance with airy grace.

I wait through wind and weather for blooms among the heather, for blossoms on the trees.

They hear my songs with gladness, and with the winter's sadness I'll sing and dream of these.

I'll sing them in the mountains by frozen streams and fountains where winter blooms so fair. These flowers too shall wither, but new delights come hither and I shall have my share.

For soon am I surrounded when first my notes have sounded beneath the linden tree by clumsy bumpkins skipping and comely maidens tripping to dance my melody. 
You wing my soles to wander and lead me here and yonder away from home and bride. O Muses, weary, lonely. I long for rest, with only my sweetheart at my side.

\section{VACILLATION}

\section{(Feiger Gedanken)}

The heroine of Goethe's operetta, Lila, has fallen into a fit of temporary insanity as a result of the false report of her husband's death. The verses are sung by a magician in an attempt to cure her. The effect of an incantation is admirably produced by the short, staccato line.

Cowardly quavering, timorous wavering, womanish quailing, faint-hearted wailing wards off no sorrow, leaves you afraid.

Never to cower before any power, ever undaunted, by no terror haunted calls down the arms of the gods to your aid.

\section{LOVE}

(Freudvoll und leidvoll)

One of the most delightful of Goethe's characters is Klärchen, the young mistress of Count Egmont in the drama, Egmont. The one significant fact of Klärchen's existence is her love, which she attempts to describe in this song.

Cheerful

and tearful, reflective and tense, longing and thronging 
with anxious suspense,

shouting in rapture

to heaven above -

happy alone

is the one who's in love.

\section{WANDERER'S NIGHT SONG I}

(Der du von dem Himmel bist)

The unrestrained egotism which produced the Titanism of Storm and Stress also produced the Weltschmerz of Goethe's novel, Werther, and of this poem. The verses were written on a mountain side near Weimar and sent to Frau von Stein.

Thou who from the heavens art, stilleth every pain and grief, and the doubly wretched heart doubly filleth with relief, $O$, I weary of contending! Why this longing and unrest? Peace, descending, come, $\mathrm{O}$ come into my breast.

\section{WANDERER'S NIGHT SONG II}

\section{(Ueber allen Gipfeln)}

Once while in his middle thirties, Goethe climbed the slope of the Gickelhahn Mountain in the Thuringian Forest in order to find the solitude he required for the composing of a poem in honor of the Duke of Weimar's birthday. There on the rough wooden wall of a summer cottage he wrote this poem. As an old man he climbed the mountain again with a group of friends and found the lines he had written almost a half century before. With deep emotion he read them aloud, repeating with emphasis the concluding words.

Over the mountains now quiet reigns, and in the top-most bough remains scarcely a breeze;

the birds in the forest are still.

Wait, soon you will slumber as these. 
(Füllest wieder Busch und Tal)

In the original version, composed when Goethe was twenty-eight, the poem was a declaration of love for Frau von Stein. Later Goethe revised it to give this less personal and more universal tone. The moon is a distant friend who sends a glow to give comfort to the lonely wanderer. The stream is time which leads the loneliness of the first stanzas over into the enjoyment of true friendship of the last stanza.

Filling thicket, field, and glen with your misty gleam, freeing from my heart again every secret dream;

spreading over house and land soothingly your glance, as a comrade's gentle hand over fate and chance.

Happy echoes now I hear, now of deep distress, walk between delight and fear in my loneliness.

Flow on waters, ever flow; joy I'll never see; jests and kisses vanished so, as did constancy.

Memories I cherish yet are so sweet and fair; these I never can forget, though they bring despair.

Madcap river, rush along, leaving rest and ease; murmur, whisper to my song lovely melodies

when on winternights you fling waters forth in floods, or move gently in the spring past the blooms and buds. 
Happy he who, without hate, leaves the world behind, with a friend to watch till late in the glen to find

what (by others never guessed, or not learned aright)

through the labyrinth of the breast wanders in the night.

\title{
HUMAN LIMITATIONS
}

\section{(Wenn der uralte)}

This poem is a renunciation of Titanism and marks the end of Goethe's youthful Storm and Stress. In "Prometheus" the defiant rebel against the gods admits no limitation to human aspiration. Here humility replaces defiance, and the individual becomes significant only as a link in the endless chain of human existence. This chain, however, is by implication of the greatest importance, for only through it does divinity have being and permanence.

\author{
When the primeval, \\ heavenly father \\ with deliberate hand \\ from thundering clouds \\ beneficent lightning \\ sows on the earth, \\ I kiss the lowest \\ hem of his garment, \\ child-like allegiance \\ thrilling my breast. \\ For with immortals \\ no human being \\ ever compares. \\ If he rise upward \\ touching the distant \\ stars with his head, \\ where shall his wavering \\ feet have support? \\ With him shall trifle \\ the clouds and the winds. \\ If he with sturdy, \\ vigorous members \\ stands on the solid,
}


permanent earth, he will not reach to the crown of an oak, nor with a grape-vine measure himself.

What then distinguishes men from immortals? Waves without number wander before them, eternal and vast;

a wave lifts us skyward, carries us downward, and we are gone.

A tiny ring limits our life; they string unceasingly ages and races on their existence's unending chain.

\section{THE HARPER'S SONG}

\section{(Wer nie sein Brot mit Tränen ass)}

This song is sung by the mysterious, half-mad harper in Goethe's novel, Wilhelm Meister's Apprenticeship. The harper has cause to bewail his fate, for he has lost everything and is burdened with guilt because of a crime (incest) committed unknowingly. The poem may be interpreted as a protest against the optimism of the Enlightenment.

Who never ate his bread with tears, who never sorrowed painful hours upon his bed with anxious fears, he knows you not, you heavenly powers.

You lead us into life, and chain us wretched ones with guilt at birth, and then you leave us to our pain, for guilt is punished here on earth. 


\section{(Kennst du das Land, wo die Zitronen blühn)}

The poem appears as a song by Wilhelm Meister's ward, a young girl, who was stolen away from her home at an early age by gipsies. With deepest longing she recalls the sunny landscape of her native Italy, her father's house, and the perilous journey over the mountains to Germany. The different modes of address reveal the tragic ambiguity of her feelings toward Wilhelm Meister. In the poem Goethe also expressed his own passionate desire to go to Italy, a desire that soon became so strong that, without warning, he gave up all his official positions and, telling only the monarch of his plans, hurried over the mountains to the fabulous land of antique culture. With regard to diction, the poet uses many of the conventional pictures and phrases of the prevailing anacreontic verse, devices which he usually scorned to employ.

Do you know the land where citron blossoms blow, in leafy groves the golden oranges glow, and breezes lightly drift along the sky, where myrtle teems and laurel towers high?

Do you see it now? O there I know

I would with you, $\mathrm{O}$ my beloved, go.

Do you know the house? It stands with columns tall, with glistening rooms and gleaming banquet hall; and marble statues look with glances mild:

what have they done to you, poor lonely child?

Do you see it now? O there I know

I would with you, $\mathrm{O}$ my protector, go.

Do you know the pass, and know the mountain gray?

The weary mule seeks through the mist his way, in caverns dwells the dragon's ancient brood, the boulders fall and over them the flood.

Do you see the path? O there I know must lie our way. $\mathrm{O}$ father, let us go.

\section{SONG OF MIGNON II}

\section{(Nur wer die Sehnsucht kennt)}

These lines which Mignon sings to the accompaniment of the harper give expression not only to her own longings, but also to the yearning of Wilhelm for a lady who had saved his life and then vanished. An added significance of the poem can be seen in the fact that Goethe enclosed it in a letter to Frau von Stein. 
Only the yearning heart can know my sadness. Lonely and set apart from all of gladness, I look to east and west: can he be near me? Ah, he who loves me best now cannot hear me.

My head is faint; I burn, dreading tomorrow.

Only the hearts that yearn can know my sorrow.

\section{ADMONITION}

(Willst du immer weiter schweifen)

Goethe's reputation as a philosophic poet is based to a large extent on the many short, aphoristic poems, such as this, which he wrote during the latter part of his life.

Will you always rove and wander?

See, good fortune lies so near.

Why pursue enjoyment yonder?

Only learn to seize it here.

THE PRESENCE OF THE LOVED-ONE

(Ich denke dein, wenn mir der Sonne Schimmer)

Goethe's skill in using concrete symbols and situations to bring out an abstraction is particularly apparent in this poem, where the sensual perceptions of "I see you," "I hear you," "I, too, am there," intensify the abstraction of "I think of you." The speaker is a girl.

I think of you when from the restless ocean the sunlight beams, and when the moon reflects with liquid motion from rippling streams.

I see you there, when on the distant highway a dust-cloud nears; in deepest night when on the mountain byway the traveller fears. 
I hear you where the waves with muffled thunder their waters spill, and listen in the silent grove with wonder when all is still.

I, too, am there - however far you wander where you may be;

the sun goes down, a single star blinks yonder. $\mathrm{O}$, come to me.

\section{THE QUIET OF THE SEA}

\section{(Tiefe Stille herrscht im Wasser)}

The poem describes the horror produced by the complete absence of sound or motion. Goethe's only experience on the open sea was during a crossing from Italy to Sicily in 1787.

Deathly quiet rules the water, deep in slumber rests the sea, polished silver greets the sailor, looking round him fearfully. Not a whisper, not a motion, just the silence of the grave, and throughout the boundless ocean ripples not a single wave.

\section{A HAPPY CROSSING}

(Die Nebel zerreissen)

The poem was probably inspired by the same experience and written at the same time as that above. The nature of "the ominous band" which Aeolus loosens is not clear. It could be the band which keeps the winds in check or, with reference to the preceding poem, the invisible band which keeps the ship motionless.

The mists now have lifted, the heavens are shining, and Aeolus loosens the ominous band. The winds murmur lightly, the boatman awakens. $\mathrm{O}$ hasten, $\mathrm{O}$ hasten! The keel parts the water, the harbor approaches, I see there the land. 


\section{(Sagt es niemand, nur den Weisen)}

In the years 1814-15 Goethe wrote his West-East Divan, a collection of verse which was to combine the virtues of Western and Eastern philosophies. The theme of this poem from the Divan was suggested by the fourteenth-century Persian poet, Hafis. The human soul as a moth is consumed by the flame of love, but the yearning of the soul is not merely for human love, but for reunion with divinity. A new life follows in the endless chain of reincarnation.

Tell it only to the sages, since the rabble jeers and blames: I would praise upon these pages life that seeks for death in flames.

In the cooling shade, concealing mating, procreating nights, comes an unfamiliar feeling when the silent candle lights.

Shadows hold you now no longer, nor the black of night, unseeing, for the urge is ever stronger toward a higher love and being.

And you flutter, moth, elated to the goal of your desire, till at last your lust is sated in the fury of the fire.

If you do not have this quest: death, and then rebirth! you remain a gloomy guest on a darkened earth.

\section{PERMANENCE IN CHANGE}

\section{(Hielte diesen frühen Segen)}

The permanence of change was a favorite concept of Goethe's later years. He saw all phenomena not as in a state of being, but as in a state of becoming: of death, rebirth, and transformation. In the first two stanzas of the poem we see the changing face of nature. The next two stanzas reveal that the poet too is subject to change and death. The last stanza declares that only the creations of the human spirit have permanence. 
O, if only for an hour springtime's beauty could remain, but a fragrant blossom-shower falls before the wind and rain. When the grass and foliage pleases, gives a couch and cooling shade, winter's frost soon comes and freezes every leaf and every blade.

Gather quickly, when securing what you share of summer's fruits, for while some are still maturing, others then have started shoots. And when stormclouds shake and quiver change will seize your lovely glen; $\mathrm{O}$, and in the selfsame river you will never swim again.

So with you! What, long-enduring, towers timeless in the sky, this you see, but still obscuring all with ever-changing eye.

Gone are lips that whispered pledges, kissed with mingled joy and fear, feet which on the rocky ledges rivaled those of mountain deer.

Hand and arm and every feature: youthful eyes, unwrinkled brow, each component of this creature has become another now. That, which (still in endless motion) answers to your name, was sent as a wave upon the ocean soon to join its element.

Let the end with the beginning draw together into one quicker than the objects, spinning past you, reach oblivion.

Thank the favor of the muses for an artist's heart and brain that can fix what now diffuses into form which shall remain. 


\section{SCHILLER AND HÖLDERLIN}

Friedrich Schiller was born in Marbach, a small town in Württemberg, and received his education at the state military school in Stuttgart. After graduation he became a regimental surgeon in the Württemberg army. Schiller had not chosen a military career but had been forced into it by a tyrannical monarch. He was unhappy in his position, deserted after one year, and became a refugee from his homeland. The years that followed were marked by disappointments, privations, and sickness, and the poet would hardly have survived had it not been for the assistance of his friends. After brief residences in Bauerbach, Mannheim, Leipzig, and Dresden, Schiller settled down in Jena as Professor of History at the university. Twelve years later, at the suggestion of Goethe, he received a stipend from the Duke of Saxe-Weimar which enabled him to move to Weimar and devote himself entirely to literary pursuits.

The bulk of Schiller's poetry was composed while he was at Jena, at a time when he was particularly engrossed in the study of philosophy. This study is reflected in the philosophic quality of his verse: the tendency to write about ideas rather than things, the intellectual approach to his subject, and the interpretation of beauty as being essentially moral in nature. The other important characteristics of Schiller's poetry, its rhetorical outbursts and dramatic and impersonal quality, stem from the fact that Schiller, whether writing poems or plays, was primarily a dramatist.

\section{POESIE}

(Mich hält kein Band, mich fesselt keine Schranke)

These verses are spoken by Poesie in the dramatic poem, "Homage to the Arts." The emphasis on thought rather than feeling and the use of abstract concepts rather than concrete symbols is characteristic of much of Schiller's poetry.

No bonds can hold, no bounds can hem my flight, I soar through space as freely as a bird; my endless realm is thought, my throne is light, 
my winged sceptre is the living word.

All things which move in heaven and on earth

must lift their veils and break their seals for me,

and all which nature secretly gives birth

is subject to the power of poetry.

Yet nothing can I find more fair and warm

than the lovely soul within the lovely form.

THE STRANGE MAIDEN

(In einem Thal bei armen Hirten)

"The Strange Maiden" is atypical among Schiller's better-known poems in that it is essentially lyrical rather than dramatic. The language is simpler, the rhythm more musical, and the mood quieter than is characteristic of the author. The strange maiden can be interpreted as the spirit of poetry that wanders through the world, giving flowers of pleasure and fruits of high ideals. Though all share her gifts, the best is reserved for lovers, for love is itself poetry.

To shepherds in a mountain glade appeared with each returning spring a wonderful and lovely maid, when first the larks began to sing.

She was not of the mountain race and whence she came no one could say; when she departed, not a trace could tell them where had wound her way.

Her presence was delight, for she made hearts grow warm and spirits tall; yet, what was almost majesty commanded reverence from all.

She brought them wondrous fruits and flowers, but these had grown in other fields and under milder suns and showers; such fruits a kinder nature yields.

Each villager received a share; the happy youth was blessed, and he whose ancient head was bowed with care trudged homeward smiling joyfully.

She welcomed every rustic guest, but, if a pair of lovers passed, she gave to them her very best; each blossom brighter than the last. 


\section{THE MAIDEN'S LAMENT}

\section{(Der Eichwald brauset)}

The setting for the poem was suggested by a group of English folksongs which Schiller read in translation. It was written while Schiller was preparing his drama, Wallenstein, and two of the stanzas below appear in the drama. The "Holy One" of the second stanza is the Virgin Mary.

The clouds are racing,

the forests roar;

the maiden is sitting upon the shore.

The breakers are crashing with might, with might, and she breathes a sigh to the darkening night; her eyes have been saddened with weeping:

"The world now is empty, my heart is sore, my passionate wishes are granted no more.

You Holy One, take me from pain and distress, for I have tasted earth's happiness, its love and its ecstasy reaping."

"In vain you bewail him, no tears you have shed, no weeping will ever awaken the dead.

But say what will help you and lighten your breast, replacing the joy of the love you possessed, and the Virgin will grant it tomorrow."

"O let them flow freely, these tears that I shed, though weeping can never awaken the dead, the sweetest relief for the desolate breast, replacing the joy of the love it possessed, is the anguish of love and its sorrow.

\section{LAMENT}

(Auch das Schöne muß sterben! Das Menschen und Götter bezwinget)

The poem is a by-product of Schiller's preoccupation with the nature of beauty. He saw in beauty the result of the perfect union of natural and moral laws. This beauty, toward which 
all men strive, can be achieved only through the power of the poet's imagination, and even then it is transitory. Lines 3-4 refer to the laments of Orpheus which moved Hades to give back Eurydice, under the condition that Orpheus not look back at her as he left the underworld; since Orpheus did look back, Eurydice had to return. Line 9 describes a scene which is spoken of in the twenty-fourth Book of the Odyssey.

Even beauty must die! What conquers both men and immortals softens not the iron breast of the Stygian Zeus.

Only once did love move the ruler of Hades then, at the very threshold, sternly he called back his gift. Aphrodite heals not the wound received by the lovely Adonis when his graceful form was savagely torn by the boar. Nor is heroic Achilles saved by his mother, a goddess, as by the Scaean door, falling, he yields to his fate.

But she ascends from the sea with all the daughters of Nereus and begins the lament over her glorified son.

See the tears of the gods, and all of the goddesses weeping, weeping that beauty should pass, and that the perfect must die. This, too, is splendor, to be a dirge in the mouth of a loved-one, for the unworthy go down into Orcus unsung.

\section{EVENING}

(Senke, strahlender Gott, die Fluren dürsten)

Phoebus Apollo, the sun god, drives his fiery chariot down from the sky for a meeting with Tethys, a Titaness and wife of Oceanus. This poem, as well as the preceding one, reveals something of Schiller's great interest in classical literature and mythology.

Sink, irradiant god, the fields are thirsting for the comforting dew, and men are fainting, weakly struggle your horses let your bright chariot descend.

See her, who from the ocean's waves of crystal smilingly beckons to you. Your heart discerns her. Swiftly hasten the horses; Tethys, the goddess, is she.

Quickly down from the chariot springs the driver (Cupid seizes the reins) and soon he holds her, Quietly the tired horses drink from the fresh, cooling flood. 
Up the evening sky with silent footsteps

mounts the sweet-scented night; behind her follows

Love. $O$ rest now and love now!

Phoebus, the lover, shall rest.

\section{MOUNTAIN SONG}

(Am Abgrund leitet der schwindlichte Steg)

This poem is one of the products of the careful study of Switzerland which preceded the writing of the drama, William Tell. It is a tribute to the power of the poet's imagination that he can describe here so vividly a scene which he never saw. The poem describes a path along the Reuss River leading to the St. Gotthard pass. The other rivers which have their source in this area are the Ticino, the Rhine, and the Rhone. The giants are huge boulders, and the lion is the avalanche. The two peaks are probably those which rise above the Hospice of St. Gotthard; the queen is a snow-covered peak, the Mutthorn.

The pathway clings to the precipice wall and passes from danger to danger;

It's guarded by giants, enormously tall, which threaten the wandering stranger.

And who would not waken the lion that dwells on the height will walk softly this highway of hells.

The fearful depth of the chasm is spanned by an arch that hangs in the sky, a bridge not constructed by human hand; no man would have ventured so high.

The torrent roars underneath early and late, but the bridge is untouched by its violent hate.

A dark passage opens, a gateway of fear, as if to the Kingdom of Shadows, but through it the fruit-laden orchards appear and spring flowers grow on the meadows. From life's heavy trials and infinite woe I long to escape to this valley below.

From hidden springs the waters are hurled: four rivers stream down from the crest; they flow toward all the four streets of the world, to the east, north, south, and the west. With the fury and speed of their turbulent birth they flee from the mountain to water the earth. 
In the blue of the sky two pinnacles raise their peaks over meadows and waters, and on them, veiled with a golden haze, dance the clouds, the celestial daughters. They dance high above in that atmosphere chill; no human can join in their lonely quadrille.

The queen is sitting so high and clear on a changeless, ageless throne; she wreathes her forehead from year to year with many a precious stone.

The warm sun assails her with shafts of gold which gild her but leave her still icy and cold.

THREE SONGS FROM WILLIAM TELL

(Es lächelt der See, er ladet zum Bade)

The three songs which come at the beginning of William Tell emphasize the national character of the drama. They present the three types of scenery in which the action is to take place and the three classes of society which will unite in defending the country from oppression. From the songs one can readily assume that it will be a hunter who takes the decisive action against tyranny.

Fisher-boy in a boat:

The lake smiles, inviting, its waters are gleaming; asleep on the shore the fisher is dreaming.

He listens to music, to sounds that entice as singing of angels in paradise.

And when he awakens in longing delight, the waves have surrounded him, holding him tight; a voice from the deep cries:

mine you shall be, enchanting the sleeper I draw him to me.

Shepherd-boy on the mountain slope:

You meadows, goodbye, you bright fields below, the shepherd must go, the summer is past. 
We shall come to the mountains again in the spring, when the cuckoo calls and the song-birds sing, when dressed in her blossoms the earth is gay, when brooks are flowing in lovely May.

You meadows goodbye, you bright fields below, the shepherd must go, the summer is past.

\section{Hunter at the top of a cliff:}

The mountain peaks thunder, the foot-bridges sway, the hunter walks boldly his dizzying way.

He wanders undaunted through ice-fields and snow; no spring blossoms yonder, no trees ever grow.

The ocean below him is misty and white, and hides all the cities of men from his sight; through a rent in the cloud-bank the world is revealed, deep under the waters the flowering field.

Schiller's friend and fellow-Swabian, Friedrich Hölderlin, was born in the little town of Lauffen, on the Neckar River. He attended the University of Tübingen, where he studied theology, not from choice, but because his family was poor, and theological students received free board and tuition. In spite of his antipathy toward his curriculum, Hölderlin's years at the university were of great significance for his later career. Two of his close friends were the future philosophers Schelling and Hegel, and, in company with these mental giants, he read Kant and Rousseau and discovered the glories of Greek literature and culture. After five years at Tübingen, Hölderlin became a private tutor of children as a means of supporting himself until he had established himself as a literary man. His first position brought him to Jena, where he became acquainted with Schiller. The second took him to the home of a Frankfurt banker, Jacob Gontard. The banker's wife, Susette, was a woman of sensitivity, intelligence, and beauty, and the young Hölderlin promptly fell in love with her. Their relations remained Platonic, but after three years Hölderlin's situation became unbearable, and he left. Another position as tutor followed, 
but soon his mind began to fail. His last forty years were spent as a harmless lunatic.

There were three great experiences in Hölderlin's life: the revelation of classic culture, the friendship with Schiller, and the love for Susette. From the study of the Greeks he obtained his ideal of man as potentially a being only a little below the gods, and of beauty as the end of existence. Schiller not only influenced his writings, but fulfilled his dream of the idealistic poet, the prophet of humanity. Susette was the complete embodiment of his vision of classic perfection.

Hölderlin was the third and last of the great German classicists, but unlike the other two, Goethe and Schiller, he received little recognition during his lifetime. Even more than Schiller, he dealt with ideas. Each concrete object, each experience, becomes a symbol, an abstraction. These symbols are often extremely complex, with many implications. The structure of his poems also is often complex. It is based upon what Hölderlin calls the rhythm of ideas and is determined by the rhythmic sequence inherent in the ideas and experiences themselves. The product is seldom free verse. Usually his poems have a dominant metrical foot for which another foot is regularly substituted according to a definite stanzaic pattern. He has a preference for enjambement of lines and stanzas and for inversions and appositions. His language is simple, lyrical, and sensuous, and the prevailing mood is intense and subjective. He seeks oneness for himself and for humanity, a unity of the sensual and the intellectual which can be attained only through love and sacrifice.

\section{HYPERION'S SONG OF DESTINY}

\section{(Ihr wandelt droben im Licht)}

The verses are sung by the hero of Hölderlin's novel, Hyperion. The passively suffering attitude of man in the hands of fate is characteristic of Hölderlin's poems and of their author.

You walk above in the light

on yielding sod, $\mathrm{O}$ blessed genii!

Glistening, god-given breezes

brush you in passing

as harper's fingers

on holy strings.

Fatelessly as the sleeping

infant breathe those of heaven;

chastely kept

in modest buds

their minds and spirits

bloom forever, 


\author{
and blissful eyes \\ are shining in silent \\ endless clarity. \\ But to us is allotted \\ no house nor haven for rest, \\ and, dwindling and falling, \\ we suffering humans \\ plunge ever blindly \\ hour upon hour \\ as water from one \\ lofty crag to another \\ down through the years \\ into uncertainty.
}

\section{(Nur einen Sommer gönnt, ihr Gewaltigen)}

The poem referred to in the second stanza is the drama, Empedocles, on which Hölderlin was working at the time of the composition of this poem. The verses may indicate some awareness on the part of the author of the tragedy which was to end his career.

A single summer grant me, you mighty ones, a single fall to ripen my melodies, so that my heart, by its sweet playing sated, may die then without regretting.

The soul denied its god-ordained right in life not even down below in Orcus shall rest, but, if I gain that thing most holy, lying so close to my heart, my poem,

then welcome, $\mathrm{O}$ repose of the world of shades, for I shall be content, though my string's sweet notes may not escort me downward; I have lived as the gods once and need not sorrow.

\section{OF A MORNING}

\section{(Vom Taue glänzt der Rasen; beweglicher)}

Hölderlin's tendency to etherealize and spiritualize nature is illustrated in the following verses, for what begins as a morning song turns out to be a philosophical treatise on the relationship between mortal man and the eternal powers which control his destiny. Although filled with limitless aspiration, man must bow humbly to his fate. 
With dew the meadow sparkles; more nimbly now the waking streamlet races; the birches bend their supple heads, their leaves are softly rustling and gleaming, and round the sombre

expanse of clouds are ribbons of ruddy flame, the harbingers, they surge forth with silent might as tides against the shore, ascending higher and higher and ever changing.

Come now, O come, but leap not too quickly forth, you golden day, to pinnacles of the sky.

My eyes speed freer, friendlier to you, $\mathrm{O}$ delightful one, when you look down

in morning beauty youthfully and have not yet grown too proud, too glorious far for me; but you might hasten always, could I, heavenly wanderer, go with you, but

you smile with happy arrogance now, that he would be as you. So rather bestow your grace upon my mortal deeds, and gladden, kind one, today this my silent pathway.

\section{EVENING FANTASY}

\section{(Vor seiner Hütte ruhig im Schatten sitzt)}

"Evening Fantasy" reveals the deep sense of loneliness and the indefinite longing of the young and idealistic intellectual who can find no place in a bourgeois society. Only through the sacrifice of dreams and aspirations, concludes the poet, will youth secure peace.

The ploughman sits in shadows before his hut, content; the smoke goes up from his peaceful hearth. The wanderer hears the welcome sounds of evening bells in the silent village.

The sailors too return to the harbor now; the cheerful, busy hum of the market dies in distant towns; in quiet bowers comrades are sitting at festive tables. 
But where shall I go? Mortals exist from work and wages; alternating in toil and rest they all are happy; why sleeps never only in my breast the thorn prick?

A springtime blossoms over the evening sky; unnumbered bloom the roses and calmly glows the golden world; $\mathrm{O}$ call me to you, lavender clouds! For perhaps up yonder

my love and grief will melt in the light and air. But, as dispelled by foolish entreaty, flees enchantment; darkness comes, and lonely under the heavens, as always, I stand.

O come now, gentle slumber, the heart desires too much; but soon your glowing will pale and die, my years of youth, so restless, dreamy!

Then will your autumn be peaceful and cheerful.

HALF OF LIFE

(Mit gelben Birnen hänget)

Hölderlin revelled in youthful emotions, in the pleasure and pain of youthful sensitivity. To lose all this with middle age was a loss for which there was no compensation. The chief appeal which Hellenism had for Hölderlin was its eternal youthfulness.

With yellow pears is hanging and filled with roses the land to the lake; you swans so lovely and drunken with kisses lower your heads in the sacredly sobering water.

Alas, where shall I get my flowers when winter comes, where the sun's warm glow and shadows of earth? The walls will stand speechless and cold, and the weathervanes clash in the wind. 


\section{(Ringsum ruhet die Stadt; still wird die erleuchtete Gasse)}

This poem is the first of a series of eighteen-line odes which deal with the relation of man to the gods. In former times the gods walked upon earth among men and the human soul was exalted by contact with them. Now the gods are asleep, but may come again if men do not lose the dreams and fancies which link them with divinity.

Round us is resting the town; half-lighted streets become silent, and, with torches adorned, carriages rattle away.

Sated with pleasures of day-time, people are wandering homeward, while those with practical heads weigh up their profit and loss well-contented at home; empty of grapes and of flowers slumbers the once-busy market, resting from men and their work. But the soft music of strings sounds from the far-distant gardens; maybe a lover is there, maybe a man who, alone, thinks of his friends and his childhood, longs while the chattering waters, ceaselessly welling and fresh, flow by the sweet-scented blooms. Hushed in the evening air hovers the pealing of churchbells, and the watchman who hears tardily calls out the hour.

Breathing down from the slope breezes ripple the tree-tops; see, now earth's phantom, the moon, stealthily enters the sky and the rapturous night nears with her dreams and her fancies, filled with her stars and indeed little concerned with us men, she, the astonished one, gleams, strange and a stranger among us, sadly and splendidly up over the crest of the hill. 


\title{
VI. THE ROMANTIC POETS
}

\begin{abstract}
Although the immediate effect of the Enlightenment had been to stress the importance of the individual and individual reason, during the course of the century the emphasis began to be placed more and more on man as a link in the chain of historical development, as a cog in the immensely complicated mechanism of a universe controlled by infinite reason. The practical necessity for the individual to subordinate himself to society had been demonstrated by human reason, and literature, at least in the hands of the minor writers, tended more and more toward didacticism, praising such actions as were beneficial to society and condemning those which were detrimental. Aesthetics became lost in utilitarianism. A tree, for example, was beautiful because it fulfilled its logical mission: it gave homes to birds and fuel to man.
\end{abstract}

There was little room in such a weltanschauung of the intellect for the emotions of man, for irrational dreams and indefinite longings. And poets began to feel as restricted and subjugated by reason as they had once been by theological authoritarianism. Storm and Stress rebelled against the rule of cold reason and the subordination of the individual, and the classicists went each their own way, ignoring the prevailing ideology. But neither Storm and Stress nor classicism reflected a general German or European attitude. By the last decade of the eighteenth century, however, the tide of repressed emotions began to break down the barriers of reason, and a new weltanschauung appeared. Beginning in Germany, it spread over western Europe, to England, and to the United States.

If Descartes was the father of the Age of Reason, the German philosopher, Kant, was the progenitor of the Romantic Age. Although he was a child of the Enlightenment, his philosophical system made provision for ideas and concepts which were to a certain extent spontaneous and not the products of sensory perception of environmental factors. With this teaching, the sequence of cause and effect was broken, and the individual was freed from complete subjugation to the physical world. Building upon Kant, the Romantic philosopher, Fichte, established the individual ego as the one provable fact. The non-ego (the physical world) might exist or might be merely a reflection or projection of the ego. The mind of each individual became, therefore, the creator of the universe. The other prominent Romantic philosopher, Schelling, accepted the ego as the creator of the natural world, but taught that it was the equivalent of its product, that is, that ego and non-ego, the mind of man and the natural world, were identical. 
Although relatively few of the artists, musicians, and writers of the Romantic period were familiar with the details of the systems of Kant, Fichte, and Schelling, all were very much aware of the ego as the creative principle and of the close, even pantheistic, relationship between the ego and the natural world. Romanticism became, therefore, an intensely subjective movement, highly individualistic and rebellious against any sort of exterior restraint. The poets gave free rein to their emotions in the attempt to communicate not just ideas, but, in so far as possible, pure feeling. Poetry became very lyrical as the poets attempted to invade the province of music, the art farthest removed from the intellect. The imagination was unleashed from the restrictions of the physical environment, and literature often became so filled with phantasy that it is difficult for the reader to distinguish between dream and reality. Indeed, the poet might have insisted that there was no difference, since both were products of his own ego. Sometimes, however, the emphasis on phantasy took on the aspect of flight. The desire to escape reality was variously expressed in the popularity of the Middle Ages as a setting for literary works, the interest in oriental philosophy and literature, the preference for night and darkness over day and light, the flight into medieval mysticism, and the longing for death.

The favorite structural form among the Romantic poets was that of the folksong. Its loose construction provided both freedom from restraint and unlimited possibilities for the attaining of lyrical and melodious effects.

\section{NOVALIS (1772-1801)}

Friedrich von Hardenberg, who is better known by the pseudonym, Novalis, was born on the family estate near Weissenfels, in Saxony. At the age of eighteen Novalis went to Jena, where he studied history under Schiller and through him became interested in philosophy. At this time he read widely in the works of Kant, and soon afterwards became personally acquainted with Fichte and Schelling. After two semesters at Jena, he transferred to Leipzig, and then to Wittenberg, where he completed his studies in law and natural science.

The one great experience in the short life of Novalis occurred when, at the age of twenty-two, he fell in love with the thirteen-year-old Sophie Kühn. She became the center of his life and his ideal of perfection. When she died, three years later, the shock was almost more than Novalis could bear. This experience both awakened his poetic genius and supplied him with his two main themes: love and death. Love develops in his poetry to a religion akin to primitive Christianity; death becomes the gateway to a reunion with love.

Novalis uses both free verse and short-line, rhymed verse. The latter is usually very simple in structure, with alternating masculine and feminine rhymes. All his language is rhythmical and musical, with indistinct and symbolic overtones. His poetry is an expression of ceaseless longing for the unattainable, the boundless, the infinite. The underlying spirit of his work may be 
called magic idealism. Novalis' chief failing as a poet is that of early Romanticism in general: his emotion diffuses and does not focus on a clear-cut object or situation.

\section{SHALL PASS OVER}

\section{(Hinüber wall' ich)}

The poem is taken from Hymns To The Night, a collection of six hymns in prose and verse, which was inspired by the death of Sophie Kühn. In this work can be traced the sublimation of Novalis' love for his sweetheart into a religious experience. In the early hymns Sophie is the symbol for love; in the later ones Christ is the symbol. This poem marks the transition; the first half of the poem tells of the poet's vision of finding Sophie when he dies, but the "Beloved" of the second half is Christ. The change in theme is emphasized by a change in rhythm.

I shall pass over, each pain I bear will then be pleasure beyond compare.

A few more hours and I shall rest in drunken rapture upon love's breast. Then life unending shall surge in me as, looking downward, I gaze on thee. Upon that hill-side thy gleam shall fade and send a garland of cooling shade. O draw me, Beloved, with power from above, that I may slumber away, and love. I feel now within me death's youth-giving flood, and balsam and ether flow into my blood.

I live through the day-time in faith and desire, and die in the darkness in sacred fire. 
(Muß immer der Morgen wieder kommen)

The symbolism of this poem, which is another of the Hymns To The Night, has night as the symbol for death, and death here below is the womb from which a new life is born. It is the entrance into life eternal. The longing for death, as here depicted, is quite similar to that of the medieval mystics who wished to merge themselves entirely in the Universal Spirit. In the manuscript this hymn appears as prose.

Must morning ever return?

Shall the power of the earthly never end?

And wretched industry consume

the heavenly flight of the night?

Shall never the secret offering of love

eternally burn?

To light was appointed its time

and to waking,

but timeless is the dominion of night,

the duration of sleep is eternal.

Hallowed sleep!

Bestow not too seldom your blessing

on him consecrated to night

in this earthly creation of day.

Only fools do not know you

and know of no sleep

but the shadow

which you in compassion throw over us

in that dusky hint

of the actual night.

They do not feel you

in the golden flood of the grape,

in the almond-tree's

wondrous oil,

and the brown juice of the poppy.

They know not

that it is you

who hovers about the maiden's tender bosom

and who makes her womb heaven.

They do not suspect

that out of old stories

you come, opening heaven,

and carry the key

to the dwellings of the blessed,

of unending secrets

a silent messenger. 
(Der Jüngling bist du, der seit langer Zeit)

A third selection from the Hymns To The Night presents death in the form of a young boy. $\mathrm{He}$ is young because he represents eternal life. It is only through death that humanity is made whole.

That youth are you who now for many years has stood upon our graves in meditation; a hopeful symbol, in our gloom and fears, of dawns of higher human aspiration.

What brought us in the past to bitter tears now draws us all with longing and elation. Eternal life in death has been revealed, and you are death, through you shall we be healed.

MARIA

(Ich sehe dich in tausend Bildern)

The poem is from the collection, Religious Songs, and is one of several which praise the Virgin Mary. In the earlier songs to Mary, she is a symbol of Sophie. Here, however, she is a more universal symbol and represents the divinity in every woman.

A thousand portraits strive to render your face and form with loving art, but none, Maria, is so tender as that I painted in my heart.

The tumults of the world have faded since then, and blown as empty dreams, and heaven's sweetness has pervaded my soul in everlasting streams.

\section{THE HERMIT'S SONG}

(Gern verweil ich noch im Tale)

The longing for death which characterizes the Hymns To The Night is not so pronounced in the subsequent poems. In "The Hermit's Song," from the novel Heinrich von Ofterdingen, we see that through love man can achieve even in this life a mystic and blissful union with the infinite. 
Here I linger still with pleasure, smiling in the deepest night, since love's overflowing measure comes to me with morning's light.

By these holy drops exalted now my soul can boldly soar, in this life, till I have vaulted drunkenly to heaven's door.

I am lulled in blissful seeing till all pain and fears depart. $\mathrm{O}$ ! The queen of every being gives to me her faithful heart.

Bitter years of tears have broken and transformed this clay for me, and engraved thereon a token, granting it eternity.

But those days that know no number seem no longer than a breath; when my life sinks into slumber I'll give thanks for them in death.

\section{CLEMENS BRENTANO (1778-1842)}

Clemens Brentano, the son of a Frankfurt banker, was one of the most controversial literary figures of his day. Handsome, vivacious, and witty, the charm of his personality drew people to him just as his biting sarcasm soon drove them away. He was financially independent and led a roving life, moving from city to city in Germany, Austria, and Bohemia as if some restless demon were always urging him on.

Brentano is best known for the famous anthology of folks-songs, The Boy's Magic Horn, which he and his brother-in-law, Achim von Arnim, compiled. This anthology exerted a strong influence upon German poetry up into the second half of the nineteenth century, and is even today an almost inexhaustible source of folk themes. In addition to his work as an anthologist, Brentano wrote novels, plays, short stories, and songs. His longer works, though marked by luxuriant fancy and deep feeling, betray the faults of the author's character: lack of perseverance and organization. It is as a writer of lyric poetry that he excels. These poems are composed in the manner of folk-songs and are distinguished by a refreshing simplicity of tone and subject. 
Brentano's most productive years, 1803-6, were those of his marriage to the authoress, Sophie Mereau, who exerted the steadying influence that his undisciplined nature needed. After her death his restlessness returned, and his wanderings continued. At the age of thirty-eight he changed from a freethinker to a religious fanatic and found a sort of peace for his troubled soul.

\title{
EVENING SERENADE
}

(Hör', es klagt die Flöte wieder)

Brentano had considerable musical talent, and it may have been because of it that he was so entranced by the sounds of nature. This is one of several evening serenades which he composed in the attempt to capture the music of nature.

\author{
Hear the flute's bewailing sound, \\ see the noisy fountains glisten, \\ golden notes are all around, \\ silence, silence, let us listen! \\ Gentle pleading, tender longing, \\ how it sweetly speaks to me! \\ Through night's shadows, darkly thronging, \\ gleams the light of melody.
}

\section{LULLABY}

(Singet leise, leise, leise)

Brentano's adaptation of the sounds of words to his theme is illustrated by the predominance of sibilant, nasal, and liquid sounds in this whispered lullaby.

Softly, softly, softly croon, sing a whispered lullaby, learn the music from the moon moving still across the sky.

Sing a melody as tender as the brook along the stones, as the bees around the lindenhumming, murmured, whispered tones. 


\title{
(Dein Lied erklang! Ich habe es gehört)
}

The Romantic conception of nature as having a soul which could respond to that of man is illustrated in the poem. In it the birds and the moon and the stars all react with the poet to the song he hears.

\author{
fly through roses to the moon; \\ a butterfly of spring, too soon \\ to a drudging bee converted. \\ Enchanted by your song, \\ for roses now I long.
}

Your song! With joyful heart I heard it

Your song! And now the nightingales begin to sing my lullaby; the moon that listens in the sky, the stars and roses hear my wails. Where does she stay so long, for whom I sing this song?

Your song! No sound in vain would seem, for all of spring which loving urged was deeply in your song submerged; and in my life's dark, longing stream, and in the sunset's gold above I heard your song of love.

THE FOREST

\section{(O kühler Wald)}

The forest plays a prominent role in Romantic symbolism, partly because of the complexity of the emotion which it arouses. It not only represents natural beauty on a large scale, but also the dark, mysterious, and enchanting aspects of nature, with its pre-Christian kobolds, witches, and other forest spirits. The metaphor of the forest in the heart has additional connotations in that it is to some extent a poetic expression of the Fichtean concept of the non-ego as a mirror of the ego.

\author{
$O$ forest fair \\ where do you sigh, \\ in which my darling plays? \\ O echo rare, \\ where do you lie, \\ that listens to my lays?
}




\author{
O echo, stay \\ and sing to her \\ the dreams which I have strewn. \\ My every lay \\ $\mathrm{O}$ bring to her, \\ whom I have lost so soon. \\ My heart is where \\ the forest weeps \\ in which my darling plays. \\ And, troubled, there \\ the echo sleeps, \\ and scattered are my lays. \\ So lonely are \\ the forest ways; \\ O love, come wander too. \\ Though scattered far \\ my many lays, \\ I've more to sing to you.
}

EVENING SONG

(Wie so leis die Blätter wehn)

In most evening songs there is an implied comparison of the evening with death. The Romanticists expanded this comparison to include the connotation of a return to mother nature, of a merging of individual phenomena in the unity of the all. The symbol of the bee entering the flower, which then encloses it, illustrates the concept of a return to the womb from which life sprang. Two stanzas are omitted.

Leaflets tremble overhead in the lovely, silent glade, and the sun now goes to bed; golden garments she has laid on the sod where, all unheeding, supple forest deer are feeding in the glow of evening red.

In the water of the brook now the fish have ceased their play; each one seeks his favorite nook, there to rest and hide away, and in sleep still hears the rushing of the current, leaping, gushing through the pebbles, cool and gay. 
High upon the rocky wall

hangs a slender daffodil,

listening to the humming call

of a tardy bee who will

from afar request a lodging;

through the silken portal dodging,

now it enters, and is still.

\section{LUD WIG UHLAND (1787-1862)}

It was doubtless significant for his future as a professor and eminent medievalist that Ludwig Uhland was born in the Swabian university town of Tübingen, not far from the ancestral castles of the Hohenstauffens and Hohenzollerns, and surrounded by much that recalled the colorful times of the minnesingers. This milieu was certainly important for his verse, for the German Middle Ages furnished Uhland with the best of his subject matter. His interest in the culture and literature of this period was aroused while he was a student at Tübingen and was eventually productive of many volumes of scholarly works and some of the best ballads in the German language.

Uhland's character contrasts sharply with that of Brentano. The Swabian was quiet and almost taciturn where Brentano was witty and voluble. He was practical and confident where the latter was visionary and unstable. And in middle age he gave up the quiet and security of a professorship for a stormy political career not long after Brentano had fled from the world into mysticism. In his threefold position as poet, scholar, and patriot, Uhland perhaps more than any other fulfilled the German ideal.

The chief themes of Uhland's verse are nature, love, folk-sagas, and historical figures and events. He was particularly successful with the ballad, which in his hands approaches a classic perfection of form and style. He divests his medieval knights and ladies of individual traits and presents them as types possessing all the noble virtues. His tone is measured and reflective. Perhaps Uhland's outstanding talent as a poet consisted in his ability to harmonize content and form, to match the subject with the appropriate meter and language. His chief models were the folk-song and the minnesong.

THE CHAPEL

\section{(Droben stehet die Kapelle)}

This is the eleventh-century Wurmlinger Chapel near Tübingen. It is approached by walking along the wooded ridge of the Stiftsberg and is not seen until one steps out of the forest. Then one can look up at the somewhat higher Ammerberg with the chapel at its crest and look down on the pastures, villages, and Neckar and Ammer Valleys which surround it. 
Yonder chapel on the mountain gazes down on life and joy:

in the meadow by the fountain

gayly sings the shepherd boy.

Solemnly the bell is ringing, mournful is the requiem, silenced is the shepherd's singing as he pauses, hearing them.

He whom now they grieve and bury down below was happy, too; some day, shepherd boy so merry, they'll be singing there for you.

\section{SPRING FAITH}

(Die linden Lüfte sind erwacht)

Spring comes early and quickly in the upper reaches of the Neckar Valley and, since the forests are deciduous, the change of seasons is more spectacular than in other scenic areas of Germany. The hillside meadows and the woods are filled with wild flowers.

The winds again are mild and light;

they whisper and wander day and night, through field and forest wending. $O$ fresh perfume, $O$ youthful sound, now, wretched heart, be thou unbound! For now must all the world be mending.

The earth grows lovlier day by day; what yet may be, no one can say: the blossoming seems unending. The farthest, deepest valley flowers; now, heart, forget the painful hours, for now must all the world be mending.

\section{THE INNKEEPER'S DAUGHTER}

(Es zogen drei Bursche wohl über den Rhein)

With the use of rhymed couplets, a tetrameter with varying metrical feet, and dialogue Uhland achieves an authentic folk flavor for his ballad. The poem is particularly effective in its concentration, for in the few lines is indicated the whole story of the previous relations between the dead girl and each of the students. 
There wandered three students once over the Rhine and stopped when they came to an innkeeper's sign.

"Dame hostess, hast thou good beer and wine? And where is that beautiful daughter of thine?"

"My beer and wine is fresh and clear.

My daughter now lies on a funeral bier."

And when they entered in deep dismay, they saw where she in her casket lay.

The first one lifted the veil of lace and sadly looked at the lovely face:

"O wert thou still living, thou pretty one, O then I would love thee from this time on."

The second replaced the veil on her head and, turning away, he wept and said:

"Alas, must thou lie on a funeral bier! My child, I have loved thee for many a year."

The third one lifted once more the veil and placed a kiss on the lips so pale:

"I've loved thee always, I love only thee, I'll love thee through all eternity."

THE SMITH

(Ich hör' meinen Schatz)

Uhland had a keen perception for nuances of feeling and sometimes depicted them admirably. Here, against the rural background of the noisy and smoky blacksmith's shop he sketches the boastful pride of the smith and the love and naive self-assurance of the narrator.

My sweetheart is there;

his hammer is swinging, the roaring and ringing, the echoes and swells resound as of bells through alleys and square. 
My lover sits where

the furnace is nigh him, and when I walk by him the bellows will blow, the embers will glow and flames fill the air.

THE WALK TO THE SWEETHEART

(O brich nicht, Steg! du zitterst sehr)

There is sometimes a touch of good-hearted humor in Uhland's verse, as in this sympathetic portrayal of the urgency of the lover going to meet his sweetheart.

O bridge, don't break, you tremble so!

O cliff, don't plunge to rocks below!

World, don't go under, heaven don't burst,

for I must get to my sweetheart first.

THE CASTLE BY THE SEA

(Hast du das Schloß gesehen)

The contrast between the glories of the past and the remnants of medieval splendor which Uhland saw about him is symbolized in this well-known ballad. The questioner visualizes the castle in the glowing sunlight, with music and dancing, and a king and queen walking in the park beside it. The answerer knows it only by moonlight. He hears a dirge and sees an old couple - certainly not the king and queen - in mourning clothes.

"Have you seen the castle olden, the castle by the sea?

The clouds drift, red and golden above it gloriously.

Its towers at times seem bending from the crag to the waves below; at times they rise, ascending in the evening's crimson glow."

"Well have I seen it gleaming, that castle by the deep, and the moon above it beaming, and the mists that round it creep." 
"Were winds and billows bringing you sounds from the castle walls of dancing and festive singing in the lofty, marble halls?"

"The winds and the waves were sleeping, no music met my ears, but a dirge, and a sound of weeping that moved my heart to tears."

"Were the king and his consort going for strolls on the castle downs? Did you see their mantles blowing and the gleam of their golden crowns?

And with them was their daughter, a maiden, tall and fair?

Bright as the sun on the water with glowing, golden hair?"

"I saw but two old people, in mourning robes arrayed, beneath the chapel steepleI did not see the maid."

Baron Joseph von Eichendorff was born near Ratibor, in Silesia. He studied law at the Universities of Halle and Heidelberg, resided for a time in Paris and Vienna, and in 1813 joined the Prussian army to take part in the War of Liberation. After the final defeat of Napoleon he served as a Government Counsellor successively at Breslau, Danzig, Königsberg, and Berlin. In 1844 he retired from government service and resided in turn at Danzig, Vienna, Dresden, and Berlin.

Although Eichendorff led an active life and travelled widely, neither his fancy nor his verse ever strayed far from the ancestral castle of Lubowitz where he was born and spent his youth. The forested lands around the castle, the valleys and hills, the legends and fairy tales of the surrounding country never lost their childhood enchantment for the poet. It was the magic land from which his inspiration sprang. Lyrical Romanticism reached its peak in Eichendorff's verse. He used the simple form and naive language of the folksong to compose poems of little originality, but of enduring beauty. The world 
of his poetry is one of ancient castles, folk dances in the grove, picturesque mill-wheels turning in the valley, careless wandering, lightly melancholy longing, and dreamy lyric charm. Although Eichendorff's prose works are, with one exception, no longer read, his songs are as popular today as they were a century ago. As long as Germans gather for informal singing, Eichendorff will not be forgotten.

\section{LONGING}

(Es schienen so golden die Sterne)

The essence of German Romanticism is best expressed in the word "longing." Sometimes it was a longing for the medieval past, sometimes a mystic longing for complete union with nature, often it was a longing for death; in many cases the longing was diffused and indefinite with no particular object. The longing of Eichendorff was usually for exotic lands and faraway places.

The stars are so golden and gleaming, as here by the window I stand and hear from the distant hills streaming the sound of a horn through the land. My heart burns with longing to wander, I listen with secret delight $O$ could I but ride with them yonder in the glorious summer night.

I see there two journeymen springing with joy as they wander along, and hear them as, boistrously singing, they banish the silence with song: of dizzying summits of mountains, where the tree-tops rustle so light, of cliffs and of crags where fountains plunge down through the forest night,

of statues in darkening bowers where gardens from hillsides were hewn, of wild-grown hedges and flowers, of palaces lit by the moon, of windows where fair maidens listen as songs of their lovers invite, and waters that murmur and glisten and dance in the summer night. 


\section{(In einem kühlen Grunde)}

Eichendorff found the motif for his song in the poem, "The Miller's Departure," in Brentano's folk song collection, The Boy's Magic Horn. According to the legend, an engagement ring will break if the one who gave it is unfaithful. The mill wheel in the last stanza has become a symbol for the singer's sorrow and the "it" of the last line refers both to the mill wheel and to the longing of the singer for peace.

Beside the shaded water
an ancient mill wheel turns,
but now the miller's daughter
has left those rocks and ferns.

She gave a ring, a token of pledges to be true; her promises were broken, my ring then broke in two.

I would as minstrel wander the wide world up and down, and sing my songs out yonder from town to distant town!

I would with gallant squires ride to the bloody fight, and sleep by silent fires upon the field at night!

I hear the mill wheel turning and know not what I will. For death I'm ever longing, for then it would be still.

\section{A MOONLIT NIGHT}

(Es war, als hätt' der Himmel)

The basic concept of the poem is that the soul is freed by the perfect rapport between the earthly and the heavenly. Eichendorff probably received his inspiration from a passage from the Effusions Of An Art-Loving Friar, by the Romantic poet Wackenroder: "Then it seemed to him as if the great wings of his soul would stretch out... and he would fly up to the bright heavens." 
It was as if the heaven the earth had gently kissed, and she, a shimmer of blossoms, now slept and dreamed of this.

\begin{abstract}
Above her went the breezes, the wheat fields waved delight, the forest whispered softly, so brilliant was the night.

And then my soul, extending its wings, set forth to roam, through silent landscapes wending, as if it flew toward home.
\end{abstract}

\title{
THE EVENING
}

\section{(Schweigt der Menschen laute Lust)}

The song is one of many contained in the novelette, Memoirs Of A Good-For-Nothing, a completely unrealistic tale of the adventures of a simple, light-hearted miller's boy, who wanders and sings his way without a care through a rose-tinted world of perpetual spring, moonlit nights, and romantic castles.

\author{
Sounds of merriment and jest \\ now are stilled, and earth in slumber \\ murmurs- forests without number \\ chorus what the heart has guessed: \\ wondrous legends, wild and frightening, \\ ancient fears as summer lightning \\ flash unceasing through the breast.
}

\section{A CONVERSATION IN THE FOREST}

(Es ist schon spät, es wird schon kalt)

The poem is based on Brentano's ballad, "The Lore Lay," which also provided the inspiration for Heine's "Lorelei." The heroine of Eichendorff's version has become a witch as a result of being abandoned by an unfaithful lover. Any man who looks on her face is bewitched and never finds his way out of the forest. The "errant horns" are those of her victims, who are trying to attract someone to their rescue. 
"The hour is late, the frost is white, Why do you ride through the forest night?

The wood is long, you may not roam alone, fair maid, I'll lead you home."

"O why must men deceive and feign and break a maiden's heart with pain! But heed the errant forest horns and flee. You know her not who warns."

"So richly is the steed arrayed, so lovely is the shapely maid, I know you now. O God, stand by! It is the witch, the Lorelei."

"You know me well. That rock of mine and castle rise above the Rhine.

The hour is late, the frost is white, you'll never leave this forest night."

THE HERMIT

(Komm, Trost der Welt, du stille Nacht)

Eichendorff was deeply religious and in many of his songs there is a strain of the mysticism which is so pronounced in the works of Novalis. The night of the first stanza of the poem becomes death in the last stanza, a death which is followed by the eternal morning of the resurrection. The loneliness reflected in the poem is a genuine expression of the author's life. He was a Catholic living in a Protestant state, a medieval knight born into a bourgeois century, and a literary Romanticist in an increasingly realistic age.

You come, my solace, silent night, so softly from the mountain height; the breezes all are sleeping. A sailor, weary from the day, sings o'er the sea an evening lay of praises for God's keeping.

As clouds, the years have swiftly blown and left me standing here alone; the world goes on without me. You came and all your wonders brought, while I was listening, lost in thought, to rustling woods about me. 
O solace of the world, the night!

The day has wearied me with light;

The darkening sea is dreaming.

I, too, would flee desire and dread

until eternal morning red

through silent trees comes streaming. 


\section{THE POST-ROMANTIC GENERATION}

The period in which the Post-Romantic generation began to write was a period of transition, a time when the dissolution of the old was apparent and the creative forces of the new were not yet visible. The dynamic idealism which had characterized the writings of the Classicists and Romanticists had lost much of its force and conviction by the eighteen-twenties. For the confidence in the creative power of the unfettered individual spirit and the feeling of the essential unity of God, man, and nature had both been undermined by the increasing materialism of an age which stressed society rather than the individual, which questioned the value of metaphysical speculation of any kind, and which was beginning to take a sceptical attitude even toward religion.

It was a period of general disillusionment among the intelligentsia of Germany. The surge of optimism which had marked the final overthrow of Napoleon had been disappointed by the reactionary politics of the German princes under the leadership of Metternich. The beginnings of the industrial revolution cast their shadows ahead and indicated that men would lose not only the individual identity which they possessed under the guild system, but their economic independence as well. Literature and art seemed to have little place in such a materialistc culture and the poets no longer felt themselves to be leaders and prophets, but merely spectators of a scene which they did not understand and of which they did not feel a part. Just as the Metternich reaction looked backwards to an outmoded political theory, the divine right of kings, so the poets looked back to an outworn faith, that of Classicism and Romanticism. But the optimism and mystical yearning of the previous age became ennui and Byronic weltschmerz in their verse. It reveals the struggle to maintain individuality, to remain subject, instead of becoming merely object, to find a real meaning for existence.

Although the folk song had exerted the strongest influence on the form of Romantic poetry, there had also been a great deal of experimentation among the Romanticists in their search for new mediums and techniques for poetic expression. As a result their successors inherited an abundance of adequate and varied vehicles for their thoughts. However, though composition was thus made easy for the heirs, it was often no longer poetic creation in the sense of giving unique form to a particular subject or mood. It was often a technical process of selecting from material at hand the proper meter, stanza, word, or expression. And, as is generally the case when technique is easily mastered, the 
tendency was to make a display of skill in virtuosity. One of the writers of the Post-Romantic generation, Karl Immermann, sums up the literary situation in the novel, The Decadents. "We are decadents," he writes, "and bear the load which falls to legatees. The great agitation in the realm of the spirit, in which our fathers took part,... has brought us a multitude of treasures, which are now available on every counter. Even the slightly talented are able to acquire without special exertion at least the small coin of every art and science.... For the giddiest pretence, for the hollowest opinions, for the emptiest heart is readily found everywhere the most gifted, most powerful expression." Immermann's condemnation was to some extent justified. The verse of his "decadents" characteristically reveals a lack of originality and directness and often seems a product of selective judgment and knowledge rather than of experience. It frequently voices poetic conceptions rather than poetic intuition.

What the Post-Romantic generation lacked above all was a positive weltanschauung and a feeling of kinship with its age. In spite of this lack, however, the best of their number must be counted among the outstanding poets of Germany. They were not only virtuosos of style, but also consummate artists who were in complete command of their material. Their very rootlessness and aloofness from society gives their verse a modernness which anticipates such twentieth-century poets as Rilke and George. And in the works of at least one, Mörike, can be found all of the elemental fervor of Romanticism coupled with an artistry which none of the Romanticists had equalled.

\section{FRIEDRICH R ÜCKERT (1788-1866)}

Friedrich Rückert was born in the city of Schweinfurt and grew up in a nearby village where his father was magistrate. He studied law at Würzburg, languages and literature at Heidelberg, and oriental languages at Vienna. He became Professor of Oriental languages, first at Erlangen, then at Berlin. During his early manhood he took an active interest in the political situation in Europe and composed many patriotic songs. But after the defeat of Napoleon he lost interest in the contemporary scene and retired more and more to his studies. His long life was quiet and peaceful, undisturbed either by great joys or great sorrows.

Rückert was one of the many outstanding German scholars who were also literary men. He produced a large number of scholarly writings, translated major works from Sanscrit, Hebrew, Chinese, Persian, Arabic, Armenian, and Greek, and read widely in almost every written language. He became the most important interpreter of Oriental poetry in Germany and, as such, exerted a strong influence upon German literature. Rückert's own verse is distinguished by great virtuosity of form and language. It is not organic growth out of his own imagination and experience, but rather the result of a meticulous selection of thoughts and expressions from his immense fund of knowledge. His poetry was influenced particularly by Persian literature, but there are few verse forms in any literature which he did not at some time employ. 
(Der alte Barbarossa)

This poem is one of Rückert's earlier works and is fully in the Romantic tradition. The legend on which it is based is as follows. When the Hohenstauffen emperor, Friedrich I, drowned in a river on his return from a crusade, the Germans refused to believe the report of his death. The story spread that he was sleeping in a mountain cave and would one day awake, save Germany from its enemies, and unite its various states into a great empire. Rückert wrote the poem at about the time of the War of Liberation against Napoleon.

Old Friedrich Barbarossa, the emperor renowned, inhabits now, enchanted, a castle underground.

Not dead is he, but resting, he still lives there today, and in this hidden castle he sits and sleeps away.

He took the empire's glory down with him in its prime, and will return in splendor with it, in his own time.

The chair on which he slumbers of ivory is made, the table is of marble on which his head is laid.

His flowing beard, not flaxen, but red with fiery glow, has grown right through the table and to the stone below.

He nods and stirs in dreaming and winks a sleepy eye, and now and then he beckons a servant, standing by.

He speaks to him in slumber: "Find out, $\mathrm{O}$ dwarf, if still you see the ravens flying above the castle hill. 
And if the ancient ravens

above the castle soar,

then I must sleep, enchanted,

a hundred years or more."

\section{O STOP WITH ME}

\section{(Du bist die Ruh')}

The poem is contained in the collection, Oriental Roses, which was one of the first products of Rückert's study of Persian. In the collection of verse Rückert assumes the personality of the Persian poet, Hafis, a cynic and Epicurean who sings the glories of wine and love. The Oriental tone is well preserved and some of the poems are actually re-workings of particular songs by Hafis. "O Stop With Me" is not so much directed to a specific woman as it is a longing for perfect love.

Thou art repose and quiet calm, desire that glows and cooling balm.

I give thee, dear, with joy and sighs a dwelling heremy heart and eyes.

Stop in with me and be not late, and after thee make fast the gate.

Have care depart from out this breast, and fill my heart with love, and rest.

Alone through thee my eyes have sight; $O$ let them be filled with thy light. 
(Du meine Seele, du mein Herz)

This is one of a collection of poems called Love's Spring, which contains Rückert's best love songs. They were inspired by his passion for Anna Luise Wiethaus-Fischer, whom he married in the same year, 1821, as that in which the poems were written. Rückert's longing for love was completely satisfied in this happy marriage, and these were the last true love songs which he wrote.

\author{
O thou my soul, $\mathrm{O}$ thou my heart, \\ thou my delight, my pain thou art, \\ the world art thou, which I discover, \\ my heaven thou, in which I hover, \\ $\mathrm{O}$ thou my grave, the open tomb \\ in which I bury grief and gloom! \\ My rest and my tranquility \\ art thou, that heaven granted me. \\ That thou shouldst love me, makes me greater, \\ thy glance has been my new creator, \\ thou raisest me with love on high, \\ my guiding light, my better I.
}

\title{
GHASEL
}

(Pan, der Hirte, spielet seine)

The ghasel is an Oriental verse form, the distinguishing characteristic of which is the single recurring rhyme. Rückert introduced it into German literature and composed many of them, some over twenty lines in length.

When Pan, the shepherd, plays divine, melodic notes at evenshine, the many sounds of nature melt and to one song and voice combine. Then through the seven pipes respire the seven heavens at his sign.

The shepherd, Pan, now plays and sighs and slumber walks through tree and vine. Within her stone sleeps Oreas and Dryas nods within her pine. Endymion, for evermore a sleeper, sleeps at Luna's shrine. The shepherd, Pan, is playing-drunk is all the world on slumber wine. 
Count August von Platen-Hallermünde was born in the city of Ansbach, in Bavaria. At the age of eighteen he became an officer in the Bavarian army and took part in the war against Napoleon. After the cessation of hostilities he attended the University of Erlangen, where he became acquainted with Rückert and Schelling. From the scholar he learned Persian and was inspired to adapt Oriental forms to German verse. From the philosopher came the view of nature as a world spirit seeking union with man. Like Rückert, Platen knew many languages and could draw themes and metrical forms from an exceptionally broad literary background.

To his contemporaries Platen was a cool, aristocratic, unapproachable nobleman, the author of haughty satire and cold, finely polished verse. The diaries, which were published years after his death, reveal him as a weak, unstable, tormented man, who concealed himself behind an austere exterior. They record wild outbreaks of longing, weeping lamentations, passionate despair. Throughout his life Platen suffered keenly in the struggle between his strict sense of morality and his unconquerable homosexual tendencies. And it was this inner struggle that isolated him from society and dictated the formality of his manner and verse. The strict form of his odes and sonnets resulted both from conscious discipline and from the obvious impossiblity of unreservedly baring his soul in his poetry. The content of Platen's poems, therefore, does not arise from his experience, but from literary tradition. In his works there is nearly a complete separation of life and art. Now and then, however, selfrevelation gleams through his virtuosity and impersonal reserve. Then a language of sweet, almost sinister euphony reveals nameless sorrow in its beauty. Platen, as perhaps no other poet, experienced beauty as the mask of death. Where Rückert's verse belongs, in general, to the Romantic tradition, Platen's poetry has little of Romanticism in it and reveals an affinity to that of the German Classicists.

Although many of the poets, including Goethe, appreciated Platen's talent, the general public ignored his writings. Disappointed and embittered, he fled to Italy where he spent the last years of his life.

THE PILGRIM BEFORE ST. JUST

(Nacht ist's, und Stürme sausen für und für)

The pilgrim who is standing before the monastery of St. Just is Charles V, who has just abdicated as King of Spain and Emperor of Germany. The emphasis on decay is characteristic of Platen's verse.

Night falls and storm winds roar unceasingly;

O Spanish monks, unlock the gate for me. 
And let me sleep a while upon a chair until the chapel bell drives you to prayer.

Prepare for me the little that I crave: a habit of your order and a grave.

Make me as one of you, a cell assign; once, more than half of this great world was mine.

The bended head which now of locks is shorn a host of diadems and crowns has borne.

The shoulders which now stoop a cowl to don have often had imperial ermine on.

Now I, before my death, am as the dead, hang, like the ancient empire, by a thread.

THE GRAVE IN THE BUSENTO

(Nächtlich am Busento lispeln bei Cosenza dumpfe Lieder)

According to the historian, Gibbon, the Visigoth king, Alaric, was buried by his followers in the bed of the Busento River. The long, divided lines, rhyming in couplets, which Platen uses here, are characteristic of the German heroic epic; so, too, is the use of alliteration.

Night and near Cosenza softly murmur sounds of muffled singing, and Busento's waters answer with the eddies' whispered ringing.

Up and down the river wander shadows of the Goths, departed, who for Alaric are weeping, bravest of the lion-hearted.

Far from home and all too early they interned beneath the boulders him whose youthful locks, still golden, hung in curls about his shoulders.

By the banks of the Busento brother labored by his brother; for, to change the river's channel, they were digging it another.

In the empty bed they burrowed, dug the chamber ever larger into which they sank his body, dressed in armor, on his charger;

covered up his proud possessions with the earth: his sword, cuirasses, so that on the grave might flourish once again the river grasses. 
Then the water was diverted to its ancient bed and willows: raging through the rocky chasm rushed again Busento's billows.

"Sleep in all your hero's honor!" sounded now the warrior chorus, "safe from Roman greed forever is the foaming tomb before us."

And throughout the host resounded songs of praises and devotion; carry them, Busento's waters, from Cosenza to the ocean.

\section{REMORSE}

(Wie rafft' ich mich auf in der Nacht, in der Nacht)

This poem was written while Platen was a student of Schelling's at the University of Erlangen. The poet is attempting to quiet his remorse by establishing the close harmony with nature that is basic to Schelling's philosophy. Platen's use of anapests emphasizes with exceptional facility the movement and change which the poet sees about him.

I sprang from my bed in the night, in the night, and, drawn by a mystical power, the streets with their watchmen were lost to the sight, as I passed in my flight in the night, in the night, through the gate with the old Gothic tower.

The millstream raced from its source on the height; I looked from the footbridge with yearning, and saw far below me the splashes of white; they glided so light in the night, in the night, departing and never returning.

Above in the firmament, countless, and bright, moved stars in the wheel of existence, and with them the moon shone in quiet delight; they sparkled so light in the night, in the night, through deceptive and measureless distance.

Above and below in the night, in the night, I saw change and movement continue: alas, you have wasted the days in their flight; now silence the blight, in the night, in the night, and remorse that is burning within you. 
(Wer die Schönheit angeschaut mit Augen)

In the work of Platen there is a strong awareness that the artist is doomed by the very nature of his being to separation and isolation from his fellow men. He is no more a spokesman and prophet for the people, but one whose poetic gift is a curse which condemns him to solitary self-torment.

Who once has looked on beauty with his eyes

is then already given unto death, for earth will offer neither wage nor prize, yet he will fear to lose his life and breath, who once has looked on beauty with his eyes.

Eternal are for him love's pain and fire, for only fools can hope on earth to quit or satisfy such limitless desire;

who by the dart of beauty once is hit, eternal are for him love's pain and fire.

O he would want to end a stagnant well, to suck in poison from the earth and skies, and death from blooms and blossoms with each smell; who once has looked on beauty with his eyes, $O$ he would want to end a stagnant well.

Heinrich Heine was born in the Rhineland city of Düsseldorf. After several unsuccessful attempts to establish himself in business, he studied at the Universities of Bonn, Göttingen, and Berlin, and received his doctor's degree in 1825 . After trips to London and Italy, and a short period as a journalist, Heine left for Paris, where he spent the rest of his life. During his last years he was in poor health and finally suffered almost complete paralysis.

Since Heine wrote mainly prose during his later years, his reputation as a poet rests chiefly upon the productions of his youth, the period which began with the sentimental and highly imitative verse of the collection, "Young Sorrows," and ended with the powerful, surging rhythms of the "North Sea" cycles. With his pronounced lyrical qualities and his astute critical judgment, Heine was exceptionally well equipped to exploit the treasures which the "Golden Age of German Literature" had bequeathed him. His verse is polished and extremely melodious. It is subjective and reflects a complicated, unstable personality, a personality that in rapid succession reveals sensualism and Epicureanism, 
renunciation and Titanism, pathetic self-pity and hard, ironic disillusionment. How much of Heine's emotion was real and how much was assumed cannot be determined, but it is certain that the poet was always an actor, playing roles which he changed frequently and capriciously.

\section{BELSHAZZAR}

\section{(Die Mitternacht zog näher schon)}

The significance of the handwriting on the wall is much greater in Heine's poem than in the account in the Book of Daniel. In the Bible the handwriting serves only the purpose of prophesy; in Heine's version it is the direct cause of Belshazzar's death, in that it incited the terror-stricken courtiers to murder. The immediate inspiration for the poem came from a translation of Byron's "Vision of Belshazzar."

The sun had set and day was done;

in silent rest lay Babylon.

But in the castle of the king

were lights and boisterous reveling.

Up there within the banquet hall

Belshazzar held a feast for all.

His retinue sat in glittering lines and emptied the goblets of sparkling wines.

The goblets jingled, a song went round; the headstrong monarch was pleased by the sound.

His cheeks burned red and his heart grew cold; the flush of wine made the monarch bold.

By the drink and revelry blindly stirred, he blasphemes God with a sinful word.

He boasts and curses long and loud to the roaring applause of the drunken crowd.

The king commanded, his face was stern; the servant vanished to soon return, carrying vessels of gold. He bore Jehovah's temple's priceless store. 
The monarch seized a sacred cup with wanton hand, and filled it up.

He emptied the cup in a single draft, and then with foamy lips he laughed.

"Jehovah, your glory and power is gone;

I am the king of Babylon."

He hardly had uttered those words of scorn, when his heart with terrible fear was torn.

The rowdy laughter ceased, instead, on the banquet hall lay silent dread.

But look! But look! Before them all a hand appeared upon the wall.

And wrote, and wrote upon the wall with fire- and vanished from the hall.

The monarch stared with halted breath, with trembling knees, and pale as death.

The courtiers sat with horror filled; the festive banquet hall was stilled.

The wise men came at the monarch's call, but none read the message upon the wall.

That night his courtiers fell upon, and killed Belshazzar of Babylon.

\section{Poems From LyRICAL INTERMEZzo}

The collection of poems entitled Lyrical Intermezzo was written while Heine was a student at the University of Berlin, at a time when his verse was highly Romantic in nature. In these poems he employs the style and mood of the folk song to express his love for Amalie Heine, his cousin.

\section{In That Exquisite Month Of May (Im wunderschönen Monat Mai) \\ In that exquisite month of May when all the buds were breaking, I felt within my bosom new life and love awaking.}


In that exquisite month of May with all its forest choirs, I spoke to you, confessing my longings and desires.

\section{From Out My Tears Of Sorrow}

(Aus meinen Tränen spriessen)

From out my tears of sorrow a host of blooms will spring, and from my plaintive sighing the nightingales will sing.

If you but love me, dearest, the blooms you shall have without fail, and under your window shall echo the song of the nightingale.

3. O When I Look Into Your Eyes (Wenn ich in deine Augen seh')

O when I look into your eyes, then all my care and sorrow flies; and when I kiss your lips, my pain is gone and I am well again.

When I recline upon your breast, then heaven's joys are manifest; yet when you say: "I love you so!" then bitter tears begin to flow.

\section{The Lotus Flower Is Fearful}

(Die Lotusblume ängstigt)

The lotus flower is fearful beneath the noonday light; with lowered head and spirit she dreamily waits for the night.

The moon is her ardent wooer, she wakes at his fond embrace; to him she is kind, and uncovers her pretty flower face. 
She blooms and plumes and glitters, and silently looks above;

she weeps and sends forth fragrance with love and the pains of love.

\title{
5. A Lonely Pine Is Standing
}

(Ein Fichtenbaum steht einsam)

\author{
A lonely pine is standing \\ in the North on a bare plateau; \\ he drowses under a blanket \\ of sparkling ice and snow.
}

He sleeps and dreams of a palm tree far off in an Eastern land, alone and silently grieving mid burning leagues of sand.

\section{SAT BY THE PALING SEASHORE}

\section{(Am blassen Meeresstrande)}

This is the introductory poem to the collection, The North Sea. With powerful, variable rhythms and in an impressionistic style Heine presents two contrasting pictures: the lonely, noisy, and violent seashore and the quiet and homey entryway.

I sat by the paling seashore, troubled by aimless reflection and lonely. The sun sank lower and lower and cast red-glowing streaks across the water, and the broad and gleaming breakers, pressed by the tide, thundered and foamed as they came ever nearer: a singular sound, a whispering, a whistling, a laughing and murmuring, sighing and sobbing, and with it a comforting lullaby-crooning.

Did I perhaps hear forgotten sagas, ancient and beautiful legends which in boyhood often I heard from the children of neighbors, when there on summer evenings on the flagstone steps by the doorway we huddled to hear the quiet stories 
with little, listening hearts

and wide, inquisitive eyes.

Meanwhile the older maidens

sat near the pots of fragrant flowers

opposite us by the window,

with rosy faces

smiling and moonlit.

Weltschmerz, that pathological mental and emotional condition which was characteristic of dying Romanticism, is particularly evident in the life and works of Nikolaus Niembsch von Strehlenau, whose pseudonym was Nikolaus Lenau. Lenau was born in Hungary of a German father and a Hungarian mother. His father died while he was still young, and he grew up idolized and spoiled by his mother and sisters. His erratic nature can be seen in the vagaries of his education. At various institutions he studied in turn Hungarian law, philosophy, agriculture, again philosophy, Austrian law, and finally medicine. He did not complete the course of study in any of these fields.

An extreme restlessness drove Lenau from Austria to Württemberg, where he became acquainted with the circle of Swabian poets to which Uhland belonged. Here he found an appreciation for his poetry, but not contentment, and soon he left for America. There in the great virgin forests and endless prairies he hoped to find peace for his soul and food for his poetic fantasy. He was, of course, disillusioned, and returned in less than a year to Europe, where his restless demon continued to drive him from place to place. These were years marked by a succession of love affairs which inspired many songs, but did not lead to marriage. In 1844 Lenau suffered a severe nervous disturbance which soon led to insanity.

Lenau is a poet of passion, but his passion is not the creative force of a strong, primitive spirit. It has something of a trembling nature, of intense, neurotic excitement. His verse has a pessimistic and negative character which shows only the ephemeral and transitory aspects of life. He is a poet of nature, but his nature does not have an existence of its own. It is rather a reflection of the poet's darkness and gloom. Of the major poets of the Post-Romantic generation Lenau was technically the least skillful, and even some of his best verse has an occasional rough word or line. Nevertheless, many of his poems have a vitality of imagery and a truth of emotion which give them a permanent position in German literature. 
(Weil' auf mir, du dunkles Auge)

The poem was written for Lotte Gmelin, with whom Lenau fell in love in 1831 while in Stuttgart. Lotte returned his affection, and the lovers spent two happy months almost constantly in each other's company. But Lenau was afraid of this happiness and, instead of asking her to marry him, ran away to Heidelberg. The poem has become a favorite of composers and has over 100 musical settings.

Rest on me, you eye of blackness, let me know your fullest might, solemn, dreamy, kind, caressing, sweet, unfathomable night.

Take from me with dark enchantment all the sunny world of light, that above my life may hover ever only mystic night.

SEDGE SONGS

(Drüben geht die Sonne scheiden)

The "Sedge Songs" were written after the poet had forsaken Lotte. They are an expression of his longing for her and for the happiness they might have had.

1.

Now the sun its task is ending, weary day has gone to sleep, and the willow trees are bending to the pool, so still, so deep.

I have left my love to wander; flow, my tears, in bitter pain. Sadly sighs the willow yonder, and the wind sweeps through the cane.

On my sorrow's fiercest billows distant magic gleams afar, as through rushes here, and willows, softly gleams the evening star. 


\section{2.}

Clouds chase by, the moon is paling, dreary rain falls through the night, and $I$ hear the winds bewailing:

"Pool, where is your starry light?"

And they seek the vanished shimmer deep within the surging sea; so your love shines ever dimmer down into my misery.

3.

Over secret paths and ledges oft I steal when day is through to the barren sea of sedges, maiden, where I think of you.

In the darkened thicket swaying, rushes murmur as in sleep, and lament and whisper, saying: "I should weep, O, I should weep."

And I seem to hear the singing of your voice pass to and fro, to the reeds and rushes clinging, sinking to the pool below.

4.

Where the placid pool reposes peacefully the moonbeams rest, lightly weaving pallid roses in the sedge's greening crest.

On the hill the red-deer grazes, lifts his head to look at me, wild-fowl stir within the mazes of the rushes dreamily.

I must weep as longing surges, for your image, hidden there in my deepest soul, emerges like a silent evening prayer. 


\section{THE THREE}

\section{(Drei Reiter nach verlorner Schlacht)}

The form of the poem, with its short stanzas, laconic dialogue, and sudden transitions, is almost exactly that of "The Innkeeper's Daughter," by Uhland. Indeed, Lenau probably used the latter poem as a model. However, the concluding lines of "The Three," which rob death of beauty, romance, and even dignity, are quite unlike anything by Uhland and illustrate a basic difference not only between the two poets, but also between the Romanticists as a group and the post-Romantic generation.

Three vanquished horsemen from the fight, they ride so softly, ride so light.

From mortal wounds wells forth the blood, the horses feel the warming flood.

It drips from saddle and from rein, and washes dust from boot and mane.

The horses' steps are smooth and slow and gentle, to retard the flow.

All three abreast the riders ride, each leaning on another's side.

They look at pallid hand and cheek, and then in turn the riders speak.

"A lovely maid at home have I, because of her I would not die."

"I've house and farm with forest near, and must I fall and perish here?"

"I've nought but sight to see the wood, yet I would keep it, if I could."

And close upon the ride of death the vultures soar with stinking breath.

With screeches they assign the three:

"That one's for you, this one's for me." 
The desire to escape reality, which led Novalis into mysticism, drove Brentano into religious fanaticism, kept Eichendorff continually wandering in search of the idyllic existence of his youth, and caused even the rugged and practical Uhland to retire frequently into the Middle Ages, was particularly strong in that late-comer to Romanticism, the Swabian Eduard Mörike. "There is an especially painful trait in my personality," he once wrote to a friend, "that makes me fearful and ill at ease when anything new - even the most trivial thing - intrudes upon me from the outside, though only briefly." He preferred to live, cut off from reality, amid the quiet beauty of the world of his fancy. His works describe the landscape, the population, the history, and the mythology of that inner world.

As a result of his passive nature and extreme sensitivity, Mörike's outer life was unhappy. After completing his theological studies at Tübingen, he served as a vicar at several places in Württemberg until, in 1834, he received a pastorate of his own. After nine years poor health forced him to retire on a small pension, from which he obtained a precarious existence for the rest of his life. His fame came late; indeed, it reached its height years after his death.

As a lyric poet Mörike has been ranked second only to Goethe. Although his works are highly subjective, he possesses the skill for the older poet in giving universal significance to individual emotion. Also like Goethe, he expresses his thoughts and emotions through tangible, plastic symbols. Whether he uses rhyme, blank verse, or free verse, Mörike's language is clear, natural, and harmonious. And he has the rare ability to select always the proper form and mood for the presentation of each individual poetic concept.

WEYLA'S SONG

(Du bist Orplid, mein Land)

Weyla was a goddess of the imaginary island of Orplid, which was located in the Pacific Ocean between New Zealand and South America. It was a wonderful, enchanted island which had been invented by Mörike and Ludwig Bauer when they were students at Tübingen. The two friends used to retire to Orplid and its race of heroes whenever Tübingen became too demanding or too dull.

Thou art Orplid, my land

that distant shines;

the oceans, altered by thy sun-lit strand

to mists, refresh the cheeks of the divines.

Primeval seas ascend, reborn, about your hips, my child;

before thy god-head bend

the kings who are thy nurses mild. 
SECLUSION

(Lass, O Welt, O lass mich sein)

At the time the poem was written Mörike had been engaged to a Luise Rau for two years, but saw no prospects of securing a position which would make it possible for them to marry. The mood of these verses was perhaps a reflection of the hopelessness of his position.

Leave me, world, and let me be, lull me not with love's caress, let this heart alone possess its delight and agony.

What I mourn, I cannot saymisty longings, haunting fearsand I only see through tears all the lovely light of day.

Though by unknown pain oppressed, yet do gleams of pleasure thrill through the melancholy chill rapturously within my breast.

Leave me, world, and let me be, lull me not with love's caress, let this heart alone possess its delight and agony.

SOUL, THINK OF THIS

(Ein Tännlein grünet wo)

The song comes at the end of Mörike's delightful short story, "Mozart On The Journey To Prague," and foretells the death of the composer.

A fir tree greens somewhere, who knows the forest, a rose, in who can say which flower garden?

Already are they chosen, soul, remember, to sink their roots and flourish on your casket.

Two sable colts are grazing in the meadow, they canter back to town 
with merry gambols.

But they will gravely walk

with your dead body,

perhaps, perhaps before

upon their hooves

the iron loosens

which I now see gleaming.

\section{SEPTEMBER MORNING}

\section{(Im Nebel ruhet noch die Welt)}

Although Mörike's life was a flight from the realities of society and social institutions, it was not a flight from the reality of nature. In many of his poems Mörike reveals how the beauty of nature sometimes broke through into his soul's seclusion as the rising sun suddenly penetrates the mists in which wood and field are dreaming.

The world still rests in misty white and wood and field are dreaming; the veil is rent - before the sight the azure heavens flood with light and silent earth in autumn might with molten gold is streaming.

\section{MIDNIGHT}

\section{(Gelassen stieg die Nacht ans Land)}

Mörike, like the dreamy, mysterious night, has divorced himself from the brightness of day. But the springs and the brooks cannot forget the light, and even in slumber sing to him of a life in which he no longer shares.

The night, now risen from the sea, leans on the mountains dreamily and gazes on the golden scales of time, which rest in balance, neither fall nor climb; more boldly murmur the brooks in flight, they sing in the ear of their mother, the night, of the day, of the fleeting delights of the day.

That old, primeval slumber song she heeds no more and thinks too long, and sweeter is the sound of heaven's blue, 
the balanced yoke of changing hours, too; but ever the brooks murmur down the hill, the waters are singing in slumber still of the day, of the fleeting delights of the day.

TO AN AEOLEAN HARP

\section{(Angelehnt an die Efeuwand)}

Mörike uses the Aeolean harp as a symbol of the soul which is played upon by the beauties of nature and the sombre forces of its destiny. The boy mentioned in the second stanza was Mörike's brother, August, who died in childhood.

Leaning against the ivy-clad wall of the ancient terrace, you, a breeze-born muse's mysterious string music, begin, begin once more your melodious wailing!

You come, you winds, from far away, $O$, from the boy's (I loved so fondly) freshly greening hill. And, spreading gay, spring blossoms on the way, with pleasant odors surfeited, how sweetly you torment this heart!

And murmur here to the strings as drawn by harmonious sadness, swelling as deepens my longing, and waning again.

But without warning, as the wind blows ever stronger, a lovely cry of the harp repeats to my sweetest alarm my soul's sudden emotion; and here - the full-blown roses, shaken, scatter all their petals at my feet. 


\section{POETS OF REALISM}

At the time when most of the Post-Romantic poets began to write, German culture was in a period of transition. It lacked distinctive features, had no definite system of values, and reflected no specific weltanschauung. Earlier writers had spoken for their times - the poets of the eighteenth century had expressed in their verse the spirit of the Enlightenment, those of the early nineteenth century the spirit of Romanticism - but the generation which immediately followed the Romanticists had found itself without a definite framework, writing for an age that had nothing new to say. The times had no characteristic spirit, and poetry took on the rootlessness of l'art pour l'art. However, by the middle of the century a new weltanschauung was apparent which was to give Germen culture once more a distinctive complexion and not only German culture, but also that of the entire Occident. This was the weltanschauung of Realism.

Realism did not appear as a revolution in thought or as a violent reaction to Romanticism, but was the result of a gradual development from idealism toward materialism, from the subject to the object, from the individual to the group. Revolutionary ideas were advanced in all cultural areas during the middle years of the nineteenth century; and although they were regarded with suspicion by the great majority of Germans, they did determine the direction in which the culture was to move. The philosophy of Ludwig Feuerbach is significant as a sign of the times. Feuerbach renounces any sort of divinity operating in either man or nature. Indeed, he denies the existence of nature in the sense of an organic unit and defines it as merely the sum of its components: light, water, air, plants, etc. There is also no human soul. What is called a soul is only the sum of the mental functions of man. It is a product of the body and is incapable of independent existence. Thought is a chemical process, the product of which is ultimately the result of hereditary and environmental factors. There can, therefore, be no free will. Life is nothing more than the complicated interworking of chemical and physical forces, and the only possible purpose of life is earthly happiness. The sole function of society should be to provide the greatest happiness for the greatest number of people.

This materialistic philosophy received unexpected support from theology when in 1835 David Friedrich Strauss published his widely read Life Of Jesus. Here Jesus is presented not as God, but purely as a man, and his miracles are explained on a rational basis. Feuerbach's theories were supported even more 
strongly by science, particularly by the conclusions of Darwin in his Evolution Of Species. And in the fields of economics and sociology, Feuerbach's materialism was advanced in the various publications of Karl Marx. However, extreme materialism was absorbed slowly and did not dominate German thought until the last decade of the nineteenth century, and then only briefly. In the meantime Realism maintained a middle ground which preserved at least something of the idealism of the Romantic period.

The most immediate effect of philosophical materialism on Realism is seen in a new conception of the poet. The godlike creative genius of Romanticism becomes the bourgeois narrator of the everyday experiences of everyday people. This narrator gives more emphasis to objective description and less to subjective reactions. The problems which he presents do not deal with cosmic relationships, but rather with the relations between individuals, usually quite ordinary individuals. Supernatural and fanciful themes are avoided, as are also violent outbursts of passion. The poetic language of Realism is usually simple, factual, and sentimental rather than highly emotional.

\section{FRIEDRICH HEBBEL (1813-1863)}

There could hardly be a greater contrast to the weakness and indecision characteristic of the Post-Romantic generation than the indomitable courage and strength of Friedrich Hebbel. He was born in Schleswig-Holstein into a poor laborer's family, but by enduring all sorts of privation he managed to get a good education. He studied in Heidelberg, Munich, and Paris before settling down in 1846 in Vienna, where he spent his later life.

Like Schiller, Hebbel is a poet of ideas. Although the inspiration for his verse came from the outer world of phenomena, the finished poem was an expression of the inner world of his thought. The object or incident discussed in the poem became a symbol for an idea or concept. Hebbel's ideology is not based on the materialism associated with Realism, but may be described as intellectual Pantheism. The world spirit, the absolute idea, is the basic fact of existence. It is the all-inclusive factor which splits up into the innumerable units of individual phenomena, including human beings. The universal spirit must separate itself in this way, because life and matter can be achieved only in the particular. However, the universal entity must be preserved, and that is accomplished through death, which calls all things back from individual to universal being. But the individual is at odds with the universal spirit, for it has in it the longing for separate existence and self-determination. This longing is a sin; indeed individual existence is in itself a sin which can be expiated only through death. The main theme of Hebbel's tragedies and of his poetry is the relationship between the individual and the universal, the eternal circle of nature which produces life only to destroy it. His verse is serious, for according to his philosophy life is necessarily tragic. But he illustrates in his works that a tragic outlook is not always a pessimistic one. 
Hebbel is classed with the Realists, in spite of his idealistic philosophy, because of his objectivity and his factual approach to literature. His poetic expression aims at maximum clarity and is almost prosaic. His language is simple and almost completely without poetic adornment, and his depiction of emotion is always regulated to the logic of human reason. A careful selection of melodic words, however, gives a lyric quality to his verse.

\section{REVELATION}

\section{(In unermesslich tiefen Stunden)}

He who has once looked into his own soul has had a glimpse of the universal spirit. From then on his life is free, for he has seen the necessity for death.

In infinitely solemn hours, have you perceived the flaming coal that marks the cosmic spirit's powers sink burning down into your soul?

Each living being to enthrall with wondrous feeling and with rest, he enters in the narrow hall of mortal life as honored guest.

Peer through the darkness of the veils that round the great unknown are furled; a single radiant beam details a glowing picture of the world.

He drinks from universal life, he rides the clouds from pole to pole, and floats above all earthly strife, who once has looked into his soul.

\section{REQUIEM}

(Seele, vergiss sie nicht)

All the particles of universal being long for individual identity. Even after death they have a certain identity as long as they are remembered and loved.

Soul, do not forget them, soul, do not forget the dead! 
See, they hover round you, shuddering, forsaken, and in the holy fires, which love kindles for these poor ones, they relax and warm themselves and enjoy for the last time the dying embers of their lives.

Soul, do not forget them, soul, do not forget the dead!

See, they hover round you, shuddering, forsaken, and when you coldly turn from them, they freeze down to their deepest being. Then they are seized by the storm of the night, which they, when contracted into themselves and safe on the bosom of love, once defied; and it chases them furiously through the endless wastelands, where there is no more life, only struggle of released forces

for renewed being.

Soul, do not forget them, soul, do not forget the dead.

\section{A PICTURE OF SUMMER}

(Ich sah des Sommers letzte Rose stehn)

Much of Hebbel's poetry turns on minor but dramatic incidents. The dividing line between individual and universal existence is so fine that even the wind from a butterfly's wing can effect the transformation.

Of summer's roses this one was the last it seemed to drip with blood, it was so red; I spoke with trembling voice as I walked past: so far in life is too near to the dead!

No breath of wind stirred in the sultry day, a lazy butterfly flew near. The air was gently moved, and as it soared away, the petals shook and fell; the rose was bare. 


\section{A PICTURE OF FALL}

(Dies ist ein Herbsttag, wie ich keinen sah)

Here merely the rays of the sun are sufficient to bring the apples back to the universal spirit so that the cycle of life, death, and rebirth may go on.

I've never seen an autumn day so clear and air so still it almost stifles me, and yet the leaves are rustling far and near from ripe fruit falling down from every tree.

Do not disturb this feast-day of the earth, this harvest which she gathers for her own; she only reaps today in silent mirth the bounty which the sun's mild rays have blown.

THE INDIVIDUAL AND THE UNIVERSAL

(Im grossen ungeheuren Ozeane)

Hebbel's objective approach to truth, which proceeds from the universal to the particular, contrasts with the subjective approach of the Romanticists, who first sought truth within themselves and then projected it upon the exterior world.

If you, a droplet in the boundless ocean, turn in upon yourself, avoid the whirl of heaving life about you, to a pearl no wind shall shape you with tempestuous motion. No, open up your innermost emotion, in joy and suffering mingle with the flow of every undulating wave; and so you serve yourself and nature with devotion. And do not fear, thus in the world dispersed, to lose yourself, to lose your separate form; the passage to yourself leads through the whole. When you with every wine have stilled your thirst, the force to stand against the wildest storm will come to you from out your deepest soul.

THEODOR STORM (1817-1888)

Theodor Storm was born in the town of Husum on the west coast of SchleswigHolstein. His father was an attorney, and the family was comfortably prosper- 
ous. Storm studied law at Kiel and Berlin and, in 1842, returned home to set up a law practice and take an active part in the political and social life of the town. When Schleswig-Holstein was occupied by the Danes, he bitterly opposed annexation and was finally deprived of his license to practice. Therefore in 1853, he left for Berlin where he became an assistant judge. After the war between Prussia and Denmark, Storm returned to Husum as mayor.

The works of few poets before Storm were so deeply rooted in the mother soil as his. The background of his writings is the flat, rather bleak North Sea coast and the mood of much of his verse reflects the gray fog which hangs over this area through much of the year. The people about whom he writes are representative of the small-town middle class of Husum. Storm has two favorite themes, love and the transitoriness of life, of youth, of beauty. Since he had neither the pantheism of Hebbel nor an orthodox faith to sustain him, Storm saw death only as an irreparable and infinitely tragic loss. His realism is seen in his attention to the details of the world about him and in his insistence on factual accuracy. Most of his verse was written during the early part of his career, at a time when the influence of Romanticism was still strong.

\section{THE HEATH}

(Es ist so still: die Heide liegt)

In this poem the characteristics of Realism appear at their best. It is pure description in which the objects in the world about are presented for their own sakes rather than for their symbolic significance. It is a landscape seen through a personality, but the personality only gives form and unity to the scene. It does not intrude upon it.

It is so still, the moorland lies and basks in midday's glowing waves; a rosy, gleaming shimmer flies about the stones of ancient graves; the scent of flowers everywhere pervades the azure summer air.

The beetles scurry from their cells in golden coats of mail, the bees are hanging from the heatherbells and swaying lightly with the breeze; from out the thicket whirs a throng of larks and fills the air with song.

A humble cottage on the moor stands all alone; the farmer warms himself within the open door 
and watches with content the swarms

of bees. His son with branch and knife

sits carving out a willow fife.

Scarce trembling through the still repose

a village clock strikes out the noon;

the old man's eyes begin to close,

he dreams of honey harvest soon.

No sounds which make these times so rude

have entered yet this solitude.

\section{SONG OF THE GYPSY GIRL}

(Heute, nur heute)

In this song from his novelette, Immensee, Storm laments the transitoriness of beauty. The Gypsy girl who sings the verses appears only twice in the story, once in the fulness of her dark and passionate loveliness, later when both beauty and mind have gone.
Alas that my beauty
is just for today;
tomorrow, tomorrow
must all fade away!
Only this hour
are you my own;
oh, I shall perish
when I'm alone.

THE CITY

(Am grauen Strand, am grauen Meer)

This, the most famous of Storm's poems, is a description of his native city, Husum.

The strand is gray, and gray the sea

by which the city lies;

the fog weighs down on roof and tree

and through the silence roars the sea

its never changing cries.

No forest stirs, no birds in May

fly singing o'er the land;

the honking geese at end of day

beat through the autumn skies their way

and grass blows on the strand. 
And yet my heart holds firm to you, gray city by the sea;

the charm of youth, forever new, rests smiling still on you, on you, gray city by the sea.

MAY

\section{(Die Kinder haben die Veilchen gepflückt)}

The action of the children illustrates the attitude of the poet. He was as charmed as they by the tangible aspects of nature and was almost as little concerned as they with its symbolic or philosophical significance.

The children have picked all the violets, down where the old mill stands.

The spring is here, they hurry to get

it fast in their little hands.

JULY

(Klingt im Wind ein Wiegenlied)

A young sister-in-law of Storm, who was soon to have her first child, is compared to the fields which in July are displaying their productivity. The clipped, abbreviated sound of the lines, which omit several articles and begin and end with accented syllables, give the poem a distinctive rhythm which is quite different from the melodious smoothness characteristic of Romanticism.

Sounds in wind a lullaby, sun shines warmly from the sky, heavy ears bend down the corn, berries ripen on the thorn, fields with richest blessings teem lady, tell me what you dream.

\section{THE SEASHORE}

\section{(Ans Haff nun fliegt die Möwe)}

The realism of Storm has been called Poetic Realism because of the poetic atmosphere and mood which envelope his portraits and landscapes. The subjectivity of such a poem as this reveals his close connection with Romanticism. 
The gull now flies to the harbor, the reddening sun sinks low, the sea beyond the marshes reflects the evening glow.

Gray water-fowl are skimming the surface as they flee, as dreams the islands hover in mists upon the sea.

I hear the seething marshes' mysterious sounds again strange and lonesome bird cries so it has always been.

Once more a breath comes trembling, and then the breezes sleep, and one can hear the voices that move above the deep.

Gottfried Keller is known chiefly as a writer of short stories, but he is also one of the best poets of Realism. He was a native of Zurich, a city which, together with the surrounding farm lands and villages, became the setting for most of his works. Keller's writings are regional and as much a product of the life and landscape of northern Switzerland as Storm's are of Schleswig-Holstein. He at first wanted to become a painter, and it was only after ten years of fruitless effort to develop his talents in this field that Keller turned to literature. He then went to Heidelberg to study, was particularly influenced by the lectures of Ludwig Feuerbach, and became a convert to the latter's materialistic philosophy at about the time he began to write his first works. Later Keller studied in Berlin. Although he soon attracted attention in literary circles, it was not until the author was in his fifties that he began to receive popular recognition. In the meantime, he supported himself as clerk of the canton of Zurich, a position which he filled capably.

Although he has written sad and melancholy songs, Keller is in general an optimistic writer. His optimism is not a casual light-heartedness, but that of a man who has experienced difficult times, has had to renounce a great deal, has seen the deficiencies and petty meanness of humanity, but has nevertheless reached a satisfactory modus vivendi with the world about him. As a poet he is severely honest in portraying people and situations just as they appear to be. He does not idealize them, nor does he seek for inner truths. The portrayal of an experience is never more pretentious than the experience itself. His poetry is 
sometimes lacking in music and rhythm, but it is always refreshing in its genuineness and simplicity. There are few obvious adornments: few traditionally poetic words, phrases, or metaphors. Keller's poems occasionally reveal a quiet humor, and sometimes a didactic vein appears. There are not many love songs among his poems, and what there are contain no great passion. It is as a painter in words that he chiefly excels. Keller loved landscapes, detail, and color. Indeed, it might be said that he tried to achieve in verse what he was unsuccessful in capturing upon a canvas.

\section{SUMMER NIGHT}

(Es wallt das Korn weit in die Runde)

The poem illustrates Keller's inclination toward pure description. The action is secondary to the sounds, physical details, and the colors.

The grain is surging all around and as a sea it stretches wide, but underneath its waves are found no depths where horrid monsters hide. The flowers dream of wreaths to be and drink the stars' irradiant fire; your peaceful gleam, $O$ golden sea my soul consumes with fierce desire.

The verdant valleys of my home have kept this ancient custom still: when summer stars from heaven's dome and glow-worms shimmer from the hill a whispering, a waving seems to weave along a country lane. Then glitter night-time silver gleams of sickles through the golden grain.

For sturdy youths, by night concealed, have gathered on the country side to seek the newly-ripened field of one of those whose men have died, who have no husband now, nor son, nor hired hand to lend his might. They harvest till the field is done and joy has made their labor light. 
Now all the sheaves are bound at last and quickly placed to form a ring; how pleasantly the hours have passed, how like a game their laboring!

Within the ring they sing with joy and dance until the break of morn calls every never-weary boy to harvest other fields of corn.

\section{WINTER NIGHT}

(Nicht ein Flügelschlag ging durch die Welt)

The mermaid in the poem is not a true mermaid such as might appear in a Romantic poem. She is a powerful symbol of life which tries to free itself from the icy grasp of winter, or, to broaden the symbol, from the confining restrictions which fate imposes on the expression of life.

Not a wing-beat passed across the sky, sparkling snow lay silent and serene, not a cloud obscured the stars on high, on the rigid lake no wave was seen.

From the depth a tree rose toward the light, in the ice its crown was fronzen fast, up the branches climbed a water sprite, through the greenish ice she peered at last.

As I stood upon the glassy sheet, looking downward through the waters dim, I could see, close underneath my feet, all her snowy beauty, limb by limb.

In despair she groped from place to place, pressing on the hard roof overhead, I shall always see that darkened face, and it ever fills my heart with dread.

\section{ILLUSION AND TRUTH}

\section{(In Mittagsglut, auf des Gebirges Grat)}

This is one of Keller's early productions, most of which were written in a single burst of enthusiasm and inspiration when, after years of aimless striving to find himself, he suddenly discovered that he was a poet. The pessimism of the last stanza may reflect fearful doubts as to the genuineness of his new-found talent. 
In midday heat upon a mountain rise

I lay beneath the ancient firs alone

and slept, and dreamed until the day had flown

of wasted deeds and hopes which now are sighs.

Still drunk with sleep I opened late my eyes

and round me all was flame - each bush and stone,

the mountain's icy head and weathered bone -

a wheel of fire illumed the western skies.

And faster beat my pulse, my heart was glowing;

I thought the gleam to be the morning red,

the brilliance of the rising sun foreshowing.

But mountains sank away, asleep and dead;

the night arose with frosty, angry blowing,

and with the moon my heart's familiar dread.

TIME DOES NOT PASS

(Die Zeit geht nicht, sie stehet still)

Although the poem deals with an abstraction - the passing of men through time - Keller keeps close to tangible things and each stanza introduces a new concrete symbol for this abstract idea. Time is everything here, and the poet does not hope for immortality. $\mathrm{He}$ is happy only to have lived for a while in the "great and splendid world."

Time does not pass, it never moves, we traverse it each day;

it is a caravanserei

and there we pilgrims stay.

A something - shapeless, colorless, which only gains a form

as we appear, submerge again, and melt into the storm.

A drop of morning dew reflects the radiance of the sun;

a day may be a string of pearls, a century be none.

An empty page is time on which each man must quickly write with his own blood until the stream has driven him from sight. 
To you, $\mathrm{O}$ great and splendid world, superlatively fair

I, too, shall write a note of love upon this parchment bare.

In thankfulness that I have bloomed within your crown of green, I'll not lament, but only praise the beauty I have seen.

CONRAD FERDINAND MEYER (1825-1898)

The career of Conrad Ferdinand Meyer shows considerable similarity to that of his countryman, Gottfried Keller. Meyer, too, was born in Zurich, considered becoming a painter, developed late as a poet, and became known principally as a writer of novelettes. There are other similarities between the two, but in most respects they were quite different. Meyer came from a rather wealthy patrician family and lived his whole life as a gentleman of leisure. As a result, his writings lack those deep roots in the land and in society which are particularly characteristic of poets of bourgeois social position and employment. Meyer suffered much of his life from a nervous instability which finally ended in insanity. His early years are marked by a dreamy irresolution which made it impossible for him to devote himself to any definite aim in life. $\mathrm{He}$ studied law for a short time, dallied with painting, made a desultory attempt to become a professor of French, and occasionally wrote mediocre verse. It was the momentous events connected with the restoration of the German Empire which, at forty-five years of age, provided him with the inspiration for his first outstanding work and called forth his true poetic talent. From that time on he was a careful meticulous artist, constantly reworking and improving his writings.

Meyer was a quiet man whose dignified appearance was a cloak for shyness and reticence. He was deeply religious, a Protestant of very conservative views. His character is reflected in his dispassionate and objective verse, for natural reserve prevented him from expressing his emotions directly in his poems, and most of his thoughts and feelings are presented by symbols. Symbolism penetrates all of his works. In them the whole of nature is filled with mysterious signs, for his world is penetrated with the spirit of God, and all exterior phenomena are the revelation of God's power. His verses are models of form, expression, and meter, but are, nevertheless, not extremely lyrical. He has the artist's appreciation for detailed description, but he seldom includes description for its own sake. To a greater extent than the other Realists he goes back into the past, the Middle Ages or classical antiquity, for his themes. 


\section{(Ein ärmlich düster brennend Fackelpaar, das Sturm)}

There has never been a satisfactory explanation advanced as to why the great poet Schiller was buried in the middle of the night in a hurried ceremony, attended by very few of his friends. In this poem Schiller represents all poets, who, although they may not receive the honors due them, will be mourned by the true spirit of humanity.

Two dismal, dimly burning torches which the storm and driving rain each moment threaten to put out, a waving pall, a coffin made of common pine with not a meagre wreath, no mourning funeral train, as though a hateful crime were hurriedly interred. The bearers hastened on. A stranger walked alone, enveloped in a broad and wildly beating cloak, behind the bier. The genius of mankind went there.

THE ROMAN FOUNTAIN

\section{(Aufsteigt der Strahl und fallend giesst)}

The poem describes the fountain at the Villa Borghese, which Meyer saw in 1858. The form of the poem is interesting. There are four feet to a line and four parts to the stanza. The first three parts treat in turn the three basins of the fountain, and the fourth summarizes the total action. The last line with only two feet is incomplete, as is also the action of the water.

The stream ascends and, falling, throws

its waters in the marble urn, which veils itself and overflows into a second bowl in turn.

The second swells and passes on into a third its seething crest; and all receive and give as one, and flow and rest.

\section{THE SOWER'S SONG}

\section{(Bemesst den Schritt! Bemesst den Schwung)}

Here Meyer expresses a determination to accept whatever comes as the gift of a beneficent Providence. The poem is atypical of the author in that he is not content to let his symbol, the wheat, speak for him, but makes a direct declaration of the central thought. 
Keep measured step and measured swing, the earth remains still long in spring. There falls a seed to die and rest; its rest is sweet, the seed is blessed. Here through the soil one makes its way; it, too, fares well, sweet is the day. And none but falls upon this sod, and each one falls as pleases God.

\section{AT HEAVEN'S GATE}

\section{(Mir träumt', ich komm ans Himmeltor)}

Here, as in many of the writings of Meyer, we find the theme of expiation. Sin can be forgiven, but only after penance, commensurate with the transgression, has been done.

I dreamed I came to heaven's door and found you there, my sweet; you lingered by the spring before the gate and washed your feet.

You washed and washed your feet, though they were gleaming white, and then began in haste, without delay, your endless task again.

I asked, "Why are you bathing so, and tell me why you weep?"

You spoke, "With you in dust below

I trod the dust so deep."

\section{SUNDAYS}

(Ich liebe, Nymphe, deine keusche Flut)

Most Swiss poets have been nature poets and, when one considers the natural beauties around Zurich, it is not surprising that Meyer should have devoted much of his verse to descriptions of the lakes, forests, and mountains which he saw on his Sunday walks. But the poem contains more than a description of a forest pool. Meyer sees himself in the pool: his shyness in boisterous company, his lack of youthful love affairs, his inclination toward solitude. Although the poet tries to keep the pool unsullied from contact with the noisy crowd, he scarcely conceals his regret for the life he is missing. 
I love, fair numph, your pure and virgin flood that coolly rests within the deepest wood. You mirror neither town nor mountain snow, but shimmer back the heaven's changing glow. Your animated visage must impart all that which passes in your childish heart, and, as its laughter brightens or grows dim, it tells to me your every mood and whim.

The skiff, concealed in reeds along the shore, is anchored fast by charms and magic lore. No drunken crowd has ever found it there, no panting maid with wildly streaming hair, pursued by rude admirers and distressed, has sat beside your looking-glass to rest. No torches' flame has flickered o'er this pool and glowed above your forehead, smooth and cool.

Hear! Voices through the wood! A boisterous cry, a shrieking, shouting! Boorish herd, pass by!

Shame on you, echo. Why must you repeat this loudly hooted ballad of the street? The lustre of your eyes, $\mathrm{O}$ nymph, conceal and deeper in the dusky forest steal. I turned in anger toward the noisy band and ordered them away with upraised hand.

"No closer!" In the forest then was peace; the tumult in a tavern found release. Unsullied you remained in azure gowned with green of forest twilight all around. The sun has meanwhile vanished from the skies; how sweet in every leaf the silence lies. In odors of the pines and shadows deep well guarded by my glance you fall asleep. 


\section{THE MODERN POETS}

The complete materialism of the end of the nineteenth century found its literary expression in the movement known as Naturalism. The duty of the poet, according to the theory of Naturalism, was not to create works of art, but merely to reproduce material reality. And this reality was an ugly one, for most of the Naturalists were interested in social reform and wished to expose the seamy side of life so that corrective measures might be taken. In the last analysis Naturalism did not aspire really to improve man, but only to make him more comfortable. The movement brought forth significant works in the drama and the novel, but nothing of lasting importance in poetry. Naturalism as a specific literary phenomenon was of short duration and was on the decline even at the turn of the century. It was not materialism, but the reaction to materialism, which exerted the stronger influence upon the literature of the early twentieth century.

A literature based on ugliness rather than beauty, a philosophy which taught that the highest human endeavor was the improving of the material situation of man, a theory of literature which placed the poet on a level with a photographer - all were equally repugnant to the majority of the modern poets. Some, like Nietzsche, while repudiating materialism, built upon it to achieve a higher and more positive approach to life and literature. Others turned away completely from materialism and sought for new idealistic values. By the second decade of the twentieth century, this search had become a desperate one, for while aspiring to something higher, the poets felt the solid ground beneath them disappearing. Materialism, the growth of which had been stimulated by science, was being destroyed by science. Riemann's theory of curved space, Planck's quantum theory, and Einstein's theory of relativity were only the first of a long series of scientific speculations which disrupted long-standing concepts of the material world. The law of the indestructibility of matter was discarded, and it began to appear that matter as such had no existence at all, that the universe was nothing more than waves of energy. The traditional conceptions of time and space were likewise found wanting, and the once inviolable law of cause and effect had deteriorated to mere mathematical probability. To the young intellectual it seemed as if he had sacrificed God for matter, only to have the latter disintegrate before his eyes. He saw himself confronted with chaos, or even worse, a great void in which existence was only a momentary suspension in an infinite emptiness. "Something horrible has happened to the reality of occidental man," writes the 
Existentialist Karl Jaspers, "a disintegration of all authority, the radical disillusionment of a haughty confidence in reason, a dissolving of ties which seems to make anything possible. The manoeuvering of the old words appears like a mere veil which conceals from our fearful eyes the forces of chaos that are about to burst in upon us. Such words have no other power than to continue the old deception for yet a while." It was necessary to find something absolute to take the place of the material world which had been lost. And this search led each man alone into the depth of his own soul where, if anywhere, substance might be found. Or, if there were no substance, perhaps at least an attitude might be obtained which would protect the individual from complete annihilation. The apparent flight from reality which characterizes much of twentiethcentury verse was actually a search for the true reality behind the mask of sensory phenomena.

\section{FRIEDRICH NIETZSCHE (1844-1900)}

The most ambitious attempt to erect a new structure on what appeared to be the ruins of Christian culture was made by that herald of the twentieth century, Friedrich Nietzsche. He was born in the town of Röcken, in upper Saxony, and was probably of Slavic extraction. He studied philology at the Universities of Bonn and Leipzig, and at the age of twenty-four was appointed professor of classical philology at the University of Basel in Switzerland. Nietzsche was a competent scholar in his field, but his main interest was the problem of modern man. He treated the modern dilemma in a long series of philosophical works which include such controversial books as Human, All Too Human, Thus Spake Zarathustra, Beyond Good And Evil, and The Geneology Of Morals.

Nietzsche accepts the materialistic view of man as a creature of heredity and environment. But he detects in him the same strong urge toward further development which is present in other plant and animal life. For man is not the ultimate in creation, but only a step in the evolutionary ladder. True man, the superman, is yet to come. However, an environment suitable for further evolution needs to be created. Christian morality with its emphasis on humbleness and brotherly love favors the weak at the expense of the strong, and so upsets the natural law of the survival of the fittest, upon which evolutionary progress depends. So, too, does democracy, a political system by which the mediocre have banded together to keep down the exceptional. According to Nietzsche, both Christianity and democracy stand in the way of human development.

These ideas form a background for Nietzsche's poems, but seldom appear in them. In his verse he solicits understanding for the man who has retired into remote solitude to look honestly and fearlessly into the great void of the cultural vacuum. The singer of his songs is attempting to find a true and optimistic goal for humanity which will raise it above the shallow life of the time. The poet will have nothing to do with illusions, self-deception, or complacency. $\mathrm{He}$ 
wishes to light the spark which will drive men onward. The language of Nietzsche's verse is powerful and lucid, with none of the diffuseness and vagueness which he decried. His poems are distinguished by vital rhythmical qualities and melodious lyrical expression.

\section{ECCE HOMO}

(Ja! Ich weiss, woher ich stamme)

The poem expresses in dynamic language the titanic striving of man, who illuminates and destroys what he touches as he presses forward toward absolute knowledge.

Yes, I know from whence I came.

Unappeasable as flame,

I consume myself entire.

What I touch illumes and flashes, what I leave has turned to ashes: surely I am flame and fire.

VENICE

(An der Brücke stand)

The impression which Venice had made upon Nietzsche may be judged by the remarks in his book, Ecce Homo, which directly precede this poem. "When I seek for another word for music," he writes, "I can think only of the word Venice. I can make no distinction between tears and music."

By the bridge I stood

lately in brownish night.

Distant singing came:

dripping with gold it swelled

over the trembling surface away -

music, gondolas, lights -

drunken it floated along in the dusk.

And my soul, a quivering lyre, sang, invisibly touched, softly a song of the gondoliers, trembling with secret ecstasy.

Who was listening then? 


\title{
(O Mensch! Gib acht)
}

The song is sung at the end of the festival of joy in Thus Spake Zarathustra. It is an exuberant affirmation of joyous life as an end in itself. Joy is rich and includes all things.

\author{
Hear man! It seems \\ a voice from deepest midnight streams: \\ "I was asleep - \\ now have I wakened from my dreams. \\ The world is deep, \\ and deeper than the daylight deems. \\ Deep is its woe, \\ and joy more deep than grief can be. \\ Woe utters: 'Go,' \\ but joy demands eternity; \\ seeks ever deep eternity."
}

\section{THE SUN SINKS}

(Nicht lange durstest du noch)

The poem is one of the Dionysus-dithyrambs which Zarathustra, the advocate of the enjoyment of sensual pleasure, sings to himself to make his last solitude more endurable. One of Nietzsche's objections to Christianity was that it upset the natural balance of man by its restrictions upon sensual pleasures.

\section{1}

You shall not thirst now much longer, my burning heart.

A promise is in the air;

from unknown mouths I feel a breath, refreshing coolness comes.

My sun stood hot above me at noonday: greetings to you who are coming, you sudden breezes, you cooling spirits of afternoon.

The wind moves strangely and purely. Does not the night with furtive glance alluringly tempt me? Be strong, my valiant heart; ask not "Why?" 
Day of my life, the sun is sinking. Already the polished flood is gilded.

Warm breathes the crag; was happiness taking his nap there at midday? In greenish lights happiness gleams up the brown abyss.

Day of my life, evening approaches.

Dimly your eyes glow in the twilight; now well forth the dew's droplets of tears;

the purple of your love runs silent over snowy seas, your last reluctant ecstasy.

3

Golden merriment, come, sweetest and strangest foretaste of death. Have I run my course too swiftly? Only now when my foot is weary does your glance overtake me, does your joy overtake me.

Round me only waves and play.

What was oppressive sank in blue forgetfulness idly stands now my skiff. It has forgotten storm and passage, wish and hoping have drowned; smooth lie the soul and the sea.

Sevenfold solitude! I never have felt sweet certainty nearer, the sun's glances warmer; does not the ice still glow on my summit? Silver, light, a fish outward is floating my skiff... 
(Nicht mehr zurück? Und nicht hinan)

The only hope of the wanderer is that he can continue to mount upward, for the so-called realities of life - the world, mankind, and death - are only his shadow. And as he climbs he has at least his path and the rising sun.

I can't go back? And not ahead?

No path a mountain goat could thread?

I'll wait then here and seize and prize what I can hold with hands and eyes.

Five feet of earth, the dawn, and breath; below me: man, the world, and death.

Stefan George was born in Bingen, the son of a well-to-do landowner. $\mathrm{He}$ decided at an early age to become a poet, and made no attempt to prepare himself for any other profession. After several semesters at the University of Berlin came a period of travel which took him to England, France, Austria, Spain, and Italy. When he returned to Germany he lived mainly in Berlin, Munich, and Heidelberg. When the National Socialists came to power, he moved to Switzerland.

George's reaction to the materialism of the times was to separate himself from the world about him and, with a selected group of disciples, withdraw into the seclusion of art for art's sake. The George group cut itself off as far as possible from the contemporary scene. Their sole mission was to revitalize poetry, to give it a new purity, a perfection of form, a severe clarity of language. The ideal of life which George set for himself and his followers was similar to his ideal of verse. He believed in a strictly controlled life, in which soul, mind, and body are forced into a harmonious unity of cooperation. The "third humanism," as George's doctrines are sometimes called, dispenses with the transcendental God and places divinity only in man himself. Man alone is significant, and nature is important only in its ministry to man. George was severely ascetic and hostile to the Dionysian element which Nietzsche insisted was an integral part of man.

The strongest influence upon George's verse was exerted by the French Symbolists whom he met in Paris in 1889. With them, he proclaims a poetry of mood rather than thought - a mood which is communicated for the most part through form. However, unlike the Symbolists, George insists upon regular rhythmical patterns and a definite musical quality. In his verse can be seen an 
intense preoccupation with the choice of words, a rejection of the current vocabulary, and a preference for words not in normal usage. This is part of a conscious attempt to preserve in verse an air of aloofness from actual life. George's language is extremely concentrated and compact. He avoids meaningless and colorless words, such as prepositions, articles and conjunctions, and expresses his central thought or mood almost exclusively through symbols. These latter are usually obvious, but sometimes are not.

George did not wish to become a popular poet and has not become one. However, the small group to which his verse has appealed is increasing, and now, fifty years after the publication of most of his works, he is read much more than at any time during his life.

\section{COME TO THE PARK}

(Komm in den totgesagten park und schau)

These are the opening verses of George's collection, The Year Of The Soul, and the landscape described is that which serves as a background for the struggles of the soul in the poems which follow. Like the park, the soul of the poet has only enough flowers in it to remind him of the summer that is passed.

Come to the park now left for dead and view the shimmer of a distant, smiling strand the gleaming of the clouds' surprising blue reflected on the pools and paths of sand.

Take there the gentle gray and there the yellow of box-wood and of birch. The wind is mellow, and tardy roses still are red, though fading, so take them for the autumn wreath you're braiding.

These last remaining asters, pluck them all; the purple fruit upon the tangled vine, and what is left of living green entwine together lightly to the face of fall.

\section{THE HILLSIDE WHERE WE WANDER LIES IN SHADOWS}

(Der hügel wo wir wandeln liegt im schatten)

George's symbolism may be interpreted as follows. The life through which we wander is a twilight which obscures our goals and much of human activity is therefore as purposeless as the aimless flight of moths. But nature in kindness will soon send death to end our pain. 
The hillside where we wander lies in shadows, while that one over there still weaves in light; the moon above its green and tender meadows still hovers as a wayward cloud of white.

The streets which point far off are slowly paling, the wanderers are stopped by whispered sighs. Is it a hidden water's hushed bewailing, or does a sleeping bird sing lullabies?

Two moths upon the meadow prematurely pursue each other past the grassy lane, and bush and blossom silently and surely prepare the scent of evening for our pain.

\section{PATH OF GOD TO US IS OPENED}

(Gottes pfad ist uns geweitet)

In the collection of verse, The Star Of The Covenant, George castigates in turn the various cultural evils of society. This poem, a battle song for his little group of followers, is the closing chorus of the work.

Path of God to us is opened, land of God for us decreed, war of God in us is kindled, crown of God by us perceived.

Peace of God is in our hearts, strength of God is in our breasts, wrath of God is on our foreheads, flame of God is on our lips. Bond of God has now enclosed us, flash of God through us has grown wealth of God is poured around us, joy of God for us is blown.

MY CHILD CAME HOME

\section{(Mein kind kam heim)}

The poem is from the cycle, The Seventh Ring, the central figure of which is Maximin, a youth whom George had known. The poet sees in the physical beauty of Maximin human perfection and fulfilment, and praises him as a god come down to earth. 
My child came home.

The seawind still is blowing in his hair.

His step still weighs

alarm endured and youthful wanderlust.

By salty sprays

the brown enamel of his cheek is burned:

fruit early ripe

in savage scent and fire of foreign suns.

His look is grave

from mysteries which I have never known, and lightly veiled, for he has come from spring into our cold.

So openly

the bud expanded I was almost shy, and turned away

my lips to which he bent to get a kiss.

My arms embrace

what quite unmoved by me to other worlds

has bloomed and grown -

my own, and yet so endlessly remote.

\section{WINDOWS WHERE I ONCE WITH YOU}

(Fenster wo ich einst mit dir)

Also from The Seventh Ring, this poem is very likely a poetic description of the death of Maximin, who died some two years after George had made his acquaintaince.

Windows, where I once with you watched the evening coutryside, shine with unfamiliar light.

From the gate the path still runs where you stood and never turned; then you started down the hill.

At the bend the moonlight gleamed on your pallid face once more... yet it was too late to call.

Darkness, silence, rigid air sink as then about the house; all my joy has gone with you. 
The works of Hugo von Hofmannsthal are among the first in which the disintegration of the material world becomes apparent. Hofmannsthal was born in Vienna, of rich parents. He studied first law, then Romance philology, with the intention of entering into an academic career, but soon decided to devote himself exclusively to literature. He lived all of his life in or near Vienna, wrote poetry, dramas, and librettos for the operas of Richard Strauss, and was instrumental, with Max Reinhardt, in founding the Salzburg festival.

Hofmannsthal began to write at an early age, and had reached maturity as a poet before he was twenty. Nearly all of his lyric poetry was composed between his seventeenth and his twenty-third year. His verse is that of a highly cultured and extremely sensitive aesthete. It reveals a love of rich and remote beauty, a complete detachment from everyday existence, and an oppressive but lyrical melancholy. Hofmannsthal shows an insight into human consciousness which is surprising in one so young. With expert skill he bares not only his own soul but also those of the various creatures of his imagination. He does not attempt primarily to convey ideas, but rather to create moods and to charm the emotions. However, his poetry is not vague and illusive, for his moods and emotions are almost always associated with simple and tangible symbols. Hofmannsthal's favorite themes are the transcience of existence, the fleeting encounters and the loneliness of life, and the growth of new generations into an inscrutable future.

\section{EARLY SPRING}

\section{(Es läuft der Frühlingswind)}

The wind has participated in sorrow and passion, falling blossoms and laughter, music and sunsets, and contains the essence of these experiences in its breath. It is a symbol of the coexistence in time and space of all things.

The spring wind blows through barren trees, strange things are those which fill its breeze.

It has gently swayed where tears were, and care, and lovingly played in tousled hair.

It scattered the blossoms along the road and cooled the bosoms that warmly glowed. 
Lips in laughter
it kissed as it passed,
meadows soon after
woke to its blast.

Through the flute it fled as a sobbing cry, and the evening red it touched and flew by.

It silently hurried through whispering halls and harried and worried the lamps on the walls.

The spring wind blows through barren trees strange things are those which fill its breeze.

Through colonnades of barren trees drives its breeze pallid shades.

And the scent it brought in flight from whence it came since yesterday night.

\section{(Und Kinder wachsen auf mit tiefen Augen)}

The transitoriness of life, the purposelessness of all existence, and the loneliness of the individual - the three great themes of the turn of the century - are described here in melancholy, rather than tragic, tones. Hofmannsthal can find no solution to the problems which these themes present, unless it is the sympathy which one man can sometimes offer to another.

And children everywhere with earnest eyes, that know not what they see, grow up and die, and all men go their many, separate ways. 
And bitter fruits grow sweet and beautify, and fall by night as dead birds to the ground, and, after days, they spoil where they lie.

And ever blows the wind, we hear the sound of words, and echo many as we pass; with joy we leap, with weariness are bound.

And roads traverse the forest and the grass, and towns with lights and ponds are here and there, and withered things that menace and harass.

Why were they so created, for they bear no likeness each to each, though manifold? And why should laughter change to tears and care?

What are these games to us, as we behold ourselves full grown and ever more alone, and straying aimlessly till we are old?

What matters all we've seen of lands and foam? And yet, who says, "Good evening," utters words which drip with reverie and sorrows's tone as heavy honey from the honey comb.

\section{POEM IN TERZA RIMA}

(Noch spür ich ihren Atem auf den Wangen)

The poem treats the strange nature of life. It is so ephemeral that one can seize no day or moment, so fleeting that the young child is already in the process of dying, so tenacious that the poet can still feel the presence of those long dead.

I still can feel its breath upon my face: how can it be that this so recent day is gone, forever gone, without a trace?

This is a thing beyond our fully knowing, and much too fearful even for dismay: that all is gliding by us, ever going.

And that my very self, unhemmed and free, came hither, from a little infant flowing, a beast would seem as mute and strange to me. 
That I a hundred years ago was there and that my fathers, buried though they be, are just as close to me as is my hair,

are part of me as is my very hair.

\section{SOME INDEED BELOW THE DECK MUST PERISH}

(Manche freilich müssen drunten sterben)

The interdependence of high and low, of present and past, makes each man an indispensable link in the chain of existence and gives significance to his being.

Some indeed below the deck must perish, where the heavy oars of galleys hasten, others live above beside the tiller, learn of bird-flight and of starlit heavens.

Some must lie with heavy limbs forever by the tangled roots of life's disorder, while for others seats are readied with the sibylls, queenly seers, and they sit at ease and cheerful, light of heart and graceful handed.

Yet from burdened lives a shadow rises to obscure the lives of others, light hearts ever linked to heavy as to air and earth around them.

Weariness of quite forgotten people weighs without relief upon my eyelids, and I cannot free my frightened spirit from the silent fall of distant planets.

Many fates with mine are interwoven, being merges each into the other, and my share is more than this existence with its slender flame and narrow lyre.

RAINER MARIA RILKE (1875-1926)

Rilke's flight from the contemporary scene was neither to the Hellenism of George nor to the Romantic fancy of Hofmannsthal, but to mysticism. Much 
of his work is devoted to a search for a poetic conception of God and of His relation to man and nature, a search which led him first to nature and then to himself. Many of Rilke's poems are expressions of the author's attempt to immerse his personality in rocks and trees and animals, and make them reveal in verse the true essence of their being. He wished to extract the divinity which is hidden in all things.

Rilke was born in Prague of German parents, attended first a military school, and later the universities of Prague, Munich, and Berlin, where he studied literature and art history. A period of travel in Italy and Russia was followed by a stay at an art colony near Bremen, where he met and soon afterwards married Clara Westhoff, a sculptress. Financial difficulties led to an early separation from his wife, and Rilke went to Paris, where he remained until the outbreak of the First World War. During a part of this time he was a secretary and companion to the sculptor, Rodin. After a short term of military service he began a wandering life which included residences in Austria, Germany, Italy, and finally Switzerland.

The extreme sensitivity which made it impossible for Rilke to make a place for himself in organized society is apparent in his verse. Coupled with a rare musical power over words, it enabled him to echo the rustle of trees, the rushing of water, the awakening of spring as few poets have done, and let him express the opposing feelings of solitude and relatedness of modern man in universal tones. Rilke was a master of the techniques of form and, although his poetic expression is carefully controlled, form and content are so skillfully matched that there is no impression of strain. Much of his verse is symbolic. The meanings of his symbols are not always apparent, but they aid in creating expressive and definite moods.

\section{SOLITUDE}

\section{(Du meine heilige Einsamkeit)}

Rilke knew what it meant to sacrifice human desires to his muse. He gave up his family, his wife, and his daughter so that he might become a poet. Run-on lines and the rhyming of prepositions are characteristic of Rilke's verse.

Oh thou my sacred solitude, thou art as rich and clean and wide as blooming fields of flowers.

Oh thou most holy quietude make fast the golden doors, outside of which desire towers. 
(Reitet der Ritter in schwarzem Stahl)

The poet sees death, not as something which comes to us from without, but as an essential part of our being. Rilke's fondness for alliteration is seen in such a line as "of a strange sword spring."

The knight rides forth in sombre mail heeding the world's glad call.

And there is the day and the valley and all and the friend and the foe and the feast in the hall and May and the maid and the wood and the grail, and God himself in image tall stands enshrined in every wall.

Yet in the armor of the knight, behind the chain's dark links, Death fretfully crouches, and thinks and thinks:

When in the turbulent fight

will the tempered edge

of a strange sword spring

over this iron hedge, a freeing sword that shall bring release from this cell which has held me fast, so I can stretch myself at last in the light of day and sing and play.

\section{AUTUMN DAY}

(Herr: es ist Zeit. Der Sommer war sehr gross)

The autumn day is a symbol of approaching death. All of Rilke's interpretations of death set it in the midst of life. It is not a conclusion of existence, but is placed upon the same plane as other experiences of life.

Lord, it is time. Summer was warm and long. Lay down your shadow on the sundial's face, on fields and meadows let the winds blow strong.

Command the last fruits ripen on the vine; allow them still two friendly southern days, force them to completion now, and raise the final sweetness in the heavy wine. 
Who has no house now, builds him one no more.

Who is alone now, long will so remain, will wake, will read, will write long letters, or will wander restless forth, and home again when leaves are dashed along the empty lane.

\section{AUTUMN}

(Die Blätter fallen, fallen wie von weit)

The poem describes the isolation of modern man, whose universe has lost its stability and is falling into chaos. Only in his belief in divinity can he find security.

The leaves are falling, falling as from faroff distant gardens withering in the sky. They fall to us with sad, negating miens.

And in the night the heavy earth careens into deep solitude from every star.

We all are falling. This right hand must fall. And look about you; it is everywhere, this constant downward urge. Yet One is there whose gentle hands control the fall of all.

\section{ON THE BRINK OF NIGHT}

\section{(Meine Stube und diese Weite)}

The souls of the inanimate objects of nature are awakened by the song of the poet which seeps down through matter to the center of creation.

My room and this broad expanse, One awake o'er the darkening land.

I am a string to dance, tightly spanned

over thundering resonance.

Things are violin bodies, full of dark imprecations; therein dreams woman's weeping, therein stirs restlessly sleeping the anger of whole generations.... 


\author{
I shiver \\ with a silver sound, and play: \\ then does all under me quiver, \\ and what in things goes astray \\ strives now toward the light of day, \\ that from my dancing song, \\ around which the heavens throng, \\ through fissures of languishing walls \\ into ancient cavernous halls \\ ceaselessly falls.
}

\title{
SONG OF THE SEA
}

\section{(Uraltes Wehn vom Meer)}

The poem was written on the island of Capri. The wind of the sea represents all of the powerful, primitive forces of life and nature against which Rilke (the fig tree) can hardly stand. The German word for fig also means timid or cowardly.

Age-old breath of the sea, sea-wind by night:

you do not come to me, too swift is your flight; the watcher scarce knows how he may oppose the old breath of the sea, which blows as against primal rock, tearing along in its race sheer space.

The fig tree yields to your shock, bending in the moonlight up there on the height.

\section{Selections From SONNETS TO OR PHEUS}

The fifty-five sonnets to Orpheus were written in a single burst of creative activity. The first twenty-six were completed in three days without, as Rilke reports, "one word's being in doubt or needing to be altered." Orpheus, a symbol of the poets of all ages, mediates between life and death, past and present, and experiences all things and the whole of human history as a single, timeless event. In the sonnets Rilke portrays various aspects of this one event. 
There rose a tree. Oh all-surpassing essence! Oh Orpheus sings! Oh tall tree in the ear! And all was still. Yet even in the silence did new beginning, growth, and change appear.

Creatures of stillness crowded from the clear awakened forest, came from lair and nest; but neither furtive craft nor cunning pressed them into breathless quiet, nor did fear, but hearing only. Bellow, scream, wild call seemed little in their hearts. And where before scarcely a hut had sheltered what came thronging,

a refuge out of dim, mysterious longing, with lowly entrance through a sagging door, you built them in their hearing temples tall.

II

Almost a child she was, and did appear from this one happiness of song and lyre, and brightly glittered through her spring attire, and made herself a bed within my ear.

And slept in me. Her sleep was everything. All trees that I had loved lay in my hand, far-away cities and near-by meadowland, and all the wonders life can ever bring.

She slept the world. You singing god and mild, how did you form her to have no desire to waken once before her endless dream?

Where is her death? Will you compose this theme before your song is ended and your lyre is still? She sinks away, but where? Almost a child.

\section{V}

Erect no monuments. Just let the roses each summer blossom in his memory. For it is Orpheus. His metamorphoses in this one and in that. We need not be concerned with other names. Once and for all, what sings is Orpheus. He comes and goes. 
Is it then not enough that his sweet call at times outlasts the fragrance of the rose?

Oh comprehend that he must disappear! Though he himself may dread the stern command. For while his words transcend existence here

he passes with them far beyond your gaze. The latticed lyre cannot ensnare his hand. And in complete transcending he obeys.

XIV

We see about us flower, fruit, and vine.

They tell not only summer's rich creation. From darkness mounts a gay-hued revelation, that has in it perhaps the envious shine

of those dead things that fertilize the earth. What do we know about the part they play?

It is their destiny, the fallow clay with their free dust to waken to new birth.

But do they do it gladly? Or do hordes of sullen slaves prepare the future fruits that rise reluctantly to us, their lords?

Are they the lords, who sleep beside the roots and grant us what their surplus never misses, this hybrid thing of silent strength and kisses?

\section{XIX}

Though the world alter as fast as cloud formation, home to the ageless at last falls all creation.

Over the change and the throng, freer and higher, echoes your primal song, god with the lyre.

Suffering we misunderstand, love is unlearned, and the breath of that which removes us in death nothing reveals.

Only the song o'er the land hallows and heals. 


\section{INDEX OF AUTHORS}

Brentano, Clemens 90

Claudius, Matthias 48

Dietmar von Aist 3

Eichendorff, Joseph von 98

Fleming, Paul 25

George, Stefan 146

Gerhardt, Paul 22

Goethe, Johann Wolfgang 57

Gryphius, Andreas 29

Günther, Johann Christian 39

Hebbel, Friedrich 126

Heine, Heinrich 112

Heinrich von Morungen 5

Hölderlin, Friedrich 79

Hölty, Ludwig 53

Hofmann von Hofmannswaldau, Christian 33

Hofmannsthal, Hugo von 150
Keller, Gottfried 133

Klopstock, Friedrich 44

Lenau, Nikolaus 117

Meyer, Conrad Ferdinand 137

Mörike, Eduard 121

Neidhart von Reuenthal 16

Nietzsche, Friedrich 142

Novalis (Friedrich von Hardenberg) 86

Platen, August von 109

Rilke, Rainer Maria 153

Rückert, Friedrich 105

Scheffler, Johann 31

Schiller, Friedrich 73

Storm, Theodor 129

Uhland, Ludwig 94

Walther von der Vogelweide 11

Wolfram von Eschenbach 9 



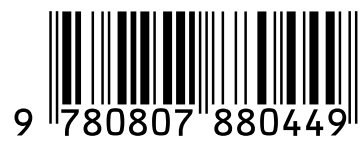

